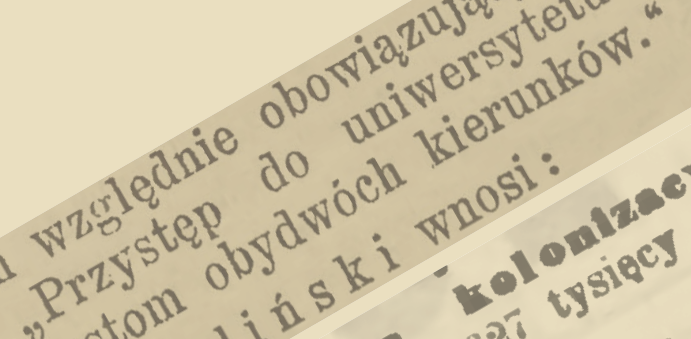

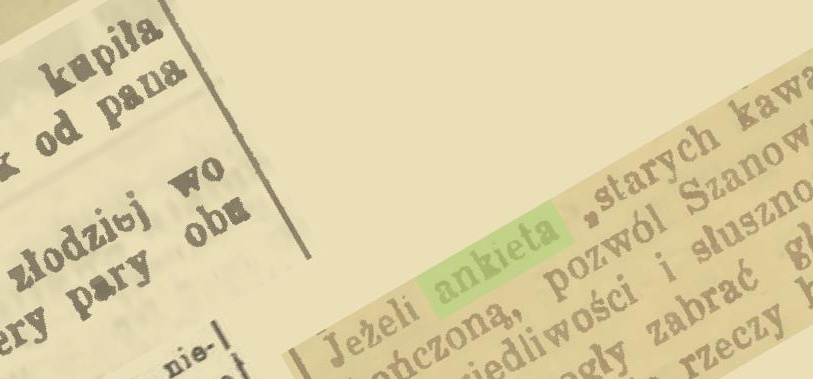

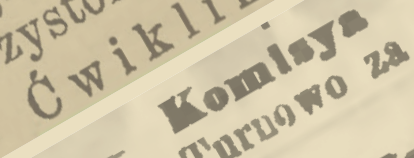

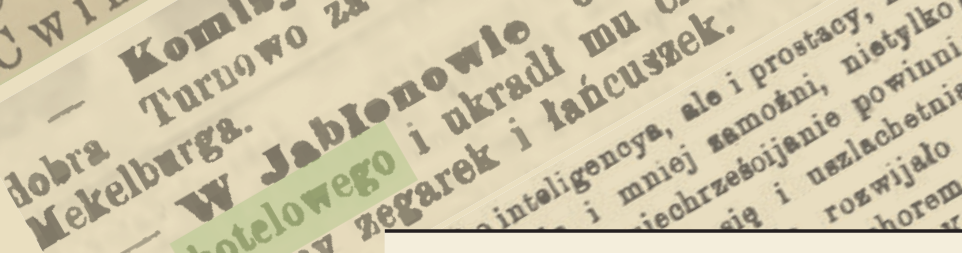
Jan Wawrzynczyk
Piotr Werchon
Lukasz Borchmann $+0290010105$

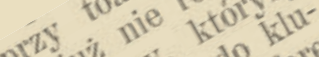
(1) juans a feren $^{2}$

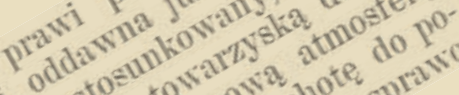

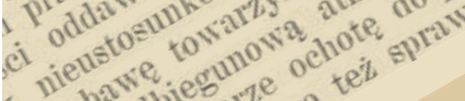

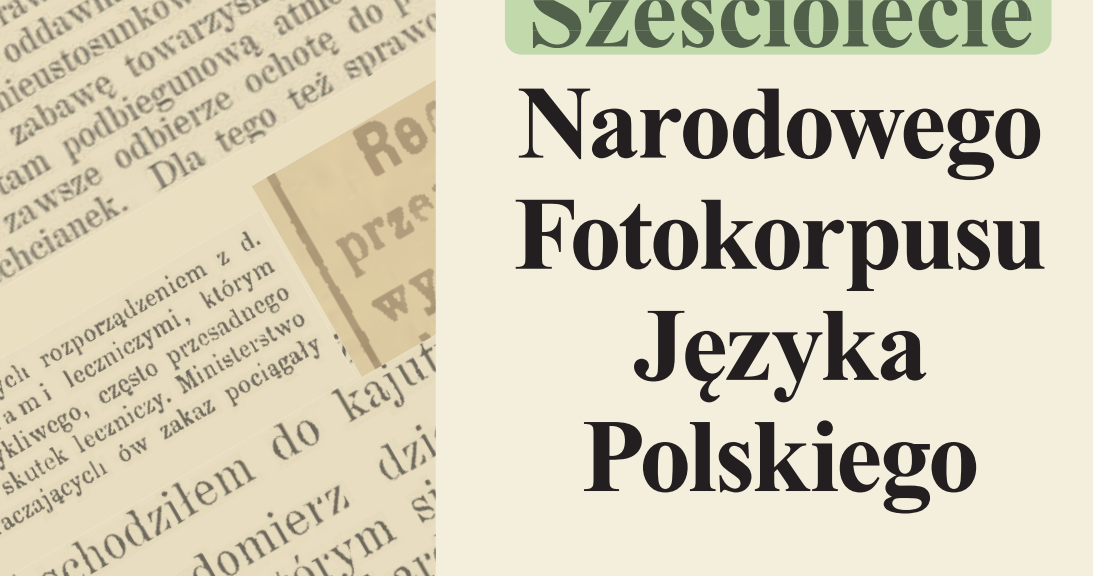

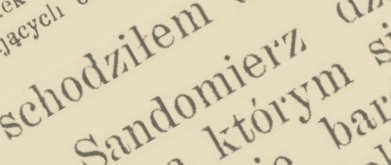

Sześciolecie Pat 15015 bal

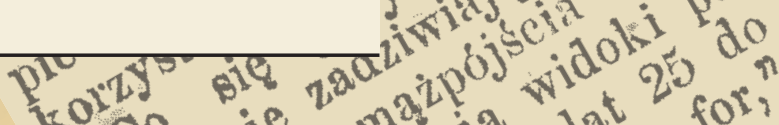
11.

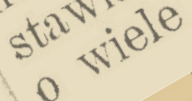
* * *

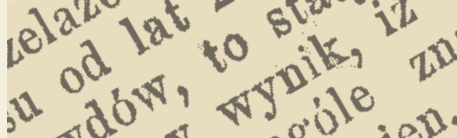
a 30 a 080010

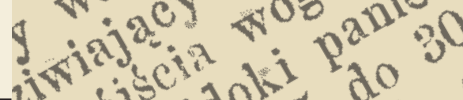

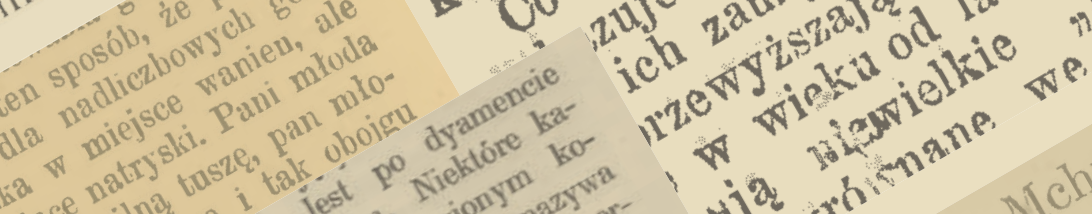

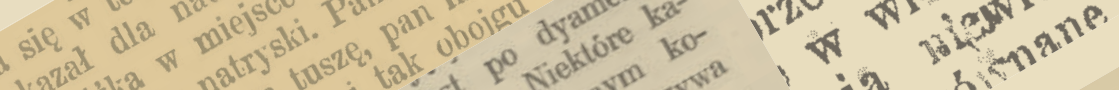

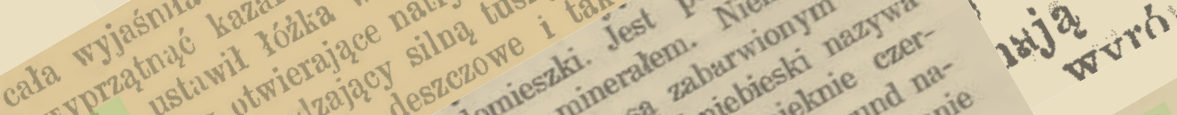




\section{Sześciolecie Narodowego Fotokorpusu Języka Polskiego}


Jan Wawrzyńczyk

Piotr Wierzchoń

Łukasz Borchmann

* * *

Sześciolecie

Narodowego

Fotokorpusu

Języka

Polskiego

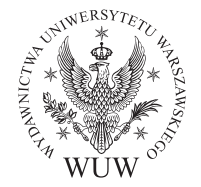


Recenzenci

Jolanta Mędelska-Guz

Katarzyna Wojan

Redaktor prowadzący

Katarzyna Bielawska-Drzewek

Redakcja

Magdalena Orczykowska

Korekta

Wydawca

Projekt okładki i stron tytułowych

Anna Gogolewska

Ilustracja na okładce

Fotocytaty $z$ NFJP

Skład i łamanie

Dariusz Górski

Publikacja dofinansowana ze środków Narodowego Programu Rozwoju Humanistyki

(1) NARODOWY PROGRAM
ROZWOJU HUMANISTYKI

(C) Copyright by Wydawnictwa Uniwersytetu Warszawskiego, Warszawa 2021

Jan Wawrzyńczyk ORCID 0000-0003-201 1-3240

Piotr Wierzchoń ORCID 0000-0002-7658-5362

Łukasz Borchmann ORCID 0000-0003-4409-8356

ISBN 978-83-235-4819-5 (druk)

ISBN 978-83-235-4827-0 (pdf online)

ISBN 978-83-235-4835-5 (e-pub)

ISBN 978-83-235-4843-0 (mobi)

Wydawnictwa Uniwersytetu Warszawskiego

00-838 Warszawa, ul. Prosta 69

e-mail:wuw@uw.edu.pl

księgarnia internetowa: www.wuw.pl

Wydanie 1, Warszawa 2021

Druk i oprawa

POZKAL 
Dokładność, gruntowność i jasność są kresem, do którego usiłowania każdego znakomitszego słownikarza zdążać powinny. August Bielowski, cytat ze Stownika jezyka polskiego S.B. Lindego 


\section{Spis treści}

Uwagi wstępne . . . . . . . . . . . . . . . . . . . . . . . . . . . . . . . . 9

Cel projektu . . . . . . . . . . . . . . . . . . . . . . 10

Podstawa metodologiczna . . . . . . . . . . . . . . . . . 10

Dotychczasowy dorobek ekscerpcyjny dla XX wieku . . . . . . . . . . . 11

Znaczenie nowych prac leksykograficznych . . . . . . . . . . . . 11

Struktura NFJP . . . . . . . . . . . . . . . . . . . . . . . . . . . . . 12

Kwestia komponentów latentnych informacji leksykograficznej w NFJP . . . . . 12

Przykłady informacji nieodzwierciedlonej w hasłowniku NFJP . . . . . . . . . 14

Czy NFJP dezinformuje? . . . . . . . . . . . . . . . . . . . . . . . 42

Bibliografia . . . . . . . . . . . . . . . . . . . . 44

Fotomateriały. Świadectwo danych z roku $1898 \ldots \ldots$. . . . . . . . . . 47 


\section{Uwagi wstępne}

Projekt o nazwie „Narodowy Fotokorpus Języka Polskiego” (dalej: NFJP) realizowany był od połowy roku 2014 do połowy roku 2020 dzięki wsparciu finansowemu udzielonemu w formie grantu przyznanego przez Ministra Nauki i Szkolnictwa Wyższego w ramach rządowego konkursu Narodowy Program Rozwoju Humanistyki. W stosownej umowie, zawartej między Ministerstwem a Uniwersytetem Warszawskim jako jednostką naukową prowadzącą ów grant, znajduje się informacja o podtytule projektu: „Fotodokumentacja słownictwa XX w.”.

Ogólnie, w celach marketingu naukowego przedsięwzięcie było już przedstawiane w kilku niewielkich publikacjach (por. Wawrzyńczyk, Wierzchoń 2016; Wawrzyńczyk 2017; Wawrzyńczyk, Wierzchoń 2017). Ma ono charakter unikatowy, jego celem była konstrukcja największego w dziejach leksykografii języka polskiego zbioru danych poświadczeń cytatowych (głównie zdaniowych, nierzadko wielozdaniowych) dla około 250000 haseł słownikowych, z jednego tylko stulecia, poświadczeń jednostek ujmowanych jako obiekty leksykograficzne zgodnie z kilkuwiekową tradycją, której istotnym składnikiem, jednym z fundamentów, jest 11 -tomowy Stownik jezyka polskiego, opracowany przez zespół pod kierunkiem Witolda Doroszewskiego (por. Doroszewski 1958-1969). Słownik ten, dziś traktowany powszechnie jako dzieło klasyczne, kapitalne, liczy około 125000 haseł.

Po sześciu latach pracy nad NFJP nadszedł czas na pewne etapowe podsumowanie naszych wysiłków i zarazem nakreślenie nowych zadań, nowych perspektyw, by uzyskane dotychczas wyniki można było implementować owocnie (i równocześnie autokrytycznie) w przyszłości.

Pryncypialną nowość w opracowaniu naszego ćwierćmilionowego zbioru haseł polszczyzny XX wieku stanowi forma podawcza: poświadczenia cytatowe prezentowane w NFJP, a umieszczone w najdostępniejszej bibliotece świata, czyli w internecie (na stronie: www.nfjp.pl). To nie ręcznie ekscerpowane wyimki z tekstów źródłowych, lecz fotocytaty, gwarantujące absolutną zgodność wyimka z jego źródłem drukowanym (ewentualnie, zupełnie wyjątkowo - rękopiśmiennym). Brak tej zgodności był i nadal bywa - w nowych słownikach, nietworzonych z zastosowaniem techniki fotoekscerpcji - 
przyczyną najrozmaitszych licznych błędów, zniekształceń, w tym powoływania do życia, wprowadzania do obiegu fikcyjnych bytów leksykograficznych, które w anglosaskiej literaturze krytycznej określa się mianem ghost words (por. w odniesieniu do opracowania: Doroszewski 1958-1969 pracę Wawrzyńczyk 2010 i Wawrzyńczyk 2016).

Zasada doboru haseł z ustalonego zbioru tekstów źródłowych do hasłownika NFJP - w jego części dwudziestowiecznej - jest elementarnie prosta: trafić do niego powinna każda jednostka nieobecna w dziele Władysława Kokowskiego, pierwszym polskim słowniku ortograficznym XX wieku (Kokowski 1903). W efekcie na podstawie kryterialnej bazy Władysława Kokowskiego sprzed niemal 120 lat powstała baza leksykalna o znacznej objętości, wykraczająca bardzo mocno, zarówno pod względem ilościowym, jak i jakościowym, poza którykolwiek słownik ogólny (czy to tak zwane narodowe, czy inne zasłużone dzieła) języka polskiego.

\section{Cel projektu}

Uzyskana baza ma - dzięki nadzwyczaj poważnej liczbie innowacyjnych w formie poświadczeń fotocytatowych - określone znaczenie dla badań nad zasobem i rozwojem słownictwa polszczyzny XX wieku. Każdy ekscerpt jest dokładnie zlokalizowany, to znaczy podaje się nazwę dokumentu, z którego pochodzi. Jednocześnie, obligatoryjnie, ekscerpty zostały dokładnie scharakteryzowane pod względem chronologizacyjnym, czyli odnotowuje się datę roczną ich wystąpienia w tekście.

Zaznaczyć należy, że dla pierwszej połowy XX wieku, w tym dla szczególnie doniosłego w aspekcie dziejo- i kulturotwórczym dwudziestolecia międzywojennego, rejestry leksyki są nader skąpe i ograniczają się do systematycznych ekscerpcji realizowanych przez zaledwie kilku badaczy, konstruktorów NFJP właśnie. Początki rejestracji regularnych sięgają epoki przedfotocytatograficznej, wyznaczają je dwie prace: Wawrzyńczyk 1987 i Wawrzyńczyk 1989. Skokowe zwielokrotnienie danych dwudziestowiecznych otwiera możliwość różnych zastosowań, prowadzenia badań morfologicznych, badań w zakresie kontaktów międzyjęzykowych na poziomie leksykalnym, badań w zakresie frazeologii (w najszerszym rozumieniu tego dziś już nieostrego terminu), analiz stylometrycznych itp.

\section{Podstawa metodologiczna}

W zakresie idei inicjującej masową ekscerpcję słownictwa XX wieku najwięcej ważą prace dokumentacyjne Jana Wawrzyńczyka (por. Bibliografia), które zaczęły się pojawiać regularnie od końca lat 80 . XX wieku. Istota tych prac polega na sięgnięciu do materiałów tekstowych, które (1) nigdy wcześniej nie były ekscerpowane pod kątem leksykograficznym bądź (2) ekscerpowane, wybierane do ekscerpcji były, ale wyrywkowo, bez jakiegokolwiek planu, niesystematycznie. 
Z kolei ramowa podstawa metodologiczna dla prac fotodokumentacyjnych przejęta zostaje z opracowań Piotra Wierzchonia, zwłaszcza z monografii: Wierzchoń 2008a. Realizacja tak szerokiego zadania nie byłaby możliwa bez wyboru odpowiedniej, niezbędnej tu teorii optymalizacyjnej w systemie zadaniowo-zasobowym (por. np. Węglarz 1981). System ten sprowadza się do jednoznacznego wyszczególnienia zasobów, zadań oraz czasu, w którym zadania te muszą zostać wykonane. Szczegółowe rozwiązania pozwalające na realizację tego przedsięwzięcia opracowane zostały wspólnie przez Łukasza Borchmanna i P. Wierzchonia.

\section{Dotychczasowy dorobek ekscerpcyjny dla XX wieku}

Odpowiednie dane szczegółowe zawiera Bibliografia umieszczona na s. 44-49 niniejszego tomu. Prezentuje ona zarówno prace okresu przedfotocytatograficznego dziejów leksykografii, jak i późniejsze, oparte na metodologii i technikach fotokorpusowych. Ze względu na znaczny przyrost publikacji z zakresu fotoleksykografii od 2008 roku można już mówić o narodzinach lingwistyki fotokorpusowej. Chcielibyśmy podkreślić, że jednym z czynników determinujących narodziny i szybki rozwój fotoleksykografii były osiągnięcia (i potknięcia, niekiedy bardzo przykre ${ }^{1}$, którym w ostatecznym rozrachunku przypisujemy wartość pozytywną) naszych poprzedników zajmujących się leksyką polską XX wieku; szczegóły bibliograficzne por. w: Wawrzyńczyk 1993; Wawrzyńczyk 1999; Wawrzyńczyk 2011.

\section{Znaczenie nowych prac leksykograficznych}

Przy radykalnie zakrojonej ekscerpcji ze źródeł tekstowych, które do dziś przez badaczy nie były jeszcze brane pod uwagę - z różnych powodów: i subiektywnych (niewystarczające kompetencje źródłoznawcze), i obiektywnych (brak dostępu do części zasobów bibliotecznych) - poznanie polszczyzny XX wieku jest obecnie możliwe na znacznie pełniejszą skalę. Mówić należy o tak wielkiej już kumulacji zupełnie nowych danych, że to poznanie na poziomie leksykalnym, derywacyjnym, w parametrach morfologicznych, ortograficznych, stylistycznych, frekwencyjnych, geograficznych itp. implikować będzie głęboką rewizję wielu dotychczasowych poglądów na język polski, także oczywiście w aspekcie diachronicznym, dynamicznym.

Zarazem uwzględnienie w stopniu dotychczas niespotykanym w ekscerptologii polonistyczno-językoznawczej źródeł prasowych i wprowadzenie do obiegu informacyjnego, nie tylko zresztą w kręgach lingwistycznych, dziesiątków, a wkrótce i setek, tysięcy wycinków prasowych - nierzadko dłuższych, całoakapitowych - oznacza znaczącą kumulację danych o charakterze pozalingwistycznym, encyklopedycznym,

\footnotetext{
${ }^{1}$ Z obszaru źródłoznawstwa tekstologicznego, krytyki wydań tekstów i ich doboru do ekscerpcji.
} 
odnoszących się do bogactwa nie tylko słów, ale też rzeczy oraz pojęć. NFJP uzyskuje przez to także określony wymiar czysto praktyczny, społeczny, ogólnokulturowy.

\section{Struktura NFJP}

Została zaprojektowana rozwojowo, dane pochodzące z okresu 1901-2000, które są efektem prac zaplanowanych w umowie o grant, stanowią tylko jeden segment konstrukcji naszego fotokorpusu. NFJP obejmuje poza tym okresy 1773-1800, 1801-1900 i 2001-2100. Tymczasem w odpowiednich miejscach strony internetowej udostępniamy z tych lat jedynie nieliczne, przypadkowe fotocytaty; poważna rozbudowa tych segmentów to sprawa kilku najbliższych lat.

\section{Kwestia komponentów latentnych ${ }^{2}$ informacji leksykograficznej w NFJP}

Zagadnienie dotyczy danych, których znalezienia nie umożliwia użytkownikom siatka haseł naszego ${ }^{3}$ fotokorpusu.

Grantodawca zaakceptował naszą propozycję struktury hasłownika. Ponieważ cały projekt jest dynamiczny, jego założenia będą modyfikowane i wzbogacane. Skoro pierwszy etap budowy fotokorpusu musiał zostać ograniczony chronologicznie do jednego stulecia, nie mógł, co zrozumiałe, obejmować zbyt wielu zadań cząstkowych. Siatka haseł obecnie jest pod względem formalnym pokrewna siatce haseł słownika Doroszewskiego, ale będzie ewoluować tak, aby występowały w niej wyrażenia hasłowe graficznie bardziej złożone, zawierające spacje wewnętrzne (por. Wawrzyńczyk 2020a). Będzie to modyfikacja, wprawdzie komplikująca prace nad NFJP, ale sprawi ona, że użytkownicy słownika uzyskają dostęp do informacji obecnie, w materiałach dokumentacyjnych stulecia 1901-2000, ukrytej wewnątrz poszczególnych artykułów hasłowych (w fotocytatach). Informacja ta jest znacznie przecież bogatsza, niż można by sądzić na podstawie samych wyrażeń hasłowych, to jest nagłówków odpowiednich artykułów. Odnosi się to zwłaszcza do tych artykułów, w których fotocytaty są obszerniejsze im więcej grafoform w danym cytacie, tym więcej dostarcza on informacji językowej i pozajęzykowej.

${ }^{2}$ Przymiotnik znany z prac biologicznych i psychologicznych, przenosimy go na teren leksykografii ze względu na jego wyrazistość znaczeniową i onomazjologiczną poręczność; por. Małek, Wawrzyńczyk 2010a.

${ }^{3}$ Kwestia owych komponentów jest poniekąd uniwersalna, dotyczy każdego większego zbioru danych leksykograficznych; por. m.in. Wawrzyńczyk 1995. Im większy słownik, tym większe prawdopodobieństwo występowania w nim informacji niejawnej w ilościach tak dużych, że pojawia się zjawisko kompensacji leksykograficznej, które bezwzględnie powinno zostać wyzyskane w celu wzbogacenia danych (por. Wawrzyńczyk 2016a; Wawrzyńczyk 2016b). 
Czego nie ujawnia „goły” hasłownik NFJP? Pytanie jest zasadnicze. Pomijając oczywisty fakt niewystępowania ${ }^{4} \mathrm{~W}$ nim haseł odnotowanych przez W. Kokowskiego (Kokowski 1903), zacznijmy od podstawowego w leksykologii podziału słownictwa na pospolite i własne.

Zgodnie z praktyką twórców fundamentalnego słownika Doroszewskiego NFJP ogranicza się na poziomie hasłownikograficznym zasadniczo do nazw apelatywnych, nie uwzględnia haseł onomastycznych - nazw własnych, osobowych, geograficznych i pozostałych kategorii onimicznych, choć jednocześnie owe kategorie leksyki są w obu tych słownikach reprezentowane bardzo szeroko, tyle że w cytatach. Na liście tego rodzaju jednostek, haseł potencjalnych w NFJP, znalazłyby się tysiące nazw (rodzimych i obcych, z najróżniejszych języków, przejętych do polszczyzny w transkrypcji, po takiej czy innej adaptacji graficznej): Ania, Baśka, Beatrycze, Bononia, Byron, Czechow, Dantyszek, Dworanowski, Frania, Giuliano, Hanuszkiewicz, Jim, Julian, Kopernik, Korynt, Lwów, Malczewski, Malwinka, Mania, Padwa, Palermo, Platówna, Preis, Przeździecki, Randon, Rzesza Niemiecka, Sołżenicyn, Stany Zjednoczone Ameryki Północnej, Szwajcaria, Tadzio, Teoś, USA, Wały Hetmańskie, Wisła itp. Grafoznaki te, nieuwidocznione w siatce haseł, odzwierciedlają dzięki słowu rzeczywistość, świat realny, pozajęzykowy z całym jego bogactwem, zróżnicowaniem, wielowarstwowością, a także historią - przez pryzmat języka polskiego. Podzbiór danych onomastycznych NFJP jest stosownie do tego tak bogaty, że obejmuje praktycznie niemal wszystkie gatunki onimów, nazewnictwa medialnego, muzycznego, nie wyłączając między innymi kosmicznego. Oto kilka tylko przykładów: Biblioteka Narodowa, Biuro Studiów Osadniczo-Przesiedleńczych, Celestia, Domek trzech dziewcząt, MChAT, Rada Naukowa dla Zagadnień Ziem Odzyskanych, Safeguard, Sojuz-19.

W przyszłości, w kolejnych etapach rozbudowy NFJP, wymienione wyżej hasła ukryte pojawią się w jego hasłowniku na równi z hasłami apelatywnymi wraz z odpowiednimi fotocytatami dokumentacyjnymi, już znanymi użytkownikom. Takie powtarzanie fotomateriałów NFJP, służące jego użytkownikom, nie jest oczywiście skazą korpusu 5 .

Przejdźmy teraz w taksonomicznym przeglądzie komponentów latentnych zasobów NFJP do centralnej kwestii informacji o charakterze lingwistycznym, kwestii jednostek syntaktycznie złożonych, niejednowyrazowych, z koniecznym zastrzeżeniem, że nie odnosi się ona do złożeń ze składnikiem zwrotnym się (jak bać się).

Rzecz dotyczy takich jednostek języka w rozumieniu Andrzeja Bogusławskiego (por. Bogusławski 1988), które na poziomie graficznym zawierają co najmniej jedną spację wewnętrzną. Jest to materiał odnoszony tradycyjnie do frazeologii, w słowniku

4 Jak np. przymiotnik rzeczownikowy, wyraz udokumentowany fotocytatowo w NFJP pod nierekursywny. Dane zawarte w NFJP, ale niedostępne w nim bezpośrednio „z winy Kokowskiego” to również bardzo cenny materiał dokumentacyjny, ze względu na formę (fotoświadectwa) niezbędny w procesie opracowywania historii leksyki dwudziestowiecza. Do kompletnego obrazu tej historii droga jeszcze daleka.

5 Naśladujemy w tym względzie słownik Doroszewskiego, w którym kilkakrotne wykorzystanie tego samego cytatu (niekiedy z modyfikacjami, kupiurami) jest zjawiskiem nierzadkim. 
Doroszewskiego podobnie jak i w NFJP praktycznie niemożliwy (z zupełnie marginalnymi statystycznie wyjątkami) do odszukania na poziomie hasłownikowym. U Doroszewskiego frazeologia została wyodrębniona graficznie w niektórych tylko artykułach hasłowych, w sumie jest jej niezbyt dużo, dzieło to w żadnym razie nie może zastąpić słownika frazeologicznego. W NFJP hasłownik również nie ujawnia związków zwyczajowo nazywanych frazeologicznymi. Ustalanie ich „kryjówek” to skomplikowane i czasochłonne zadanie. Zajmiemy się nim po roku 2020, trzeba będzie skontrolować wszystkie fotocytaty pod kątem obecności w nich jednostek języka z co najmniej jedną spacją wewnętrzną. Na dziś zlokalizowaliśmy - jako hasła potencjalne - około 20000 grafowyrażeń tego rodzaju. Nie jest to liczba ostateczna, szacujemy, że lista kompletna NJFP ze stulecia 1901-2000 może zawierać co najmniej 100000 „niejednowyrazowców"6.

\section{Przykłady informacji nieodzwierciedlonej w hasłowniku NFJP}

Przede wszystkim - odróżniamy dane zawarte w internetowym NFJP (pod adresem: www.nfjp.pl) od danych zawartych w zasobach niejawnych NFJP, danych gromadzonych w ogromnym e-magazynie z materiałami roboczymi, który jest jednocześnie czymś w rodzaju wielkiej ${ }^{7}$ hali produkcyjnej; z niej gotowe już produkty trafiają do sieciowego NFJP.

6 Tę liczbę można zestawić z dwiema następującymi wielkościami: (1) znane, cenne opracowanie Stanisława Bąby i Jarosława Liberka (Stownik frazeologiczny wspótczesnej polszczyzny, wyd. 1, Warszawa: Wydawnictwo Naukowe PWN, 2002) liczy ok. 4000 artykułów hasłowych i 15000 cytatów (transkrybowanych, czyli wypisanych ręcznie, co powoduje, że ich zgodność z oryginałem nie jest, nie może być stuprocentowa!); (2) przygotowywane do druku wznowienie, po gruntownych zmianach, cennego Wielkiego stownika frazeologicznego jezyka polskiego Piotra Müldnera-Nieckowskiego (Warszawa: Świat Książki, 2003) ma zawierać ok. 38000 artykułów-gniazd i 210000 jednostek, z cytatami, również wypisanymi ręcznie z tekstów źródłowych; tę informację kwantytatywną otrzymaliśmy od samego Autora dnia 3 VII 2020 r. Przywołane liczby nie są oczywiście porównywalne wprost, niemniej pokazują wyraźnie, jak wiele nowego dzieje się w „wielkoskalowej” leksykografii języka polskiego.

7 Przymiotniki ogromny, wielki nie są tu nadużyciem. Jeśli ktoś kliknie w sieciowym NFJP np. na hasło hotel czy hotelowy, to znajdzie tam tylko po jednym fotocytacie, tymczasem w zasobach niejawnych NFJP takich fotopoświadczeń na owe wyrazy mamy dziesiątki. W wypadku wielu innych haseł odnotowanych w sieciowym NFJP fotopoświadczeń zmagazynowanych, niedostępnych użytkownikom, są setki, a niekiedy wręcz nie setki, lecz setki tysięcy, a nawet miliony (tak!) fotocytatów. To dowód naszej mocy badawczej. Epoka „bigdatowa” w leksykografii języka polskiego została otwarta (por. Witas 2020). Zapewne potrzebny jest jeszcze jakiś czas, by wiedza o tym otwarciu się upowszechniła. Tak zwane zapóźnienie informacyjne w polskiej lingwistyce jest faktem. Już od 2014 r. zaczęły się regularnie ukazywać publikacje na temat NFJP. Trzy lata później wydano drukiem w Krakowie, nakładem Towarzystwa Miłośników Języka Polskiego, specjalne informatorium o elektronicznych zasobach językowych dla polonistów (Pałka, Kwaśnicka-Janowicz 2017), w którym brak najmniejszej nawet wzmianki o NFJP. Raczej nie sposób rozstrzygnąć, czy w opisanym zdarzeniu chodziło o ignorancję bibliograficzną autorek (i recenzentów wydawniczych oczywiście), czy też o działanie zamierzone: dezinformację, manipulację przez przemilczenie. Czy warto zresztą rozstrzygać? Można w danym kontekście wspomnieć także o zjawisku językoznawczej amnezji, które podniósł Jerzy Bańczerowski (Bańczerowski 2020: 33). 
Poniższy zestaw prezentuje i hasła obecne, i hasła nieobecne w fotokorpusie, $z$ odesłaniami do innych haseł obecnych w NFJP. Został przygotowany, by zademonstrować skalę zjawisk i ich niesłychaną różnorodność - pod względem formalnym, morfologicznym, składniowym, semantycznym, pragmatycznym, a także etymologicznym.

Jest to oczywiście jedynie wybór - seria zarówno jednostek bez spacji wewnętrznej, jak i jednostek ze spacją wewnętrzną ${ }^{8}$. Zwracamy uwagę użytkownikom NFJP na jego jednostki z następujących szczegółowych powodów: a) by wskazać inny fotocytat, $\mathrm{z}$ innego tekstu, z innego roku (życie wyrazów!); b) wskazać inny jeszcze cytat jako cytat pod względem semantycznym i składniowym wyrazistszy ${ }^{9}$; c) wskazać cytat poświadczający istnienie wahań w pisowni, jej nieustabilizowania.

Adria $\rightarrow$ lóżka

Agrygent $\rightarrow$ falaryzm

$\mathrm{AK} \rightarrow$ roboto-godzina

akcik donacyjny $\rightarrow$ akcik

akt donacyjny $\rightarrow$ akt

akt graniczny $\rightarrow$ akcik

akt ziemski $\rightarrow$ akcik

aktor prowincjonalny $\rightarrow$ pensjonacik

aktyw partyjny $\rightarrow$ aktyw

Aleje Jerozolimskie $\rightarrow$ wrotkarski

Alfredowa $\rightarrow$ atencyjka

alkohol etylowy $\rightarrow$ neoheksan

Alkoran $\rightarrow$ szrot

Amerykańskie Towarzystwo Językowe babelizm

amplituda drgań $\rightarrow$ wyważarka

analiza paninterlingwologiczna $\rightarrow$ babelizm

Ancona $\rightarrow$ przeciwwzgórze

Andaluzja $\rightarrow$ cuadrillero

Anglja $\rightarrow$ zarobić; zastolny

aparat fotograficzny $\rightarrow$ chrzęstnąć

aparat kardiotokograficzny $\rightarrow$ kardiotokogram

aparat małoobrazkowy $\rightarrow$ jednowziernikowy

aparat mikrofilmowy $\rightarrow$ jednowziernikowy

aparat państwowy $\rightarrow$ politolog

aparat partyjny $\rightarrow$ politolog

aparat podsłuchowy $\rightarrow$ mikroznak

Archipelag Malajski $\rightarrow$ kariota

8 W tym przeciwstawieniu nie są oczywiście brane pod uwagę wyrażenia z się, któremu towarzyszy obligatoryjnie spacja w prepozycji (por. bać się).

9 Albo, by tak rzec, zgrabniejszy. Preferencja wyrazistości stosowana była przez twórców słownika Doroszewskiego. 
arcydzięgiel litwor $\rightarrow$ fenkuł

arena międzynarodowa $\rightarrow$ antynaród

Argentyńczyk $\rightarrow$ szpila

Armia Krajowa $\rightarrow$ współzwycięski

artyficjalista interlingwistyczny babelizm

asercja kontrafaktowa $\rightarrow$ niefaktowy

Askenazy $\rightarrow$ przeciwturecki

atmosfera ziemska $\rightarrow$ pływotwórczy

atom centralny $\rightarrow$ ligandowy

atom ligandowy $\rightarrow$ ligandowy

automat muzyczny $\rightarrow$ FONIKA

automatyczne przetwarzanie danych jednowziernikowy

ba, ... cukierkowato

Babilonia $\rightarrow$ półcykl

badacz naukowy $\rightarrow$ niekopanie

Ballady i romanse $\rightarrow$ ludycznie

bałucki $\rightarrow$ pobytowiec

bariera językowa $\rightarrow$ babelizm

bariera leksykalna $\rightarrow$ babelizm

bariera leksykalna interdyscyplinarna babelizm

bariera leksykalna międzyjęzykowa babelizm

bariera leksykalna wewnątrzjęzykowa babelizm

bariera logiczna $\rightarrow$ babelizm

bariera pozaleksykalna $\rightarrow$ babelizm

bariera pronuncjacyjna $\rightarrow$ babelizm

bariera psychologiczna $\rightarrow$ babelizm

bariera semantyczna $\rightarrow$ babelizm

barwy kraju $\rightarrow$ florecistka

Beatrycze $\rightarrow$ cudność

bełkot informacyjny $\rightarrow$ babelizm

Beskid Śląski $\rightarrow$ jednozdaniowy

Bessera $\rightarrow$ kacykowy

bestia apokaliptyczna $\rightarrow$ antynapoleonizm

bezpieczeństwo zbiorowe $\rightarrow$ hecarstwo

bęben próżniowy $\rightarrow$ próżniówka

Biblioteka Boya $\rightarrow$ kilkusettomowy

biedrzeniec anyż $\rightarrow$ fenkuł

bieg terenowy $\rightarrow$ alertowy

Biełorusskaja Narodnaja Samopomoszcz probolszewicko

coś bije w oczy $\rightarrow$ geometryczność

coś bije komuś z twarzy $\rightarrow$ wieścić

bitum naturalny $\rightarrow$ chemopak 
bitum pirogeniczny $\rightarrow$ chemopak

Biuro Studiów Osadniczo-Przesiedleńczych $\rightarrow$ PUR

biuro wywiadowcze $\rightarrow$ wywiadowczy

bladoliliowy $\rightarrow$ cukrowo

błona komórkowa $\rightarrow$ protoplast

błona pierwotna $\rightarrow$ protoplast

błona wtórna $\rightarrow$ protoplast

błona zarodkowa $\rightarrow$ seroza

błona żołądkowa $\rightarrow$ wywarzać

Bobrowski $\rightarrow$ CUP

Breżniew $\rightarrow$ półboski

broderie anglaise $\rightarrow$ ciemnolila

broń masowej zagłady $\rightarrow$ antybroń

broń palna $\rightarrow$ wyrzutnik

budownictwo wodne $\rightarrow$ niechemik

być w wielkiej cenie $\rightarrow$ kanarzyca

cal kwadratowy $\rightarrow$ księgowstręt

campingowy $\rightarrow$ combi

Carskie Sioło $\rightarrow$ prarosyjski

Cassino $\rightarrow$ przeciwwzgórze

Castellone $\rightarrow$ przeciwwzgórze

cecha nieodłączna $\rightarrow$ współrozmówca

cegła kominowa $\rightarrow$ kominówka

Centrala Nasiennictwa Ogrodniczego i Szkółkarstwa $\rightarrow$ krezotol

Centralne Stowarzyszenie Pasigrafii $\rightarrow$ babelizm

Centralny Komitet Wykonawczy $\rightarrow$ antypepesowski

cerkiew prawosławna $\rightarrow$ istnieć

Chabówka $\rightarrow$ siernik

chcieć na stronę $\rightarrow$ wyrażonko

Chiny $\rightarrow$ półcykl

$c o s_{1}$ chodzi pod rączkę z $c z y m s_{2} \rightarrow$ niemrok

Chopin $\rightarrow$ wirtuozyjny

chorał gregoriański $\rightarrow$ polifonicznie

choroba umysłowa $\rightarrow$ psychopatia

Chrystus $\rightarrow$ przeczysty

ciało krystaliczne $\rightarrow$ aryl; metaldehyd

ciało zmysłowe $\rightarrow$ zwleczenie

ciche szczęście $\rightarrow$ wyzbyć się

ciskać jakimś wzrokiem $\rightarrow$ kirys

ciśnienie statyczne $\rightarrow$ podsysanie

cogito $\rightarrow$ monadycznie

cokół lądowy $\rightarrow$ batialny 
Conrad $\rightarrow$ conradologia

Continental $\rightarrow$ sztokhomski

corral $\rightarrow$ okólnik-corral

..., co się mówi? $\rightarrow$ poślinić

$k$ toś co się zowie $\rightarrow$ mariażowy

cóż to ma do rzeczy $\rightarrow$ fizykus

cwancygier $\rightarrow$ krajcarowy

cykl rozwojowy $\rightarrow$ śluźnia

czarna jagoda $\rightarrow$ szczawik

czasem ..., a czasem ... $\rightarrow$ pracuś

czasopismo abstraktowe $\rightarrow$ babelizm

Czechow $\rightarrow$ wodewilowość

czek bankowy $\rightarrow$ jednowziernikowy

Częstochowa $\rightarrow$ zaskomlić

człon określający $\rightarrow$ kohiponim

człon określany $\rightarrow$ kohiponim

człon prymarny $\rightarrow$ poprzedzać

człon sekundarny $\rightarrow$ poprzedzać

człowiek myślący $\rightarrow$ neostoik

czynu stal $\rightarrow$ deforma

czysty nonsens $\rightarrow$ kiczowato

dach czterospadowy $\rightarrow$ teak

Daleki Wschód $\rightarrow$ aukuba

Dariusz $\rightarrow$ szmatruz

Dar Pomorza $\rightarrow$ radiooficer

degradacja języka $\rightarrow$ babelizm

demokracja ludowa $\rightarrow$ titowski

dentystyka zachowawcza $\rightarrow$ profetyka

Derecki $\rightarrow$ sino-stalowy

deska okapowa $\rightarrow$ baldach

deska przyokapowa $\rightarrow$ baldach

do rąk własnych czyichś $\rightarrow$ deforma

dochód narodowy $\rightarrow$ doinwestować

dojść do wniosku, że $\ldots \rightarrow$ praantyczny

doktryna Eisenhowera $\rightarrow$ proegipski

Dorn $\rightarrow$ półbut

doskonalić się $\mathbf{w}$ czymś $\rightarrow$ wyzyw

doznać uczucia czegoś $\rightarrow$ ciapka

drabinka przyścienna $\rightarrow$ batut

drabinka sznurowa $\rightarrow$ batut

drapacz nieba $\rightarrow$ dolarowy

droga morska $\rightarrow$ plaża 
druk kursywowy $\rightarrow$ ald

drut formierski $\rightarrow$ profilowy

drzwi wchodowe $\rightarrow$ obcasik

Duch Święty $\rightarrow$ istotowy

Dunajec $\rightarrow$ siernik

dusza pańszczyźniana $\rightarrow$ antypańskość

Dworanowski $\rightarrow$ puński

dyktator mody $\rightarrow$ widzimiś

dyskretna choroba $\rightarrow$ metasyf

dystrybucja komplementarna $\rightarrow$ kinem

dystrybucyjnofonetyczny $\rightarrow$ artykulacyjnofonetyczny

dysza wylotowa $\rightarrow$ dolnopłat

dziad swoje, baba swoje $\rightarrow$ wideoman

działacz społeczny $\rightarrow$ fonografia

Dziennik Popularny $\rightarrow$ anypepesowski; popularniak

dzień świetlny $\rightarrow$ poliestryczny

dziewanna wielkokwiatowa $\rightarrow$ fenkuł

dziurawiec zwyczajny $\rightarrow$ fenkuł

dziwnym zbiegiem okoliczności $\rightarrow$ kacet

efekt termosprężysty $\rightarrow$ polikryształ

Egipt $\rightarrow$ półcykl

elektronowa lampa błyskowa $\rightarrow$ termoczuły

Eli $\rightarrow$ przeczesywać

Elia $\rightarrow$ winotłok

Elsner $\rightarrow$ wirtuozyjny

emulsja fotograficzna $\rightarrow$ termoczuły

emulsja Goldberga $\rightarrow$ termoczuty

emulsja Lippmanna $\rightarrow$ termoczuły

energia atomowa $\rightarrow$ władać

energia kinetyczna $\rightarrow$ rotator

entente cordiale $\rightarrow$ dokumencik

Europa $\rightarrow$ półcykl

Europejczyk $\rightarrow$ półdemon

Ewa $\rightarrow$ kiczowato; lóżka

fakt językowy $\rightarrow$ morfologiczność

fala dźwiękowa $\rightarrow$ percepcja

fala ultrakrótka $\rightarrow$ krótkofalarski

fale eteru $\rightarrow$ kinoterapia

falsyfikator szkiełkowy $\rightarrow$ prozaizacja

Federacja Syryjska $\rightarrow$ newralgiczność

Felek $\rightarrow$ szpila

fellow-travellers $\rightarrow$ pro-komunista 
Figlacki $\rightarrow$ odrwić

figura geometryczna $\rightarrow$ kongruencja

figura płaska $\rightarrow$ integrometr

Filmowa Agencja Wydawnicza $\rightarrow$ nieluksusowy

filtracja etniczna $\rightarrow$ filtracja

folia samoprzylepna $\rightarrow$ szafko-półka

forma prefiksalna $\rightarrow$ przebaba

formacja bezprzedrostkowa $\rightarrow$ zadych

fortuna non mutat genus $\rightarrow$ iberski

fraza rzeczownikowa $\rightarrow$ nierekursywny

Fryderyk II $\rightarrow$ pruski

gabinet stomatologiczny $\rightarrow$ tiranal

Galicz $\rightarrow$ pierestrojka

gałka oczna $\rightarrow$ paluchowy; porażenny

Generalna Gubernia $\rightarrow$ cywilny

Garigliano $\rightarrow$ przeciwwzgórze

gatunek literacki $\rightarrow$ ulirycznianie

Gdańsk $\rightarrow$ trikowo

Genewa $\rightarrow$ ataszat

genjusz bez teki $\rightarrow$ prototypowy

geografia językowa $\rightarrow$ mikrotyp

geografia lingwistyczna $\rightarrow$ mikrotyp

glina formierska $\rightarrow$ profilowy

głowa cukru $\rightarrow$ nadgrób

głucha mogiła $\rightarrow$ nowowyrosły

głupi idiota $\rightarrow$ rozbazgrać

gmach publiczny $\rightarrow$ gimnazjon

Gminna Spółdzielnia Samopomocy Chłopskiej $\rightarrow$ krezotol

Godfryd $\rightarrow$ daleczny

godło państwowe $\rightarrow$ honoracja

godność osobista $\rightarrow$ niepodarek

godny napiętnowania $\rightarrow$ antynazizm

Górna Wieś $\rightarrow$ siernik

gra słowna $\rightarrow$ polityczno-aluzyjny

Grossman $\rightarrow$ przeciwśrodek

grupa doświadczalna $\rightarrow$ granulocyt

grupa ekumeniczna $\rightarrow$ roboczo

grupa kontrolna $\rightarrow$ granulocyt

grupa nominalna $\rightarrow$ akusatiw

grupa operacyjna $\rightarrow$ cywilny; kobierski

grupa wyrazowa $\rightarrow$ poprzedzać

gryzak kształtny $\rightarrow$ profilowy 
Grzegorz $\rightarrow$ meteoryta

gustować w kimś $\rightarrow$ ZLEP

gwara piśmienna $\rightarrow$ różnoterytorialny

gwara regionalna $\rightarrow$ różnoterytorialny

gwiazda pierwszej wielkości $\rightarrow$ AZS

hala targowa $\rightarrow$ gimnazjon

hala wejściowa $\rightarrow$ dolarowy

handel komisowy $\rightarrow$ składownik

Hanna $\rightarrow$ korowaj

Hanuszkiewicz $\rightarrow$ wodewilowość

Harasymowicz $\rightarrow$ głuchodaleki

hełm wiatrowy $\rightarrow$ owsik

hierarchia kościelna $\rightarrow$ neointegryzm

hierarchja społeczna $\rightarrow$ bakcyl

huta cynkowa $\rightarrow$ cynkownik

hygrometr włosowy $\rightarrow$ wilgociomierz

II Rzeczpospolita $\rightarrow$ wszechpodaż

Ilijicz $\rightarrow$ półboski

Indianin $\rightarrow$ kacykowy

Indie $\rightarrow$ półdemon

Indus $\rightarrow$ półdemon

indyferentyzm fabryczny $\rightarrow$ fabryczność

instrument muzyczny $\rightarrow$ FONIKA

instytucja naukowa $\rightarrow$ tokijski

insza inszość $\rightarrow$ inszość

integrator mechaniczny $\rightarrow$ integrometr

interes osobisty $\rightarrow$ sierotka

interwał $\rightarrow$ jednogłosowy

Irka $\rightarrow$ szotowy

iść do nieba $\rightarrow$ księżunio

iść w sałdaty $\rightarrow$ wójtowy

iść z kimś na udry $\rightarrow$ dudlić

Iwan $\rightarrow$ półbut; wlepić

Iwanowicz $\rightarrow$ półbut

ttos $_{1}$ i $k$ tos $_{2}$ w jednej osobie $\rightarrow$ fizykus

izba stołowa $\rightarrow$ sklenica

coś jak malowanie $\rightarrow$ źreniczka

.. jak nieboskie stworzenie ... $\rightarrow$ mikst

$\ldots$ jak wryty $\rightarrow$ plutonik

$\ldots$, jak nazywasz, ... $\rightarrow$ geszefciarski

Janek $\rightarrow$ kiczowato

Jassem $\rightarrow$ artykulacyjnofonetyczny 
Jassemowski $\rightarrow$ artykulacyjnofonetyczny

jednostka czasu $\rightarrow$ rozwijarka

jednostka wsparcia bojowego $\rightarrow$ niezawijanie

jemioła pospolita $\rightarrow$ fenkut

jest $\mathbf{w}$ kimśs $_{1} \mathbf{w}$ stosunku do kogośs $_{2}$ coś jakiegoś $\rightarrow$ nieprzełamanie

komuś $_{1}$ jest kogoś $_{2}$ żal $\rightarrow$ ściąga

język literacki $\rightarrow$ dwuznak

język mówiony $\rightarrow$ różnoterytorialny

język ojczysty $\rightarrow$ duchowokreatywny

język pisany $\rightarrow$ różnoterytorialny

język pomorski $\rightarrow$ wszechwęgierskość

Jim $\rightarrow$ colt

Jörgen $\rightarrow$ szlaczek

Józef $\rightarrow$ pieniężnie

K'ang Yu-wei $\rightarrow$ sinocentryzm

Kaczorowski $\rightarrow$ CUP

kadra kierownicza $\rightarrow$ deglomeracyjny

kalać gniazdo $\rightarrow$ renegatka

kamera fotograficzna $\rightarrow$ jednowziernikowy

kamera telewizyjna $\rightarrow$ termopara

kamica moczowa $\rightarrow$ hematuria

kamień księżycowy $\rightarrow$ łupek

kapusta pastewna $\rightarrow$ facelia

kara pieniężna $\rightarrow$ plebejusz

kara śmierci $\rightarrow$ niezdjęcie

kariota parząca $\rightarrow$ kariota

Karol $\rightarrow$ pieniężnie

karta katalogowa $\rightarrow$ jednowziernikowy

karta wizytowa $\rightarrow$ zoczyć

kasa pancerna $\rightarrow$ mikroznak

katalog centralny $\rightarrow$ jednowziernikowy

Katolik Codzienny $\rightarrow$ nielegalnie

kierować pod czyimś adresem $c o s s$ dekoratorka

Kiersnowski $\rightarrow$ zląc się

kit kazeinowy $\rightarrow$ sernikowy

kit sernikowy $\rightarrow$ sernikowy

klasa zamknięta $\rightarrow$ dwulufy

klej chlorokauczukowy $\rightarrow$ neoprenowy

klej kazeinowy $\rightarrow$ sernikowy

klej sernikowy $\rightarrow$ sernikowy

Knurów $\rightarrow$ siernik

Kochanowski $\rightarrow$ stimmung 
kocioł Kornwala $\rightarrow$ płomienica

kogoś spotkał jakiś despekt $\rightarrow$ wyraczyé

kogitacja $\rightarrow$ monadycznie

kolumna głośnikowa $\rightarrow$ FONIKA

kołowrotek ręczny $\rightarrow$ rozwijarka

Komentarze do fotografii $\rightarrow$ antypoezja

komórka jajowa $\rightarrow$ oogamia

komórka nerwowa $\rightarrow$ neurocyt

komórka roślinna $\rightarrow$ protoplast

kompania finansowa $\rightarrow$ decymator

komplet pościelowy $\rightarrow$ dekatyza

konfiguracja inchoatywna $\rightarrow$ grammem

konfiguracja iteratywna $\rightarrow$ grammem

konfiguracja potencjalna $\rightarrow$ grammem

konik polny $\rightarrow$ tyrs

Konnor $\rightarrow$ arkon

konsekwencje karne $\rightarrow$ prywatysta

konstanta rytmiczna $\rightarrow$ prozodyjny

Konstanty $\rightarrow$ pieniężnie

Konterski $\rightarrow$ szpila

konwalia majowa $\rightarrow$ fenkut

konwencja genewska $\rightarrow$ nielegalnie

kończyna dolna $\rightarrow$ śródstopie

koper włoski $\rightarrow$ fenkuł

Kopernik $\rightarrow$ cny

kostka cukru $\rightarrow$ lastrykarz

Kostrowicz $\rightarrow$ zaszarpać

kosz plecowy $\rightarrow$ udźwig

kościół ewangelicki $\rightarrow$ zwinglianizm

Kościół katolicki $\rightarrow$ cerkiew; ROPCiO

kościół parafialny $\rightarrow$ honoracja

kościół reformowany $\rightarrow$ zwinglianizm

kółko zębate $\rightarrow$ wręb

kra lodowcowa $\rightarrow$ porwak

Kraina Śniegu $\rightarrow$ neosensualizm

Kraków $\rightarrow$ pieniężnie; signor

krew obwodowa $\rightarrow$ granulocyt

Kristus $\rightarrow$ szrot

krok za krokiem $\rightarrow$ szyfracja

krosno mechaniczne $\rightarrow$ rozwijarka

krosno tasiemkarskie $\rightarrow$ rozwijarka

krosno tkackie nożne $\rightarrow$ podstopie 
Krościenko $\rightarrow$ siernik

król kierowy $\rightarrow$ wytwórczy

krótko mówiąc $\rightarrow$ giełdowicz; posoborowo

Krystyna $\rightarrow$ przeciwważyć

kryzys wewnętrzny $\rightarrow$ neostoik

krzemian glinowy $\rightarrow$ cyjanit

Kserkses $\rightarrow$ szmatruz

Księga Genesis $\rightarrow$ jednoźródłowy

kult hiperduleutyczny $\rightarrow$ wszechwysławianie

kultura salonowa $\rightarrow$ antymuzealny

Kuria rzymska $\rightarrow$ posoborowy

kwas cyjanowy $\rightarrow$ aryl

kwas fluorokrzemowy $\rightarrow$ fluoroform

kwas fosforawy $\rightarrow$ dwufosforowy

kwas octowy $\rightarrow$ asocjat

kwas ortofosforowy $\rightarrow$ hemopirol

kwas siarkowy $\rightarrow$ romboidalny

kwas solny $\rightarrow$ romboidalny

kwas śluzowy $\rightarrow$ śluz

kwiaciarstwo szklarniowe $\rightarrow$ hydroponik

kwiat lipowy $\rightarrow$ motopiryna

kwiat muchówkowy $\rightarrow$ polichlorować

kwiat pyłkowy $\rightarrow$ polichlorować

kwieciak jabłkowiec $\rightarrow$ owocowiec

lampa błyskowa $\rightarrow$ flesz

lampa rentgenowska $\rightarrow$ tomograf

las tropikalny $\rightarrow$ widłoząb

leczenie abortywne $\rightarrow$ poronny

leczenie operacyjne $\rightarrow$ syndaktylia

leczenie szpitalne $\rightarrow$ kardiotokogram

legitymacja partyjna $\rightarrow$ antynatoliński

Leon $\rightarrow$ pierśnica

Leonid $\rightarrow$ półboski

liczyć się ze słowami $\rightarrow$ flircik

ligand dwukleszczowy $\rightarrow$ ligandowy

Limanowa $\rightarrow$ siernik

Linde $\rightarrow$ zasep

linia bramkowa $\rightarrow$ wolej

linia kolejowa $\rightarrow$ kilkutorowy

linia rozwojowa czegos $\rightarrow$ metanauka

linja kolejowa $\rightarrow$ roszada

list protestacyjny $\rightarrow$ dwunumerowy 
list zalotny $\rightarrow$ przedsalon

Literackie Towarzystwo Przyjaciół Polski $\rightarrow$ grekofil

literatura społeczna $\rightarrow$ poputczik

Litwa $\rightarrow$ przeciwwzgórze

logika formalna $\rightarrow$ metasemiologia

lokalny patriotyzm $\rightarrow$ szczeciniak

los człowieczy $\rightarrow$ wirtuozersko

ludowa sprawiedliwość $\rightarrow$ ludycznie

Ludwik $\rightarrow$ kiczowato

lumpenproletariat $\rightarrow$ pobytowiec

lustrzanka jednowziernikowa $\rightarrow$ jednowziernikowy

lutnia samoczynna $\rightarrow$ wywiewka

Lwów $\rightarrow$ cycasty

ładunek funkcjonalny $\rightarrow$ niekodowy

Łatkowski $\rightarrow$ szmatruz

lawa sądowa $\rightarrow$ czasówka

łączność bezprzewodowa $\rightarrow$ mikroznak

łoże małżeńskie $\rightarrow$ kątek

Łódź $\rightarrow$ meteoryta; zastolny

łódź dwuwiosłowa $\rightarrow$ dwururny

łódź żeglarska $\rightarrow$ bacik

łuk piszczelowy $\rightarrow$ paluchowy

Łukasz $\rightarrow$ lóżka

łupek pisarski $\rightarrow$ tupek

łupek zieleńcowy $\rightarrow$ porfiroid

machać ręką na znak, że $\ldots \rightarrow$ centym

madrygał gotycki $\rightarrow$ polimetria

$\operatorname{coś}_{1}$ ma imię czegoś $_{2} \rightarrow$ gilotynka

makroruch Browna $\rightarrow$ mikroruch

malowidło naskalne $\rightarrow$ neofit

Majer $\rightarrow$ pieniężnie

Majeranowski $\rightarrow$ pieniężnie

Majerova $\rightarrow$ pieniężnie

Malczewski $\rightarrow$ conradolog; ulirycznianie

małpia bruzda $\rightarrow$ paluchowy

maniak pracy $\rightarrow$ kinoholik

Marcin $\rightarrow$ półdrwić

Marie $\rightarrow$ pieniężnie

Marja $\rightarrow$ szlaczek

Marjan $\rightarrow$ meteoryta

marskość wątroby $\rightarrow$ antyplazmina

masa skalna $\rightarrow$ porwak 


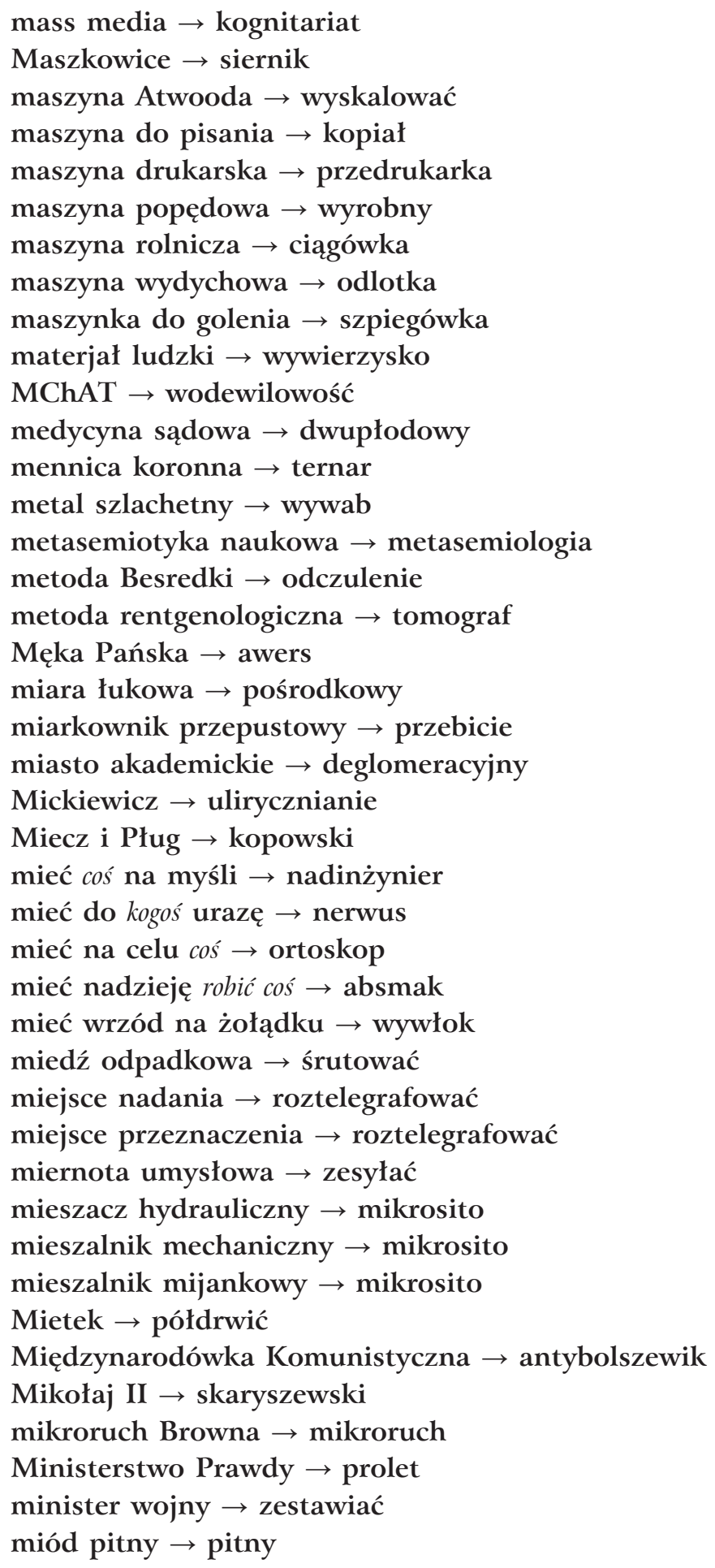


miód przaśny $\rightarrow$ pitny

mleko wapienne $\rightarrow$ mikrosito

Młoda Polska $\rightarrow$ wytwórczy

młotek lasowy $\rightarrow$ próchnica

mniej lub więcej jak $\rightarrow$ nieleksykograf

mniejszość narodowa $\rightarrow$ nielojalny

mniszek pospolity $\rightarrow$ fenkuł

modyfikacja fonetyczna $\rightarrow$ sfosowski

modyfikacja morfologiczna $\rightarrow$ sfosowski

moim zdaniem, ... $\rightarrow$ bąbelek

moment magnetyczny $\rightarrow$ podpoziom

moralność tymczasowa $\rightarrow$ przed-sokratejski

morfem gramatyczny $\rightarrow$ grammem

Moskal $\rightarrow$ sienkiewiczyzm

Moskwa $\rightarrow$ przeciwturecki

motyw kompozycyjny $\rightarrow$ hydrotechnika

mowa okolicznościowa $\rightarrow$ honoracja

ktoś może być spokojny $\rightarrow$ osijecki

można by rzec $\rightarrow$ posoborowo

mównica rzymska $\rightarrow$ rostrum

Muszyński $\rightarrow$ szopkarz

muza powietrzna $\rightarrow$ kinoterapia

myśliwiec odrzutowy $\rightarrow$ dolnopłat

Myślenice $\rightarrow$ siernik

na każdym kroku $\rightarrow$ nieegzotyczny

na miłość Boską $\rightarrow$ motopiryna

na równych prawach $\rightarrow$ tercjowo

nabój elektryczny $\rightarrow$ neutrino

Naczelnik Państwa $\rightarrow$ kurierski

nadział chłopski $\rightarrow$ ufijski

nakaz trzech pieczęci $\rightarrow$ antymanichejski

coś należy do rzadkości $\rightarrow$ dekoratorka

zrobić coś na noc $\rightarrow$ motopiryna

napęd parowy $\rightarrow$ niezawijanie

napęd ręczny $\rightarrow$ rozwijarka

napięcie mięśniowe $\rightarrow$ paluchowy

narkoza wziewna $\rightarrow$ wziewny

Narodowa Partia Afrykanerów $\rightarrow$ baasskap

naród afrykanerski $\rightarrow$ krugerrand

nasienie męskie $\rightarrow$ ejakulat

jakiś na wygląd $\rightarrow$ lejb-medyk

nazwa plemienna $\rightarrow$ wyraz-rdzeń 
nazwa zaprzeczona $\rightarrow$ nieenergia

Neapol $\rightarrow$ przeciwwzgórze

nędza moralna $\rightarrow$ zesyłać

ktoś nie po kolei ma $\rightarrow$ pornus

ni to $\cos _{1}$, ni to $\cos _{2} \rightarrow$ fantomiczny

niciarka wózkowa $\rightarrow$ widełkowy

$\ldots$, niechby sobie, ... $\rightarrow$ wyraczyć

$\cos _{1}$ nie grzeszy czymśs $_{2} \rightarrow$ kokardka

coś nie przynosi komuś ujmy $\rightarrow$ komórkowiec

coś nie ulega kwestji $\rightarrow$ dokooptowanie

nie wiedzieć skąd $\rightarrow$ przedrżeć

nie zamiast $c z e g o s_{1}$, ale łącznie $\mathrm{z} c z y m s_{2} \rightarrow$ gipsownia

niedorozwój umysłowy $\rightarrow$ paluchowy

Niemcy $\rightarrow$ zarobić

nietykalność cielesna $\rightarrow$ kodeksowo

komuś nie zbywa na czymś $\rightarrow$ wspólniczka

$\operatorname{coś}_{1}$ nosi nazwę czegoś $\rightarrow$ piaszczysko

nostrzyk żółty $\rightarrow$ fenkuł

nowotwór łagodny $\rightarrow$ chrzęstniak

Nowy Dzień Robotnika $\rightarrow$ nieeksportowy

nóż zbożowy $\rightarrow$ farinotom

nucić coś pod nosem $\rightarrow$ czterogwiazdkowy

objąć dowództwo czegoś $\rightarrow$ skiepścieć

Oblicze Dnia $\rightarrow$ popularniak

obraz kliniczny $\rightarrow$ pandemia

obróbka hydrotermiczna $\rightarrow$ kilkuporcjowy

obrządek rzymskokatolicki $\rightarrow$ utaić

ktoś o jakiejś budowie $\rightarrow$ florecistka

obywatel ziemski $\rightarrow$ giełdowicz

Ocean Lodowaty $\rightarrow$ termofit

Ochotny riad $\rightarrow$ riad

odcinek czasowy $\rightarrow$ idealizująco

odczyn Bordet-Wassermanna $\rightarrow$ bakterioliza

odkrywacz cząstek elementarnych $\rightarrow$ odkrywacz

od małego $\rightarrow$ wypleć

odnieść sukces $\rightarrow$ colt

coś odpowiada czyimś wymaganiom $\rightarrow$ albumik

odrodzony PPS $\rightarrow$ nieeksportowy

od ucha do ucha $\rightarrow$ beatnik; wpółgłośny

oficer rezerwy $\rightarrow$ krawatowy

o ile wiem $\rightarrow$ posadzina

ojciec duchowy czyjs $\rightarrow$ wyraziciel 
okres czasu $\rightarrow$ subskrypt

okres międzywojenny $\rightarrow$ hydroponik; kanat

olej dieslowy $\rightarrow$ morfolina

olej lniany $\rightarrow$ morfolina

olej napędowy $\rightarrow$ morfolina

olej rycynowy $\rightarrow$ morfolina

olej silikonowy $\rightarrow$ niemydlany

Ołsufiew $\rightarrow$ sztokholmski

opinia publiczna $\rightarrow$ grekofil; neoetatysta; rozbieg

opony mózgowe $\rightarrow$ pandemia; witaminowy

organ płciowy $\rightarrow$ pracecha

organ rozrodczy $\rightarrow$ skatologia

Orzeszkowa $\rightarrow$ arkon

osiągnąć jakiś cel $\rightarrow$ prząd

Ossuna $\rightarrow$ cuadrillero

ostatnia kwadra księżyca $\rightarrow$ wietek

Ostatnia Wieczerza $\rightarrow$ śliżyk

ośrodek narciarski $\rightarrow$ AZS

oświata ludowa $\rightarrow$ polifurkacja

oświetlenie elektryczne $\rightarrow$ patronit

pagórek muszlowy $\rightarrow$ kadirijja

Otton $\rightarrow$ winotłok

owoc jadalny $\rightarrow$ ulężenie

palec boczny $\rightarrow$ śródstopie

palec wielki $\rightarrow$ śródstopie

pałacyk myśliwski $\rightarrow$ skaryszewski

..., pamiętam jak dziś, ... $\rightarrow$ winogronko

pan domu $\rightarrow$ dekoratorka

pani domu $\rightarrow$ dekoratorka

panie ładny $\rightarrow$ arcybałagan

panna służąca $\rightarrow$ dekoratorka

państwowy nadzór budowlany $\rightarrow$ kadrowo

papier bezdrzewny $\rightarrow$ patronit

papier drzewny $\rightarrow$ patronit

papier ilustracyjny $\rightarrow$ patronit

papier kredowany $\rightarrow$ patronit

papier offsetowy $\rightarrow$ patronit

papier pigmentowy $\rightarrow$ patronit

papier piśmienny $\rightarrow$ patronit

para małżeńska $\rightarrow$ motelik

para odlotowa $\rightarrow$ patronit

parapet okienny $\rightarrow$ ościeże 
para wodna $\rightarrow$ paropowietrzny; patronit para wydychowa $\rightarrow$ odlotka paradoks d'Alemberta $\rightarrow$ patronit paradoks Dubuata $\rightarrow$ patronit paradoks hydrostatyczny $\rightarrow$ patronit paradygmat fleksyjny $\rightarrow$ pluralny Paryż $\rightarrow$ ataszat pas pędny $\rightarrow$ patronit pas podsadzkowy $\rightarrow$ patronit pas transmisyjny $\rightarrow$ krupon pasmo nośne $\rightarrow$ patronit pasywizm filozoficzny $\rightarrow$ metapoziom pasza roślinna $\rightarrow$ skarmiać patriotyzm państwowy $\rightarrow$ partokracja Pelagia $\rightarrow$ cycaty

Pescopennataro $\rightarrow$ przeciwwzgórze pewnik filozoficzny $\rightarrow$ monadycznie pęcherz moczowy $\rightarrow$ hematuria pęcherz pławny $\rightarrow$ ichtiokol pętlica łokciowa $\rightarrow$ paluchowy Piechal $\rightarrow$ meteoryta pień nerwowy $\rightarrow$ nerwoból pierścień smarujący $\rightarrow$ maziarz pierwsza pomoc $\rightarrow$ babkarstwo pies morski $\rightarrow$ prozator pies myśliwski $\rightarrow$ oszczek pieszczotka $\rightarrow$ córeńka Pietrowicz $\rightarrow$ wlepić pisarz prowentowy $\rightarrow$ dekoratorka pismo jusowe $\rightarrow$ jusowy pismo linearne $\mathrm{A} \rightarrow$ azjanicki pismo linearne $\mathrm{B} \rightarrow$ azjanicki Pius IX $\rightarrow$ dziejopisarz Piwońska $\rightarrow$ kafelek placek kartoflany $\rightarrow$ śliżyk plejzer $\rightarrow$ bandażyk plewka dolna $\rightarrow$ plewka plewka górna $\rightarrow$ plewka płaz bezogonowy $\rightarrow$ ropuszka płeć odmienna $\rightarrow$ koicja płyn do pisma utajonego $\rightarrow$ mikroznak płyn nasienny $\rightarrow$ ejakulat 
płyta pilśniowa $\rightarrow$ rębak

płyta wiórowa $\rightarrow$ rębak

po prawdzie rzekłszy $\rightarrow$ dusiołek

po rybałtowsku $\rightarrow$ niepodarek

pobożne życzenie $\rightarrow$ dekoratorka

pocisk rakietowy $\rightarrow$ laserowo

poczucie winy $\rightarrow$ kamikaze

pod tym względem $\rightarrow$ pedofil

pod względem czegoś $\rightarrow$ wyzłota

podać coś $\mathbf{w}$ wątpliwość $\rightarrow$ przedsiębierca

podawać sobie wiadomość, że $\ldots \rightarrow$ nabywczyni

podbiał pospolity $\rightarrow$ fenkuł

podjąć okupację czegoś $\rightarrow$ jedyneczka

podmiot myślący $\rightarrow$ idealizm

podstawa derywacyjna $\rightarrow$ krężołek

podsunąć komuś myśl, iż ... $\rightarrow$ niewejście

pokój bawialny $\rightarrow$ kątek

Polak $\rightarrow$ atencyjka

pole psychologiczne $\rightarrow$ antyfonia

pole uprawne $\rightarrow$ ścierń

Poleszuk $\rightarrow$ szłyk

$k t o s_{1}$ policzony między ${\operatorname{kog} o s_{2}}_{2} \rightarrow$ afrykanolog

politlenek fenylenu $\rightarrow$ fenylen

Polska $\rightarrow$ trikowo

Polska Agencja Prasowa $\rightarrow$ jedyneczka

Polska Ludowa $\rightarrow$ niepodarek

Polski Przegląd Radiologiczny $\rightarrow$ tomograf

Polskie Siły Zbrojne $\rightarrow$ współzwycięski

polszczyzna literacka $\rightarrow$ różnoterytorialny

pomieszczenie gospodarcze $\rightarrow$ poreperować

pomoc domowa $\rightarrow$ niekonsument

Pomocki $\rightarrow$ odrwić

pompa napowietrzająca $\rightarrow$ owsik

pompa rotodynamiczna $\rightarrow$ rotodynamiczny

popaść w rozpacz $\rightarrow$ wójtowy

popęd płciowy $\rightarrow$ ipsacja

popęd seksualny $\rightarrow$ krępująco; pracecha

poprawność polityczna $\rightarrow$ KRRiT

porządek dzienny $\rightarrow$ dumski

porządek naturalny $\rightarrow$ metahistoryczny

porządek prawny $\rightarrow$ kodeksowo

posłowa nadzwyczajna $\rightarrow$ posłowa 
postęp techniczny $\rightarrow$ doinwestować

postęp technologiczny $\rightarrow$ doinwestować

powaga lekarska $\rightarrow$ asesorowa

Potocka $\rightarrow$ atencyjka

powierzać coś $\mathbf{w}$ czyjeś ręce $\rightarrow$ niewaleczny

powieść marynarska $\rightarrow$ prozator

powieść obyczajowa $\rightarrow$ cyganolog

powieść rodzinna $\rightarrow$ jednoźródłowy

powietrze robocze $\rightarrow$ wyrobny

powłoka elektronowa $\rightarrow$ ligandowy

powstanie kościuszkowskie $\rightarrow$ exul

powstanie listopadowe $\rightarrow$ sepecik

poznać się na czymś $\rightarrow$ wyżlak

pozostawać w sprzeczności z czymś $\rightarrow$ koniuczek

pozycja bibliograficzna $\rightarrow$ niekompletność

PPS $\rightarrow$ WKR

praca magisterska $\rightarrow$ prematuralny

pracownia reprograficzna $\rightarrow$ jednowziernikowy

Praga Czeska $\rightarrow$ nielojalny

Prawda polska $\rightarrow$ policki

Prawda ruska $\rightarrow$ policki

prawdę mówiąc, $\ldots \rightarrow$ płachetek

prawo addytywności $\rightarrow$ toluen

prawo międzynarodowe $\rightarrow$ azylować

prawo naturalne $\rightarrow$ pracecha

prawy łącznik $\rightarrow$ wolej

prąd elektryczny $\rightarrow$ niechemik; termopara

prąd wodny $\rightarrow$ piaszczysko

prądnica prądu zmiennego $\rightarrow$ alternator

prima facie $\rightarrow$ inżynieryjnie

prom łańcuchowy $\rightarrow$ farbiarka

promieniowanie gamma $\rightarrow$ mPOk

promyczek $\rightarrow$ córeńka

Protopopow $\rightarrow$ sztokhomski

próba śródskórna $\rightarrow$ granulocyt

przebieg kliniczny $\rightarrow$ porażenny

przedmiot fizyczny $\rightarrow$ terminizm

przedtatarski $\rightarrow$ prarosyjski

przemiana materii $\rightarrow$ lizawy

przemysł cukrowniczy $\rightarrow$ taryfowo

przemysł naftowy $\rightarrow$ taryfowo

przemysł papierniczy $\rightarrow$ rębak 
przenieść się do wieczności $\rightarrow$ ricmus

przepisy meldunkowe $\rightarrow$ deglomeracyjny

przewód jednodrutowy $\rightarrow$ wpieracz

coś przez pół jakieśs, przez pół jakieśs $\rightarrow$ wyznawczy

przędzarka skrzydełkowa $\rightarrow$ rozwijarka

przodująca partia $\rightarrow$ przebaczacz

przybierać jakąś postawę $\rightarrow$ nielegalnie

przychodzić do siebie $\rightarrow$ pałać

$\ldots$, przy czym ... $\rightarrow$ euforyczność; roztelegrafować

przyjąć jakąś postać $\rightarrow$ toluen

przyroda ożywiona $\rightarrow$ antymatematyk

przyszła kolej na coś $\rightarrow$ szypszyna

przywilej królewski $\rightarrow$ rozwijarka

psuć komuś jakiś humor $\rightarrow$ raps

punkt newralgiczny $\rightarrow$ newralgiczność

pustynia libijska $\rightarrow$ widokres

Rabka $\rightarrow$ siernik

rad nierad $\rightarrow$ altanka

Rada Naukowa dla Zagadnień Ziem Odzyskanych $\rightarrow$ PUR

radca stanu $\rightarrow$ dehumor

rasa europejska $\rightarrow$ referentka

realizm kreaturalny $\rightarrow$ kreaturalny

redakcja merytoryczna $\rightarrow$ korektornia

redakcja techniczna $\rightarrow$ korektornia

reforma rolna $\rightarrow$ nieeksportowy; zeszłowieczny

reformy józefińskie $\rightarrow$ niewiążąco

resort bezpieczeństwa $\rightarrow$ przebaczacz

rewolucja październikowa $\rightarrow$ zeszłowieczny

rewolucja sycylijska $\rightarrow$ polityczno-militarny

ręczna dziewiarka osnowowa $\rightarrow$ rozwijarka

robić coś pod sekretem $\rightarrow$ wiwlas

rodzina paprotkowatych $\rightarrow$ porozcinać

rodzina skalnicowatych $\rightarrow$ śledziennica

Rosja europejska $\rightarrow$ posieleniec

roślina uprawna $\rightarrow$ klimatotwórczy

Roxolanki albo Ruskie Panny $\rightarrow$ fest

Rozanow $\rightarrow$ augsburgski

rozciągarka Arkwrighta $\rightarrow$ rozwijarka

rozkład jazdy pociągów $\rightarrow$ hełmik

rozmnażanie płciowe $\rightarrow$ oogamia

rozprawa sądowa $\rightarrow$ gimnazjon

roztwór Fehlinga $\rightarrow$ romboidalny 
roztwór fizjologiczny $\rightarrow$ cytolityczny

rozwolnienie duchowe $\rightarrow$ posoborowo

równouprawnienie kobiet $\rightarrow$ deforma; wyzłota

ruch Browna $\rightarrow$ mikroruch

ruch kołowy $\rightarrow$ deferent

ruch obrotowy $\rightarrow$ wyważarka

ruch sprzężony $\rightarrow$ tomograf

rumianek pospolity $\rightarrow$ fenkut

rurociag wydychowy $\rightarrow$ odlotka

rym gramatyczny $\rightarrow$ zerokońcówkowy

rym półgramatyczny $\rightarrow$ zerokońcówkowy

rynek wewnętrzny $\rightarrow$ nowozdobyty

Rywjera $\rightarrow$ armator

rzecz charakterystyczna $\rightarrow$ hasłowo

rzeczownik atrybutywny $\rightarrow$ wyrwisko

rzecz myśląca $\rightarrow$ monadycznie

rzecz sama w sobie $\rightarrow$ fenomenalizm

rzecz zdumiewająca, że ... $\rightarrow$ prozator

rzepa ścierniskowa $\rightarrow$ facelia

Rzesza Niemiecka $\rightarrow$ niepysznie

Rzgów $\rightarrow$ zastolny

rzucić jakieśs spojrzenie z pod jakichśs brwi $\rightarrow$ prowincjusz

rzucić okiem $\rightarrow$ pracuś

Rzym $\rightarrow$ lóżka; pieniężnie

sadzić komuś krociami diabłów $\rightarrow$ wyraczyć

sala koncertowa $\rightarrow$ dokolutka

sala przyjęć $\rightarrow$ wywoskować

salwa karabinowa $\rightarrow$ płucnochory

samolot wyczynowy $\rightarrow$ dolnopłat

Samson $\rightarrow$ szmatruz

Sangro $\rightarrow$ przeciwwzgórze

sąd duchowny $\rightarrow$ niewzywanie

sąd podkomorski $\rightarrow$ akcik

sąd świecki $\rightarrow$ niewzywanie

scenariusz filmowy $\rightarrow$ szpiegówka

schody kręte $\rightarrow$ idealizująco

Scypion $\rightarrow$ szmatruz

semantem werbalny $\rightarrow$ grammem

sepia brunatna $\rightarrow$ sepia

sędzia prywatny $\rightarrow$ kognicyjny

siedziba ludzka $\rightarrow$ ścierń

siedzieć w kucki $\rightarrow$ szynel 
silnica robocza $\rightarrow$ wyrobny

silnik jednofazowy $\rightarrow$ krótkozwarty

silnik odrzutowy $\rightarrow$ dolnopłat

silnik wodny $\rightarrow$ rowijarka

silnik wydychowy $\rightarrow$ odlotka

siła robocza $\rightarrow$ substytucyjnie

siła sprawcza $\rightarrow$ dwujedność

siła udźwigowa $\rightarrow$ udźwig

siostrzyca ziemi $\rightarrow$ siostrzyca

skala naturalna $\rightarrow$ kalkowy

skała warstwowa $\rightarrow$ kamienisko

skaza krwotoczna $\rightarrow$ kurczliwość

skąpić grosza $\rightarrow$ wpółgłośny

skład chemiczny czegoś $\rightarrow$ polityp

składnik pokarmowy $\rightarrow$ skarmiać

skowronek polny $\rightarrow$ bezlotka

skrót myślowy $\rightarrow$ brunatnobury

słodkie kartofle $\rightarrow$ ginseng

Słowianie lubimy sielanki $\rightarrow$ produkować

słownictwo przyrodnicze $\rightarrow$ nie-filolog

słupek kilometrowy $\rightarrow$ wyzgrzytać

Smrokowski $\rightarrow$ przeciwwzgórze

sobór trydencki $\rightarrow$ italianizacja

Sokole Oko $\rightarrow$ zaszeptać

Sołowjow $\rightarrow$ augsburgski

Sołżenicyn $\rightarrow$ bałtysta

sortownik bębnowy $\rightarrow$ sepia

sortownik sitowy $\rightarrow$ sepia

Sowiński $\rightarrow$ wirtuozyjny

sól kuchenna $\rightarrow$ cytolityczny

specyfik lekarski $\rightarrow$ gerokaina

coś spod ciemnej gwiazdy $\rightarrow$ dupowaty

spódnica damska $\rightarrow$ widzimiś

spółgłoska przednia $\rightarrow$ artykulacyjnofonetyczny

sprawa prywatna $\rightarrow$ woźnieński

sprawa publiczna $\rightarrow$ woźnieński

ktoś sprezentował broń $\rightarrow$ niedźwiedzi

stacja benzynowa $\rightarrow$ motelik

stacya mostowa $\rightarrow$ mostkowy

stan rzeczy $\rightarrow$ dywizjoner; nieetnolog

Stanisław $\rightarrow$ cukierkowato

Stara Wieś $\rightarrow$ siernik 
Stary Targ $\rightarrow$ protoscholarcha

Stawinoga $\rightarrow$ szmatruz

ster kierunkowy $\rightarrow$ dolnopłat

stereoradiografia medyczna $\rightarrow$ obiektywowy

stipendium $\rightarrow$ udarzyć

stolica świata $\rightarrow$ niekontuszowy

stos kremacyjny $\rightarrow$ niehindus

stosunki dyplomatyczne $\rightarrow$ proegipski

stosunki miłosne $\rightarrow$ witriolej

Stowarzyszenie Kupców Polskich $\rightarrow$ honoracja

stół bilardowy $\rightarrow$ łuza

stół mikserski $\rightarrow$ FONIKA

stronnictwo polityczne $\rightarrow$ wkluczyć

strój domowy $\rightarrow$ kokardka

strój ludowy $\rightarrow$ jicziński

strój plażowy $\rightarrow$ pan-suit

strój spodni $\rightarrow$ pan-suit

stróż porządku $\rightarrow$ policyjność

studnia artezyjska $\rightarrow$ samowypływ

stworzenie $\mathrm{z}$ niczego $\rightarrow$ popularnościowy

substancja lotna $\rightarrow$ feromon

sucha zaprawa narciarska $\rightarrow$ ceperka

surowica końska $\rightarrow$ odczulenie

surowica odpornościowa $\rightarrow$ antyferment

surowica przeciwpneumokokowa $\rightarrow$ odczulenie

sygnał morski $\rightarrow$ plaża

syn marnotrawny $\rightarrow$ kątek

szczoteczka do zębów $\rightarrow$ szpiegówka

szerokość geograficzna $\rightarrow$ poliestryczny

Szkice o Conradzie $\rightarrow$ conradologia [utwór Marii Dąbrowskiej]

szkiełko i oko $\rightarrow$ szczególik

szkło lane $\rightarrow$ marblit

szkło mleczne $\rightarrow$ dekalumen

szkolnictwo wyższe $\rightarrow$ deglomeracyjny

szkoła nowego widzenia $\rightarrow$ neosensualizm

szkoła ogólnokształcąca $\rightarrow$ polifurkacja

szkoła przyfabryczna $\rightarrow$ polifurkacja

szkoła średnia $\rightarrow$ polifurkacja

sztab generalny $\rightarrow$ arcycwał

sztab główny $\rightarrow$ podszef

Sztokholm $\rightarrow$ ataszat

szwedzko-litewski $\rightarrow$ bałtysta 
szyb osadowy $\rightarrow$ sepia

szypułka kwiatowa $\rightarrow$ plewka

śledź marynowany $\rightarrow$ śliżyk

środek odkażający $\rightarrow$ rzeżączka

środek owadobójczy $\rightarrow$ fluoroform

środek składniowy $\rightarrow$ niekoniec

świadczyć przeciwko komuś pod przysięga $\rightarrow$ cuadrillero

świat żywy $\rightarrow$ antymatematyk

światło błyskowy $\rightarrow$ flesz

światło elektryczne $\rightarrow$ połyskliwie

święta inkwizycja $\rightarrow$ antynazizm

święte słowa czyjeś $\rightarrow$ farmazoński

tabliczka czekolady $\rightarrow$ mikrostragan

tabliczka łupkowa $\rightarrow$ łupek

tabu językowe $\rightarrow$ pośmiertny

taedium vitae $\rightarrow$ butersznit

tajemnica służbowa $\rightarrow$ wtajemniczać

tak jest $\rightarrow$ odkrzyknięcie

takt trójdzielny $\rightarrow$ duola

taniec śmierci $\rightarrow$ poschły

tarcza zegarowa $\rightarrow$ wyzgrzytać

tatarak zwyczajny $\rightarrow$ fenkuł

Telefoniczna Poradnia Językowa radioreklama

temat imiesłowowy $\rightarrow$ skażoność

teoria aktów mowy $\rightarrow$ polonistyczność

teoria pola $\rightarrow$ bezźródłowy

teorja Bakoniańska $\rightarrow$ dedukować

teorja Wegenera $\rightarrow$ litosfera

Tetmajer $\rightarrow$ szmerny

Timofiejew $\rightarrow$ meteoryta

tkanina bawełniana $\rightarrow$ poszwowy

tkanina ubraniowa $\rightarrow$ poszwowy

tkanka korkotwórcza $\rightarrow$ fellogen

tkanka zębowa $\rightarrow$ podszyjkowy

tłuszcz obojętny $\rightarrow$ trójstearyna

to pewna, ... $\rightarrow$ etymolog

Tomasz $\rightarrow$ wiwlas

torebka nasienna $\rightarrow$ dojrzenie

Towarzystwo Przyjaciół Polaków $\rightarrow$ nie-lord

towarzysz broni $\rightarrow$ kurierski

tracić na znaczeniu $\rightarrow$ rozbijanie

Traktat Wersalski $\rightarrow$ nielegalnie 


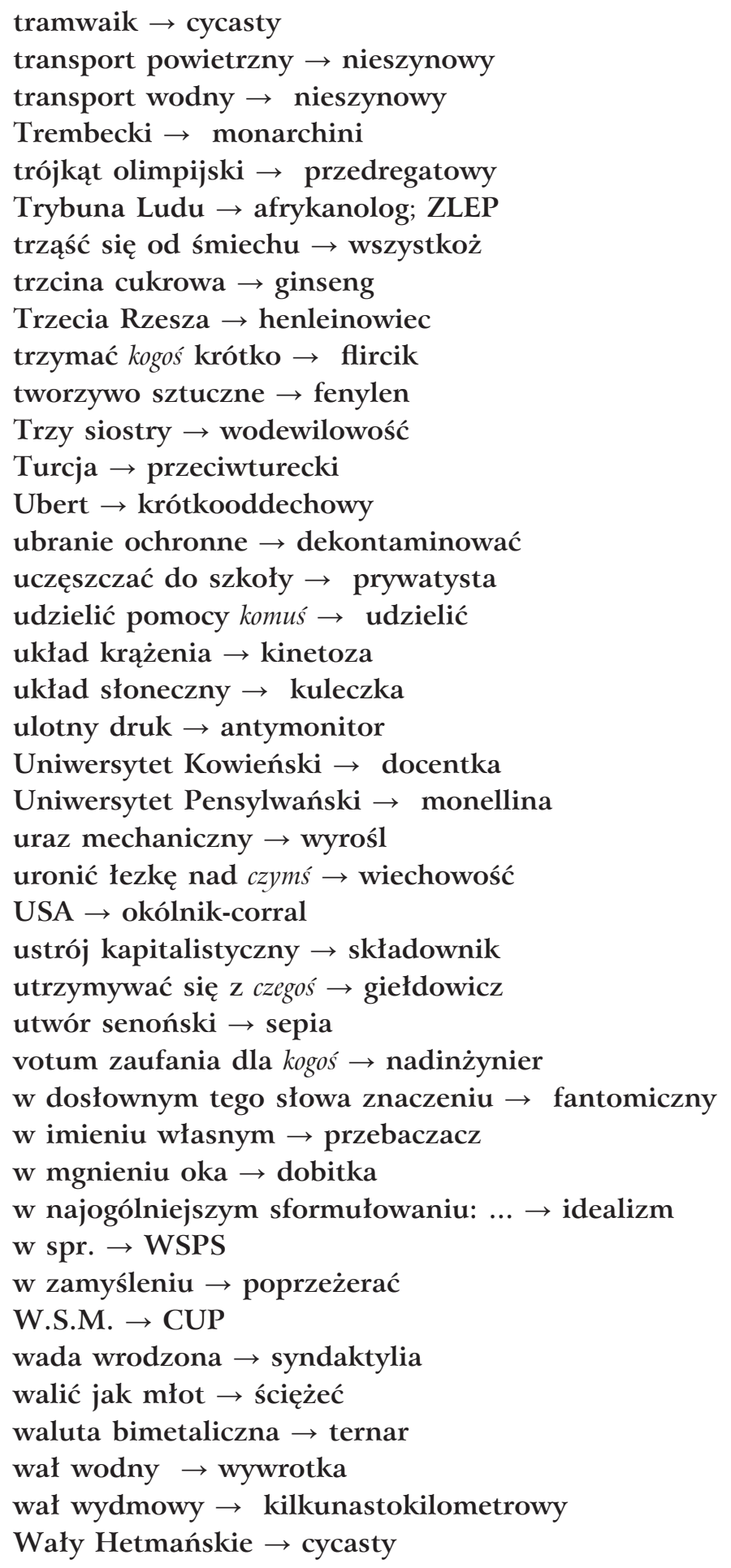


wapień ikrowcowy $\rightarrow$ oolit

wapień ziarnisty $\rightarrow$ oolit

Warszawa $\rightarrow$ kafelek; szopkarz

waśń dynastyczna $\rightarrow$ konijski

Węgierska Socjalistyczna Partia Pracy $\rightarrow$ WSPS

wiedza teoretyczna $\rightarrow$ odkrywacz

wielka dama $\rightarrow$ wszystkoż

wielka rewolucja francuska $\rightarrow$ niewąchanie

Wielkanoc $\rightarrow$ odrwić

wiertło dentystyczne $\rightarrow$ mikrotarczka

więzienie polityczne $\rightarrow$ skaryszewski

Wilhelm III Orański $\rightarrow$ wig

Wisła $\rightarrow$ crossowiec

witamina $\mathrm{B}_{12} \rightarrow$ hemopirol

Witkiewicz $\rightarrow$ cuha

coś w kształcie czegoś $\rightarrow$ kampanka

władza duchowna $\rightarrow$ podstawny

władza ludowa $\rightarrow$ titowski

własić się $\rightarrow$ włudzić się

coś w oczach czyichś $\rightarrow$ niekoniec

woda gruntowa $\rightarrow$ samowypływ

$\operatorname{coś}_{1}$ w odróżnieniu od czegoś $_{2} \rightarrow$ gęstofiltrowy

Wojewódzka Rada Narodowa $\rightarrow$ jedyneczka

Wojewódzka Spółdzielnia Pracy Usług Technicznych $\rightarrow$ WSPS

Wojewódzka Spółdzielnia Pracy Usług Wielobranżowych $\rightarrow$ WSPS

wojna światowa $\rightarrow$ kurierski

Wojskowy Sąd Rejonowy $\rightarrow$ WSPS

Wola Justowska $\rightarrow$ komorowicki

wołać kogoś w szranki $\rightarrow$ siwogłowy

wotum zaufania $\rightarrow$ centrolewy

wół tybetański $\rightarrow$ chajnak

wóz konny $\rightarrow$ niekonny

wózek górski $\rightarrow$ kruszyzna

zrobić coś $\mathbf{w}$ popłochu $\rightarrow$ flama

wskaźnik zmiany cen $\rightarrow$ deflator

komuś wstęp wzbroniony $\rightarrow$ niehindus

wśrubowywać się w coś jakoś $\rightarrow$ znurtować

wybuchać śmiechem $\rightarrow$ chichotek

wychowanie obywatelskie $\rightarrow$ politolog

Wyczółkowski $\rightarrow$ pierśnica

wydać obiad na czyjąś cześć $\rightarrow$ antymięsny

wygadywać głupstwa $\rightarrow$ pracuś 
wygłosić referat $\rightarrow$ wiernokątny

wylać coś na papier $\rightarrow$ pośpieszny

wyliczać coś na palcach $\rightarrow$ kajakowicz

wyłącznik rozruchowy $\rightarrow$ krótkozwarty

wynieść $\operatorname{kogos}_{1}$ dekretem na kogoś $_{2} \rightarrow$ dehumor

wypadki chodzą po ludziach $\rightarrow$ paniczysko

wypędzić na cztery wiatry $\rightarrow$ wlepić

wyposażenie techniczne $\rightarrow$ doinwestować

wyraz obcy $\rightarrow$ kalolit

wyrośl kostna $\rightarrow$ wyrośl

Wysoki Zamek $\rightarrow$ cycasty

wystrychnąć się na błazna $\rightarrow$ dwukrajowiec

Wyszyński $\rightarrow$ półbieda

coś wywodzi się stąd, że ... $\rightarrow$ gęstofiltrowy

za jednym zamachem $\rightarrow$ wytwórczy

ktoś zalany potem $\rightarrow$ niedźwiedzi

zabór mienia $\rightarrow$ kodeksowo

zabór pruski $\rightarrow$ wszechwęgierskość

zabór rosyjski $\rightarrow$ agentka; wszechwęgierskość

zabytek literacki $\rightarrow$ językoznawczyni

zaciskać zęby $\rightarrow$ wyżlak

zaimek względny $\rightarrow$ składniowo

Zaleski $\rightarrow$ atencyjka

załatwiać jakieś interesy $\rightarrow$ gimnazjon

zapalenie mózgu $\rightarrow$ porażenny

zapalenie płuc odoskrzelowe $\rightarrow$ kurczliwość

zapuszczać się w istotę rzeczy $\rightarrow$ geometryczność

zasada treściowa $\rightarrow$ nieeufemistyczny

zasób archiwalny $\rightarrow$ jednowziernikowy

zawrzeć alians z kimś $\rightarrow$ mosan

Zawadzki $\rightarrow$ rockefellerowski

zbiornik wodny $\rightarrow$ hygrofil

zdanie jednostkowe identyfikujące $\rightarrow$ niereferencyjny

zdanie niedystynkcyjne $\rightarrow$ kontynuatywny

zdanie przydawkowe $\rightarrow$ składniowo

zdanie względne niedystynkcyjne $\rightarrow$ kontynuatywny

zdjęcie mikrofilmowe $\rightarrow$ jednowziernikowy

zdjęcie rentgenowskie $\rightarrow$ tomograf

zdjęcie stereoradiograficzne kątowe $\rightarrow$ obiektywowy

zdjęcie warstwowe $\rightarrow$ tomograf

z dnia na dzień $\rightarrow$ pałać

zegar z kukułką $\rightarrow$ kurancik 
zespół archiwalny $\rightarrow$ jednowziernikowy

zgiaćc się we dwoje $\rightarrow$ ricmus

zgłosić interpelację $\rightarrow$ nielegalnie

zgołębić się $\rightarrow$ zgruchać się

ziemiaństwo herbowe $\rightarrow$ zeszłowieczny

Ziemie Wyzyskane $\rightarrow$ tebkarz

zima za pasem $\rightarrow$ ceperka

zjawisko historyczne $\rightarrow$ kretyńsko

zjednoczona opozycja $\rightarrow$ sflaczenie

z krwi i kości $\rightarrow$ crossowiec; cukierkowato

Złośliwe uwagi $\rightarrow$ sflaczenie

złoty reński $\rightarrow$ krajcarowy

złożenie nominalne $\rightarrow$ poprzedzać

złożyć gdzieś interpelację pod czyimś adresem $\rightarrow$ nielegalnie

zły stan zdrowia $\rightarrow$ protoscholarcha

zmarszczka nakatna $\rightarrow$ paluchowy

zmienna predykatywna $\rightarrow$ grammem

zmysł węchu $\rightarrow$ feromon

znaczek pocztowy $\rightarrow$ filatelia

znać kogoś z widzenia $\rightarrow$ wszechrozkosz

znajdować wyraz w czymś $\rightarrow$ dehumanizacyjny

znak nagłówkowy $\rightarrow$ niesinolog

znak paragrafowy $\rightarrow$ koniuczek

znak pisarski $\rightarrow$ znojnie

znak równania między $c z y m s_{1}$ i $c z y m s_{2} \rightarrow$ partokracja

zorza polarna $\rightarrow$ radiosondaż

z prawa i z lewa $\rightarrow$ antybolszewik

z jakiegoś punktu widzenia $\rightarrow$ wyznawczy

zrobić miejsce $\rightarrow$ raban

zrobić uwagę, że $\ldots \rightarrow$ geszefciarski

zrobić wywiad z kimś $\rightarrow$ wywiadzik

któryś z rzędu po czymś $\rightarrow$ honoracja

$\ldots, \mathrm{z}$ tym że ... $\rightarrow$ roztelegrafować

związek kompleksowy $\rightarrow$ chelat

związek organiczny $\rightarrow$ aryl; heksan; chelat; krenowy

Związek Polaków w Niemczech $\rightarrow$ nielegalnie

Związek Postępowo-Demokratyczny $\rightarrow$ pedecja

Związek Republik Sowieckich $\rightarrow$ duchowszczyński

zwierzę domowe $\rightarrow$ skarmiać

zwierzę hodowlane $\rightarrow$ cieliczka

zwracać jakoś uwagę $\rightarrow$ porównawczo

zwrot semantyczny $\rightarrow$ niekonny 
zwrócić czyjąs uwagę, iż $\ldots \rightarrow$ nielegalnie

zwyczaj językowy $\rightarrow$ dokroić

Zygmunt I Stary $\rightarrow$ ternar

zyskać jakąs popularność $\rightarrow$ nowy

źrenica oka u kogoś $\rightarrow$ paniątko

źródło historyczne $\rightarrow$ policki

Żabcio $\rightarrow$ skok

żarówka błyskowa $\rightarrow$ flesz

że tak powiem $\rightarrow$ kinoterapia

żelazo prętowe $\rightarrow$ płoza

żelazo sztabowe $\rightarrow$ płoza

żółw leśny $\rightarrow$ motel

żukowski $\rightarrow$ daleczny

żur owsiany $\rightarrow$ śliżyk

życie gospodarcze $\rightarrow$ jednowziernikowy

życie na progu $\rightarrow$ antyforma

życie niemoralne $\rightarrow$ koczotka

życie pierwotne $\rightarrow$ wpółziemny

życie seksualne $\rightarrow$ antymanichejski

życie społeczne $\rightarrow$ metapoziom

\section{Czy NFJP dezinformuje?}

To zaskakujące pytanie. Z reguły autorzy słowników nie podnoszą takiego problemu, mówiąc o własnym dziele. Współcześnie, kiedy się słyszy czy widzi w druku rzeczownik dezinformacja, to nasuwają się dwie możliwości interpretacyjne: albo nadawcy idzie w danej sytuacji o fałszywą, nieprawdziwą, mylącą informację, albo o czynność polegającą na mylnym informowaniu kogoś. Proces mylnego informowania implikuje złą wolę wykonawcy czynności. Udział złej woli wydaje się być zjawiskiem niepowszechnym, ale nie niemożliwym w świecie współczesnych słowników; czynnik złej woli na pewno istnieje i zasługuje na uwagę oraz analizę, zwłaszcza w perspektywie historycznej. Najczęściej, jak się wydaje, autorzy słowników dezinformują niechcący, mimowolnie, rozmijając się z prawdą z różnych powodów: własnej niewiedzy, trudności w dotarciu do wiedzy bądź lenistwa. O istnieniu zjawiska tej mniej nagannej dezinformacji świadczą, specyficznie, pozytywnie, dołączane do niektórych, zwłaszcza większych, słowników erraty. Studiowanie errat jest pożyteczne, co więcej: jest konieczne, pouczające, jeśli leksykografię ma cechować akrybia i jeśli chce się mówić o „maestrii leksykografa” 10 .

${ }^{10} \mathrm{O}$ tym unikatowym wyrażeniu por. informację w internecie. 
O znaczeniu errat, szczegółowym i ogólniejszym, na przykładzie słownika Doroszewskiego jest mowa w pracy: Wawrzyńczyk 2016. Odnotowuje ona między innymi fakt niewyjątkowości informacji sprzecznych w odniesieniu do cytatów użytych więcej niż jeden raz: kiedy to dany cytat, powtórzony w innym artykule hasłowym, ma nieidentyczne brzmienie i nieidentyczny adres bibliograficzny (zwykle idzie o numer strony w tekście źródłowym).

Dezinformacji zamierzonych NFJP nie zawiera. Informacje sprzeczne, rozumiane jako dezinformacje mimowolne, w materiałach NFJP są obecne. Kontrolujemy jednak te materiały pod kątem erratologicznym nieustannie, systematycznie, sygnalizując defektywność haseł tam, gdzie ma ona miejsce. Obfitość danych NFJP sprawia, że usunięcie z niego wszystkich informacji sprzecznych mimowolnych zajmie nam jeszcze nieco czasu. 


\section{Bibliografia}

\section{Podstawowa literatura przedmiotu ${ }^{1}$}

Bajerowa, Irena 2003. Zarys historii języka polskiego 1939-2000. Warszawa: Wydawnictwo Naukowe PWN.

Bańczerowski, Jerzy 2020. Glottotronika: nieuchronna faza lingwistyki (lingwistyczna science fiction?). W: K. Wojan (red.), Wokót pewnego cytatu. Zbiór artykułów. Warszawa: BEL Studio, s. 25-39.

Bańkowski, Andrzej 2000. Etymologiczny stownik języka polskiego. T. 1: A-K. Warszawa: Wydawnictwo Naukowe PWN.

Bańkowski, Andrzej 2000a. Etymologiczny stownik języka polskiego. T. 2: L-P. Warszawa: Wydawnictwo Naukowe PWN.

Bańkowski, Andrzej 2014. Etymologiczny stownik mowy polskiej. T. 3, cz. 1. Częstochowa: Linguard.

Bogusławski, Andrzej 1988. Język w słowniku. Desiderata semantyczne do wielkiego słownika polszczyzny. Wrocław etc.: Zakład Narodowy im. Ossolińskich.

Bogusławski, Andrzej 2008. Semantyka, pragmatyka. Leksykografa głos demarkacyjny. Warszawa: Takt. Bogusławski, Andrzej 2020. Lingwistyczna teoria mowy. Warszawa: Wydawnictwa Uniwersytetu Warszawskiego [w druku].

Bogusławski, Andrzej, Danielewiczowa, Magdalena 2005. Verba polona abscondita. Sonda stownikowa III. Warszawa: Elma Books.

Bogusławski, Andrzej, Garnysz-Kozłowska, Teresa 1979. Addendum to Polish phraseology. An introductory issue. Addenda do frazeologii polskiej. Zeszyt wstepny. Edmonton: Linguistic Research.

Bogusławski, Andrzej, Wawrzyńczyk, Jan 1993. Polszczyzna, jaka znamy. Nowa sonda słownikowa. Warszawa: Katedra Lingwistyki Formalnej UW.

Buttler, Danuta 1974. Polski dowcip językowy. Wyd. 2. Warszawa: Państwowe Wydawnictwo Naukowe. Buttler, Danuta 1978. Powojenne innowacje w polskim zasobie słownym. Przegląd Humanistyczny, 22(5), s. 55-67.

Buttler, Danuta 1980. Powojenne ekspresywizmy polskie. Prace Filologiczne, 29, s. 85-90.

Dąbrowska, Klara 1957. Neologizmy słowotwórcze w publicystyce polskiej okresu Odnowy. Zeszyty Naukowe WSP w Opolu, 4, Językoznawstwo, 1, s. 39-99.

${ }^{1}$ Wykaz rejestruje równocześnie wszystkie znane nam publikacje poświęcone w większym czy mniejszym stopniu fotoleksykografii języka polskiego. Dorobek fotoleksykograficzny, zarówno w formie druków, jak i tekstów elektronicznych (dostępnych m.in. na platformie ResearchGate) powiększa się stale, regularnie, od 2008 r. Lata najbliższe, do 2022 włącznie, przyniosą na pewno jego potrojenie. 
Doroszewski, Witold (red.) 1958-1969. Słownik języka polskiego. T. 1-11. Warszawa: Wiedza Powszechna, Państwowe Wydawnictwo Naukowe.

Górny, Mirosław, Wierzchoń, Piotr 2010. Polish Digital Libraries as a Philologist's Tool: Based on 666 Adjectives from the Digital Library of Wielkopolska. Poznań: Sorus.

Iwanowski, Marek 2009. Fotoaddenda do leksykografii polskiej. Warszawa: BEL Studio.

Iwanowski, Marek 2010. Nowe stownictwo polskie? Fotomateriaty z prasy lat 2001-2010. WarszawaŁódź: Semiosis Lexicographica, Instytut Rusycystyki UŁ.

Iwanowski, Marek 2010a. Einführung in die Validation des „Polnisch-deutschen Wörterbuchs der Neologismen”, Harrassowitz Verlag 2007. Łask -Warszawa: Leksem.

Iwanowski, Marek (oprac.) 2010. Depozytorium leksykalne języka polskiego. Nowe fotomateriały z lat 1901-2010. T. 6. Warszawa: BEL Studio.

Jadacka, Hanna 2001. System stowotwórczy polszczyzny (1945-2000). Warszawa: Wydawnictwo Naukowe PWN.

Jankowski, Michał, Wawrzyńczyk, Jan, Wierzchoń, Piotr 2019. 330330 polskich słów. Indeks a tergo. Warszawa: BEL Studio.

Kokowski, Władysław 1903. Słownik ortograficzny języka polskiego. Warszawa-Lódź: nakł. L. Fiszera.

Małek, Eliza 2008. Ku fotoleksykografii. Łódź: Instytut Rusycystyki UŁ.

Małek, Eliza (oprac.) 2011. Depozytorium leksykalne języka polskiego. Nowe fotomateriały z lat 19012010. T. 9. Warszawa: BEL Studio.

Małek, Eliza, Wawrzyńczyk, Jan 2010. Fotoglosy do rejestrów wspótczesnego słownictwa polskiego. Łódź: Instytut Rusycystyki UŁ.

Małek, Eliza, Wawrzyńczyk, Jan 2010a. Wokót kwestii komponentów latentnych informacji leksykograficznej $w$ Wielkiej encyklopedii PWN. Warszawa-Lódź: Semiosis Lexicographica, Instytut Rusycystyki UŁ.

Mańczak, Witold, Wawrzyńczyk, Jan (red.) 2009. Prawda-prawdy-mity-fatsze w językoznawstwie. Warszawa: Takt.

Miodek, Jan 1976. Syntetyczne konstrukcje leksykalne w języku polskim. Wrocław: Zakład Narodowy im. Ossolińskich.

Müldner-Nieckowski, Piotr 2007. Frazeologia poszerzona. Studium leksykograficzne. Warszawa: Oficyna Wydawnicza Volumen.

Nowakowska, Beata 2005. Nowe połaczenia wyrazowe we wspótczesnej polszczyźnie. Kraków: Lexis.

Pałka, Patrycja, Kwaśnicka-Janowicz, Agata 2017. Przewodnik po elektronicznych zasobach językowych dla polonistów (słowniki, kartoteki, korpusy, kompendia). Kraków: Towarzystwo Miłośników Języka Polskiego.

Skorupka, Stanisław 1977. Stownik frazeologiczny języka polskiego. T. 1-2. Wyd. 3. Warszawa: Wiedza Powszechna.

Smółkowa, Teresa 1976. Nowe słownictwo polskie. Badania rzeczowników. Wrocław etc.: Zakład Narodowy im. Ossolińskich.

Smółkowa, Teresa (red.) 2013. SŁOWA, słowa... Czy je znasz?. Kraków: Instytut Języka Polskiego PAN.

Smółkowa, Teresa, Tekiel, Danuta 1977. Nowe słownictwo polskie. Przymiotniki i przysłówki. Wrocław etc.: Zakład Narodowy im. Ossolińskich.

Tekiel, Danuta (red.) 1988. Nowe stownictwo polskie. Materiaty z prasy lat 1972-1981. Cz. I: A-O. Wrocław etc.: Zakład Narodowy im. Ossolińskich.

Tekiel, Danuta (red.) 1989. Nowe stownictwo polskie. Materiaty z prasy lat 1972-1981. Cz. II: P-Z, Wrocław etc.: Zakład Narodowy im. Ossolińskich.

Waszakowa, Krystyna 2010. Czy jeszcze można, wypada, warto zajmować się neologizmami? (w związku z fotodokumentacyjną metodą badawczą Piotra Wierzchonia). W: I. Burkacka, R. Pawelec, 
D. Zdunkiewicz-Jedynak (red.), Słowa - kładki, na których spotykają się ludzie różnych światów. Warszawa: Wydział Polonistyki UW, s. 193-207.

Wawrzyńczyk, Andrzej (oprac.) 2010. Depozytorium leksykalne języka polskiego. Nowe fotomateriaty z lat 1901-2010. T. 4. Warszawa: BEL Studio.

Wawrzyńczyk, Jan 1987. W sprawie materiałów do tezaurusa polszczyzny dwudziestowiecznej. Łódź: Uniwersytet Łódzki.

Wawrzyńczyk, Jan 1989. Nad Słownikiem języka polskiego 1958-1969. Toruń: Instytut Filologii Słowiańskiej UMK.

Wawrzyńczyk, Jan 1993. Uwagi o rejestracji neologizmów polszczyzny dwudziestowiecznej. W: W. Lubaś, F. Sowa (red.), Wokót słownika współczesnego języka polskiego. III: Zakres selekcji i informacji. Kraków: Instytu Języka Polskiego PAN, s. 33-40.

Wawrzyńczyk, Jan 1994. Tak zwane nowe stownictwo polskie w świetle dokumentacji „Polskiego Informatorium Wyrazowego”. Katowice: Śląsk.

Wawrzyńczyk, Jan 1995. O wyrażeniach niehasłowych w Słowniku języka polskiego pod redakcja Witolda Doroszewskiego. Z wyborem przykładów. Częstochowa: Wyższa Szkoła Pedagogiczna.

Wawrzyńczyk, Jan 1999. Nowe stownictwo polskie. Fikcje i fakty. Warszawa: Instytut Informacji Naukowej i Studiów Bibliologicznych UW.

Wawrzyńczyk, Jan 2000-2012. Słownik bibliograficzny języka polskiego. Wersja przedelektroniczna. T. 1-10. Warszawa: BEL Studio.

Wawrzyńczyk, Jan 2009. Autosuplement do Stownika warszawskiego. Poznań: Sorus.

Wawrzyńczyk, Jan 2009a. W poszukiwaniu nowego stownictwa polskiego. Materiały z prasy lat 1932-1933. Łódź: Instytut Rusycystyki UŁ.

Wawrzyńczyk, Jan 2010. Inny „Doroszewski”. Łask: Leksem.

Wawrzyńczyk, Jan 2011. Stownictwo nowopolskie. Redatacje. Warszawa: BEL Studio.

Wawrzyńczyk, Jan 2013-2015. Depozytorium leksykalne języka polskiego. T. 41-44: Fotoprzegląd frazematyczny. T. 1-4. Warszawa: BEL Studio.

Wawrzyńczyk, Jan 2013-2016. 250 tysięcy ciekawych stów. Leksykon przypomnień. T. 1-8. Warszawa: BEL Studio.

Wawrzyńczyk, Jan 2014-2015. Fotocytatografia polska. Koniec XVIII - początek XXI w. T. 1-4. Warszawa: BEL Studio.

Wawrzyńczyk, Jan 2015. 300 tysięcy czy milion(y)?. O stanie zasobów stownictwa polskiego w dniu 31 grudnia 2000 roku. Warszawa: Mila Hoshi.

Wawrzyńczyk, Jan 2016. Opowiastki o „Słowniku Doroszewskiego” (z zasobów strony www.nfjp.pl wysnute). Warszawa: Wydawnictwo Literackie Białe Pióro.

Wawrzyńczyk, Jan 2016a. Z leksykografii polskiej i obcej. Szkice, uwagi, polemiki. Warszawa: BEL Studio.

Wawrzyńczyk, Jan 2019. Nowa sonda hasłownikograficzna Piotra Wierzchonia. Studia Rossica Gedanensia, 6, s. 272-276.

Wawrzyńczyk, Jan 2019a. Notatka w kwestii samodezinformacji i zjawisk pokrewnych - na przykładach ze środowiska „Poradnika Językowego”. Poradnik Językowy, 1, s. 117-119.

Wawrzyńczyk, Jan (red.) 2009. Czterdzieści lat minęło... nad „Słownikiem Doroszewskiego”. Warszawa: Takt.

Wawrzyńczyk, Jan, Wierzchoń, Piotr 2016. 300 tysięcy polskich stów. Indeks a fronte. Poznań: Sorus.

Wawrzyńczyk, Jan, Wierzchoń, Piotr (red.) 2017. Wokół 300 tysięcy polskich stów. Wstęp do hastownikologii. Warszawa: BEL Studio.

Węglarz, Jan 1981. Sterowanie w systemach typu kompleks operacji. Warszawa-Poznań: Państwowe Wydawnictwo Naukowe.

Wierzchoń, Piotr 2008. ANTI. Poznań: Instytut Językoznawstwa UAM. 
Wierzchoń, Piotr 2008a. Fotodokumentacja, chronologizacja, emendacja. Teoria i praktyka weryfikacji materiatu leksykalnego w badaniach lingwistycznych. Poznań: Instytut Językoznawstwa UAM.

Wierzchoń, Piotr 2008b. Jaskółki przejawów internacjonalizacji w słowotwórstwie współczesnej polszczyzny w materiałach z lat 1894-1984. Tylko sto przykladów. Łask: Leksem.

Wierzchoń, Piotr 2008c. KOTUŚ. „,Verba polona abscondita...” (w fotodokumentacji). Szkic lingwochronologizacyjny. Centuria pierwsza. Poznań: Instytut Językoznawstwa UAM.

Wierzchoń, Piotr 2009. 444 przysłówki z tekstów okresu 1900-1939 nieobecne w Słowniku języka polskiego pod red. W. Doroszewskiego. Fotosuplement (etiuda letnia). W: J. Wawrzyńczyk (red.), Czterdzieści lat minęło... nad „Stownikiem Doroszewskiego”. Warszawa: Takt, s. 69-254.

Wierzchoń, Piotr 2009a. Dlaczego fotodokumentacja? Dlaczego chronologizacja? Dlaczego emendacja? Instalacja gazowa, parking podziemny $i$,,odległość niezerowa”. Poznań: Instytut Językoznawstwa UAM.

Wierzchoń, Piotr 2010. Depozytorium leksykalne języka polskiego. Nowe fotomateriaty z lat 1901-2010. T. 1. Warszawa: BEL Studio.

Wierzchoń, Piotr 2010a. Torując drogę teorii lingwochronologizacji. Investigationes Linguisticae, 20, s. $105-185$.

Wierzchoń, Piotr 2011. Depozytorium leksykalne języka polskiego. Nowe fotomaterialy z lat 1901-2010. T. 2. Warszawa: BEL Studio.

Wierzchoń, Piotr 2012. Depozytorium leksykalne języka polskiego. Nowe fotomateriały z lat 1901-2010. T. 3. Warszawa: BEL Studio.

Wierzchoń, Piotr 2014. Depozytorium leksykalne języka polskiego. T. 11-40: Fotosuplement do Stownika warszawskiego. Warszawa: BEL Studio.

Witas, Piotr 2012. Na przykład prorosyjski... Kartka z dziejów polskiej leksykografii teoretycznej i praktycznej. Warszawa: BEL Studio.

Wróblewski, Henryk (oprac.) 2011. Depozytorium leksykalne języka polskiego. Nowe fotomateriały z lat 1901-2010. T. 7. Warszawa: BEL Studio.

Zagrodnikowa, Alicja 1982. Nowe wyrazy i wyrażenia w prasie. Kraków: Ośrodek Badań Prasoznawczych.

Zombirt, Andrzej (oprac.) 2010. Depozytorium leksykalne języka polskiego. Nowe fotomateriaty z lat 1901-2010. T. 5. Warszawa: BEL Studio.

\section{Prace na temat NFJP}

Borchmann, Łukasz 2018. Narodowy Fotokorpus Języka Polskiego: od materiatu drukowanego do elektronicznego stownika demonstracyjnego z poświadczeniem fotocytatowym. Poznań: Instytut Językoznawstwa UAM. Praca nieopublikowana.

Borchmann, Łukasz, Dzienisiewicz, Daniel, Wierzchoń, Piotr 2017. From printed materials to electronic demonstrative dictionary - the Story of the National Photocorpus of Polish and its Korean and Vietnamese descendants. W: I. Kosem, C. Tiberius, M. Jakubíček, J. Kallas, S. Krek, V. Baisa, (ed.), Electronic Lexicography in the 21st century: Proceedings of eLex 2017 Conference, 19-21 September 2017. Leiden: Lexical Computing CZ s.r.o., pp. 680-702.

Kozłowska, Anna 2020. O możliwościach wykorzystania Narodowego Fotokorpusu Języka Polskiego w badaniach neologizmów pisarzy (na przykładzie języka Cypriana Norwida). W: K. Wojan (red.), Wokót pewnego cytatu. Zbiór artykułów. Warszawa: BEL Studio, s. 167-172.

Wawrzyńczyk, Jan 2014. Język, literatura i kultura rosyjska na stronie www.nfjp.pl. Warszawa: Mila Hoshi. Wawrzyńczyk, Jan 2014. Русский язык на сайте www.nfjp.pl. Studia Rossica Gedanensia, 1, s. 159-163. 
Wawrzyńczyk, Jan 2014e. Stownik frazeologiczny polszczyzny XIX wieku. Fotodokumentacja z zasobów www.nfjp.pl (1-250). Warszawa: Mila Hoshi.

Wawrzyńczyk, Jan 2015. Fotocytatografia polska - nowsze derywaty odfrazematyczne (w zasobach www.nfjp.pl). Warszawa: Mila Hoshi.

Wawrzyńczyk, Jan 2015a. Język, literatura i kultura węierska na stronie www.nfjp.pl. Warszawa: Mila Hoshi.

Wawrzyńczyk, Jan 2015b. O czasownikowości polszczyzny (w świetle tekstów Zygmunta Krasińskiego ze strony www.nfjp.pl). Warszawa: Mila Hoshi.

Wawrzyńczyk, Jan 2015c. Przegląd tereferyzmów datacyjnych (w świetle danych strony www.nfjp.pl). Warszawa: Mila Hoshi.

Wawrzyńczyk, Jan 2015d. Triada: antypolonizm - 'antypolonizm' - antypolonizm (przypisek do strony www.nfjp.pl). Łódź: Philologica.

Wawrzyńczyk, Jan 2015e. Stownik frazeologiczny polszczyzny XIX wieku. Fotodokumentacja z zasobów www.nfjp.pl (251-500). Warszawa: Mila Hoshi.

Wawrzyńczyk, Jan 2015f. Stownik frazeologiczny polszczyzny XIX wieku. Fotodokumentacja z zasobów www.nfjp.pl (501-750). Warszawa : Mila Hoshi.

Wawrzyńczyk, Jan 2016. Magyar nyelv, irodalom és kultúra a www.nfjp.pl honlapon. Warszawa: Mila Hoshi.

Wawrzyńczyk, Jan 2016a. Nasze drobne kompensacje leksykograficzne, czyli jak wzbogacamy zasoby strony www.nfjp.pl. Warszawa: Mila Hoshi.

Wawrzyńczyk, Jan 2016b. 1000 stów zadośćuczynienia (Wypiski ze strony www.nfjp.pl). Warszawa: Wawrzyn.

Wawrzyńczyk, Jan 2017. Nowe informacje o zbiorach «Narodowego Fotokorpusu Języka Polskiego». Warszawa: BEL Studio.

Wawrzyńczyk, Jan 2020. Polskolondyńskie druki ulotne i okolicznościowe w zasobach «Narodowego Fotokorpusu Języka Polskiego». Warszawa: BEL Studio.

Wawrzyńczyk, Jan 2020a. Przeglad grafojednostek ze spacja wewnętrzna w zasobach «Narodowego Fotokorpusu Języka Polskiego». Warszawa: nakł. własnym.

Wawrzyńczyk, Jan (oprac.) 2017. Gabrysi i innym licealistkom o «Narodowym Fotokorpusie Języka Polskiego». Warszawa: Wawrzyn.

Wawrzyńczyk, Jan, Wierzchoń, Piotr 2016. О проекте «Национального фотокорпуса польского языка» (www.nfjp.pl). Warszawa: Peter Nayboen.

Wawrzyńczyk, Jan, Wierzchoń, Piotr 2017. How to revolutionize the technology of dictionary-making. Вестник Московского ун-та, 22(2), pp. 94-104.

Wawrzyńczyk, Jan, Wierzchoń, Piotr 2017. Konstrukcje syntetyczne w zasobach «Narodowego Fotokorpusu Języka Polskiego». Warszawa: Peter Nayboen.

Wawrzyńczyk, Jan, Wierzchoń, Piotr 2017a. Podstawowe informacje o «Narodowym Fotokorpusie Języka Polskiego». Warszawa: BEL Studio.

\section{Inne publikacje (nawiq̨zujące do NFJP)}

Dzienisiewicz, Daniel, Wierzchoń, Piotr 2016. On the japaneseness of Polish: A linguochronological approach. Opuscula Iaponica \& Slavica, 3, pp. 53-76.

Dzienisiewicz, Daniel, Borchmann, Łukasz, Wierzchoń, Piotr, Graliński, Filip 2018. Re-research.pl: Where humanities meet computer science. Computational Methods in Science and Technology, 23(1), pp. 7-19. 
Gorzkowicz, Justyna 2020. PUNO - niezależne szkolnictwo polskie poza granicami Kraju. Londyński wpis do sztambucha. W: K. Wojan (red.), Wokót pewnego cytatu. Zbiór artykutów. Warszawa: BEL Studio, s. 117-120.

Кульпина, Валентина Г., Татаринов, Виктор А. 2020. Профессор Ян Вавжинчик - основатель оригинальных жанров лексикографии и библиографии и законодатель лексикографических мод. W: K. Wojan (red.), Wokót pewnego cytatu. Zbiór artykułów. Warszawa: BEL Studio, s. 195-207.

Waszakowa, Krystyna 2020. Osiągnięcia polskiej leksykografii chronologizacyjnej (refleksje z perspektywy słowotwórczej). W: K. Wojan (red.), Wokół pewnego cytatu. Zbiór artykułów. Warszawa: BEL Studio, s. 427-447.

Wawrzyńczyk, Jan 2014. Dziewiętnastowieczne słownictwo polskie w perspektywie fotoleksykograficznej. Łódź: Elja Malek.

Wawrzyńczyk, Jan 2016. Z e-brudnopisów Słownika bibliograficznego języka polskiego (Ku pótmilionowemu szybkiemu rejestrowi hasel). Warszawa: Mila Hoshi.

Wawrzyńczyk, Jan 2018. Hipersłownik-гиперсловарьhyperdictionary. Warszawa: Mila Hoshi.

Wawrzyńczyk, Jan 2018a. Moje delectabilia fotoleksykograficzne. Warszawa: Mila Hoshi.

Wawrzyńczyk, Jan 2019. Stownik polszczyzny XIX wieku. Rejestr jednostek, konteksty, lokalizacje (Projekt publikacji). Warszawa: BEL Studio.

Wawrzyńczyk, Jan (wyb.) 2017. Z miriad polskich słów (1-250). Varia, 1901-2016. Wrocław: Ata-Druk.

Wawrzyńczyk, Jan (wyb.) 2017a. Z miriad polskich stów (251-500). Varia, 1901-2017. Warszawa: Wawrzyn.

Wawrzyńczyk, Jan (wyb. i oprac.) 2018. Fotoleksykografia ciekawa i użyteczna. Warszawa: BEL Studio. Witas, Piotr P. 2020. Polska leksykografia - „szok przyszłości” - Big Data. Rzecz zasadniczo o redatant(k)ach. W: K. Wojan (red.), Wokól pewnego cytatu. Zbiór artykułów. Warszawa: BEL Studio, s. 449-467.

Шкапенко, Татьяна М., Вавжинчик, Ян, Вежхонь, Петр 2019. Фотодокументация и гипертекстуализация как новые направления польской лексикографии. W: Слово и словарь $=$ Vocabulum et voacularium: сборник научных статей. Минск: Беларуская наука, с. 124-130.

Вавжинчик, Ян 2019, Новое в польской лексикографии. Вестник Московского ун-та, 9, Филология, 6 , c. 152-163.

\section{W Internecie}

http://wsjp.pl 


\section{Fotomateriały. Świadectwo danych z roku $1898^{1}$}

Oto skromny wybór ilustracyjny ciekawszych haseł jedno- i wielosegmentowych. Część ich odnotowują słowniki ogólne tylko z dokumentów XX wieku, część słowników odnotowuje hasła XIX-wieczne, ale - z jakichś względów ${ }^{2}$ - bez potwierdzeń cytatowych. Jeszcze inna część przytoczonych niżej przykładowo tworów to agnonimy słownikowe. Jednostek wszystkich tych trzech rodzajów nasza fotocytatografia, zmierzająca ku ekscerpcji totalnej, nagromadziła już wiele. Dokumentacja styku wieku XIX i XX nie zaskakuje jakimś nagłym, nadzwyczajnym i znacznym przyrostem danych. Obserwujemy raczej równomierny, „spokojny” rozwój ilościowy słownictwa aż do wybuchu I wojny światowej.

Nasze materiały XIX-wieczne umożliwią gruntowną weryfikację (falsyfikację) licznych sądów datacyjnych sformułowanych na temat najrozmaitszych tematycznie i etymologicznie grup słownictwa, które trafiło do słowników dopiero w wiekach XIXXX. Sądy te rozproszone są w setkach publikacji naukowych, słownikach, monografiach, zbiorach artykułów itp. Tylko niewielką część z nich mogliśmy wymienić w Bibliografii, koncentrując się na pozycjach najbardziej inspirujących $z$ punktu widzenia procesu rechronologizacji ${ }^{3}$.

Rechronologizacja danych z okresu 1901-2000 i, w szczególności, danych zgromadzonych przez badaczy w drugiej połowie XX wieku (por. Dąbrowska 1957; Zagrodnikowa 1982; Smółkowa 1976; Smółkowa, Tekiel 1977 i wiele innych prac) to zadanie, rzec można bez przesady, gigantyczne. Niemal zupełnie nie budziły i nadal nie budzą większego zainteresowania badaczy losy związków wyrazowych, choć to

${ }^{1}$ Wybór tego roku, schyłkowego dla wieku XIX, nie jest przypadkowy; por. Wawrzyńczyk 2019.

${ }^{2}$ Które zasługują na zbadanie.

3 W którym wagę szczególną uzyskał problem tzw. tereferyzmów datacyjnych; por. Wawrzyńczyk 2015c, Witas 2012. Są wśród nich zarówno pojedyncze wyrazy, jak i związki wyrazowe. Obszerna seria prac badawczych zainicjowana w połowie lat siedemdziesiątych XX w. opracowaniami: Smółkowa 1976, Smółkowa, Tekiel 1977 tylko wyjątkowo brała pod uwagę związki wyrazowe. Na ów dorobek złożyła się kolekcja kilkunastu tysięcy cytatów, ekscerpowanych ręcznie, które były podstawą opracowania: Nowakowska 2005, analizującego połączenia wyrazowe, ale wyjątkowa szczupłość bazy materiałowej nie mogła wówczas przynieść zadowalających - z punktu widzenia tzw. małej diachronii - wyników. 
one właśnie, a nie pojedyncze grafowyrazy (byty bez spacji wewnętrznych), tworzą prymarną statystycznie masę mowy, każdej rozwiniętej mowy. Polszczyzna z jej przebogatą literaturą pisaną i drukowaną, w ostatnich latach także e-drukowaną, jest taką właśnie mową (por. Bogusławski 2020).

Dużą liczbą fotocytatów odnoszących się do tego samego hasła ${ }^{4}$ akcentujemy tutaj nasz potencjał ekscerptorski, potwierdzający bogactwo użyć poszczególnych wyrażeń, różnorodność kontekstów składniowo-znaczeniowych haseł, której skali żaden z dotychczas wydanych słowników nie ukazuje, żaden badacz nie jest w stanie wydobyć. Obfitość danych końca wieku XIX zapowiada znakomite „fotocytatołowy” na terenie XX wieku, co dokumentuje NFJP.

${ }^{4}$ Por. niżej m.in. hasło ankieta z dziesiątkami interesujących fotocytatów, których analiza może stać się przedmiotem specjalnego studium semantyczno-syntaktyczno-pragmatycznego. Dla tego rodzaju prac ważna jest odpowiednia, jak największa liczba potwierdzeń cytatowych. Udostępniamy je w niniejszym tomie obecnie, ponieważ do NFJP trafić będą mogły dopiero w przyszłości, po uzyskaniu odpowiednich środków budżetowych niezbędnych na rozbudowę naszego fotokorpusu, stworzonego w okresie 2014-2020. 
amator

zaslużył na drugą nagrodę. Jeden zaś ze znanych wyścigoweów wpadł na niezbyt odpowiedni lecz dosyé oryginalny pomyst: kostjum miał wyścigowy, maszynę okręconą różnokolorową materja a nad kierownikiem łuk, z pizodu którego był napis „amator“ $\mathrm{z}$ drugiej zaś strony .. bierze tylko pieniądze", które mialy imitować powieszone rozmaitej wielkości woreczki; W ramie widnial napis: „patent na amatora“.

ankier

\% Ankier, Ankra, także kotew albo zwora, jest to żelazo słuyące do związania ze sobą części budynku n. p. belki z murem albo ściany ze ścianą. Zob. Zegar.

\section{ankieta $^{1}$}

- Ankiela w sprawie załoźenia rzeżni i targo
wicy na bydlo opasowe w Podgórzu odbyla się
w ostatnią ́́rodę w podgórskim Magistracie przy udziale
posla Hermana Czecza, burmistrza p. Garbaczyńskie
go, reprezentantów gminy oraz grona osób facliowych.

\footnotetext{
${ }^{1}$ Ten ważny współcześnie wyraz został przypisany chronologicznie przez Andrzeja Bańkowskiego ogólnikowo drugiej połowie wieku XIX (Bańkowski 2000). Autor, jeden z pierwszych etymologów polskich, który chronologię słownictwa traktuje bardzo skrupulatnie, co znaczy, że podaje w poszczególnych artykułach hasłowych niemal zawsze daty roczne, w tym wypadku nie dysponował, jak widać, dokładnymi danymi. Wysiłki A. Bańkowskiego w zakresie chronologizacji są bardzo cenne, godne najwyższego uznania, ale ich mankamentem jest zbyt duże przywiązanie do datacji słownikowych, opieranie się na danych zwłaszcza tzw. słowników narodowych. Absolutne pierwszeństwo należy dawać w pracach (re)chronologizacyjnych datowanym tekstom, a nie słownikom. Słowniki ogólne języka polskiego są przez chronologizatorów notorycznie przeceniane, traktowane jako dzieła autorytatywne. A przecież nie istnieje do dziś żaden słownik ogólny - od „Lindego” do „Dubisza” - który by był czymś więcej niż świadectwem cząstkowego jedynie rozeznania autora czy autorów w rzeczywistym bogactwie leksyki polskiej (por. Wawrzyńczyk 2010, Wawrzyńczyk 2009).
} 
za niewłaściwe, gdyz sq̨d o tem, co będzie zamieszczonem w ty m wyeiągu, a co opuszcz onem zostauie, nie powinien byé pozostawiony trzeciej osobie, ktúra przez dowolne wypuszczenia może tendzncyjnie wypaczyc myśl zeznającego. Było-by telly pożądanem, ażeby wybituiejsi ludzie polityczni, którzy składali swoje zeznania w owej ankiecio, oglosili autentyczny tekst tych zeznań na podstawie stenogramów i w ten sposób uchronili się od przedstawienia swej opinii w błędnem świetle, albo też, aby wplynęli na stowarzyszenie urządzajg̨ce aukietę, iżby doslowny tekst zezuaí ogloszony został w sprawozdaniu $z$ ankiety.

\section{Starzy kawalerowie. Ankieta. XVII.}

Chcecie panstwo wiedzieć, co mówi djur-

myśl zeznającego. Bylo-by tedly pożądanem, ażeby wybituiejsi Indzie polityczni, którzy składali swoje zeznania w owej ankiecio, oglosili autentyczny tekst tych zeznań na podstawie stenogramów i w ten sposób uchronili się od przedstawienia swej opinii w błędnem świetle, albo też, aby wplynęli na stowarzyszenie urządzające ankietę, iżby doslowny tekst zezuaí ogluszony zostal w sprawozdaniu $z$ ankiety.

Niezmiernie ciekawą i doniosį̨̧ kwestyę poruszylo w ostatnich trzech numerach „Zdrowie*. Pan Zdzisław Kowalski, student medycyny, oglosil w niem studyum: „O stanie zdrowis i warunkach hygienicznych studentów uniwersytetu warszawskjego “, któr̨̧ oparł na przeprowadzonej na wlasną rękę ankiecie zdrowia i warunków byta 300 studentow warszawskich (z ogólnej cyfry 705 ). Za pomoç̨ kwestyonarynsza z 71 zapytań, pan K. zebral szereg bardzo pouczających cyfr i faktów. „Zdrowie jednostek w summie - to zdrowie pokolenis, zdrowie pokolek - to rozwój narodu, niezdrowio - to jego zwyrodnienie

opiewa aforyzm d-ra Nusbaums, przytoezony przez p. $\dot{\mathbf{K}}$, zas Jędrzej Śniadecki powiada: .Ten tylko doskonałym nazwac się może, kto w czerstwem i ksztułtnem ciele czyste nosi serce i niepokalaną ma daszę, kto ma zdolnosci, spoleczeństwu, w którem żyje, przydatne*. Tembardziej dziwic się̧ naleźy, że pewns część studentک́w ankietę p. K. przyjmowała drwinami $i$ lekceważeniem. 
na zęby, i że przecięciowo brakuje każdemu stadentowi $6-7$ zęb $\delta$ wl Jest to przyczynek wymowny do dziwnej n nas niedbalosci o najprostsze przepisy ochędostwa i bygieny potocznej. Ta mlodzież bezzębns jest w swoim rodzaju wyjątkowem zjawiskiem. Smntniejsze jeszcze rezultaty dala ankieta na punkcie chorób, niszezących dzielnośc $i$ energię zyciowş mlodzieży naszej w zarodku. Ankieta p. K. nie poprzestala na faktach, lecz sięgnęla do samych przyczyn. Istotnie, ważnem jest dla nas wiedziec, dlaczego połows blizku studentکw cierpi mniej więcej stale na ból glowy, dlaczego pulowa tylko nżywa systematycznie,

Jest to przyczynek wymowny do dziwnej n nas niedbałości o nsjprostsze przepisy ochęd6stwa i bygieny potocznej. Ta mlodzież bezzębna jest w swoim rodzaju wyjątkowem zjawiskiem. Smutniejsze jeszcze rezultaty dala ankieta na punkeie chorob, niszczących dzielnose $i$ energię zyciowş mlodzieży naszej w zarodku. Ankieta p. K. nie poprzestala na faktach, lecz sięgnęla do samych przyczyn. Istotnie, ważnem jest dla nas wiedziec, dlaczego połowa blizko studentów cierpi mniej więcej stale na ból glowy, dlaczego pulowa tylko nżywa systematycznie, w odstępach, przez hygienę przepisanych, kæ̨piell, dlaczego wreszcie

liczy mowea 12 prc., co wynosi 72.600. Wnioskodawca bierze zatem okrąglą cyfrę 5.50.000. Porl względem formalnym żąda mowca, aby wniosek jego odesłać do IVydziału krajowego, ktiory ma zwołać ankiete $\mathbf{z}$ czlonkiw komisji szkolnej i budzetowej, a uzyskawszy w ten sposób potrzebny materjał, stanąc $\mathrm{z}$ odpowiedniemi wnioskami przerl sejmem przy nạjbliższem jego zebraniu się.

Nad kwestyą miejsca, na którem pomnik ma stanąć, przeprowadzono obszerną dyskusyę, a ponieważ ankieta Rady miejshiej zamierza zaproponować pelnej Radzie w tym celu ogród miejski (Pojezuicki), zastanawiano się nad rozmaitymi punktami w tym ogrodzie, przyczem czlonkowie aukiety zasiadający w komitecie, mieli sposobność poznać zapatrywania członków komitetu. 
ta, zaproszons pr $\angle 0 z$ wydzial krajo:sy dla przestadyowania projektu ustawy bu.lowaiezoj dla wai 0 . raz pomniejszych miast i miasteczek Projokt ton juz od r. 1887 pokatujo po róznyeh konisyach, ankiotach, miniateryach $\mathbf{i}$ jakof $\mathbf{w}$ czyn zamioniony byó nie moze. Spodziewaé się nalezy, te wynikion obecnyeh obrad będzia narewzcio wprewadzenio * cayn powyzs?egr, projekta. - Otwarcio trzeciej stryi I nraów akademickjo' dla kobiet odbylo sie oneg-

Chodzi jeszcze o nazwe nadawaną dwudniowym rozprawom, których dziejami zająć się mamy. Petycya Klubu Konserwatywnego, uchwala sejmowa, a za nimi przeważna czẹść sprawozdań dziennikarskich używa wyrażenia ankieta, natomiast $\mathrm{w}$ petycyi Towarzystwa rolniczego, w referacie prof. Pilata dla Komisyi rolniczej, o którym jeszcze bẹdzic mowa, czytamy konferencya.

Pod ankieta rozumiemy zazwyczaj pisemne lub ustne zbieranie wiadomości o faktach, natomiast konferencya jest wymianą zdań i opinii, a wiẹc nie zbieranicm faktycznego materyalu, lecz dyskusyą nad nim, wyciaganiem $\mathrm{z}$ niego wniosków. Ze względu wiẹc na pożądaną

Komisya rolnicza; nastẹpnie należy zasiegnać opinii ludzi fachowych, znıwców i zwolać szerszą ankiete. Wniosek przez Sejm uchwalony brzmi doslownie jak nastẹpuje:

Wprawdzie w ankiecie zwolanej wskutek polecenia Sejmu dolno-austryackiego, a obradować mającej nad projektem zmiany prawa spadkowego i tworzenia zagród (geschlossene Höfe) bral udzial z ramienia tamtejszego Namiestnictwa referent dla spraw rolniczych (Landesculturreferent),

Początkiem dalszych prac na tym polu powinna być przedewszystkiem, o ile mi się zdaje, ankieta agrarna w možliwie największej ilości gmin typowych, przeprowadzona przez komisarzy miejscowych podobnie, jak to obecnie dzieje się w Czechach. Równieź bylaby pożądaną większa doza inicyatywy prywatnej na tem 
początkiem tain i podstawą każdej wažniejszej reformy ustawodawczej sa obrady grona ludzi fachowo wyksztalconych, lub w danym kierunku bezpośrednio zainteresowanych. Zazwyczaj komisya tego rodzaju zarządza zbadanie faktycznego stanu rzeczy (ankieta w ściślejszem tego slowa znaczeniu) zanim przedloży parlamentowi swe sprawozdanie, którego przeznaczeniem stanowić materyal dla dalszych obrad cial ustawodawczych.

tystyczne, ponieważ kierunek calej administracyi oraz polityki agrarnej, zaležy w znacznej mierze od - ile możności najdokladniejszej znajomości faktycznego stanu rzeczy; totez już z końcem ósmego dziesięciolecia przeprowadzono ankietę dzięki zarządzeniu Wys. Sejmu, obejmującą kraj caly, niemniej calość stosunków ekonomicznych.

Poniewaź coraz to jaśniej okazuje się potrzeba zmiany obecnego prawa spadkowego, przeto byloby pożądanem, gdyby przeprowadzono na obszarze calego kraju ankietę, opartą na zasięgnięciu opinii wladz politycznych, notaryuszów i sądów w sprawie zwyczajów spadkowych, podobnie jak to stalo się w ostatnich latach w Bawaryi i w Prusiech, a prócz tego należaloby oczywiście przeprowadzić ankietę $w$ gminach typowych na

Francuxi zaczynaja zastanawiad sie nad przyczynsmi wewnętrznego rozstroja swego społeczeŕatwa i cglądac się za srodkami naprawy. Zdaje się, to pierwsą zuebętę $w$ tym kierunk a dele arzgdzons przez p. Hurets $\mathrm{F} F \mathrm{~F}$ garze ankieta na temat: czy Francya rozwjo się lub upada? Wspominalismy jus swego czasu, te odpewiedxi wJpsdły bardzo ogólnikowo $i$ nntumistivesnin i a tola ankiate chohilg celn. 
kierunku dale urządzons przez p. Hureta w Figarze ankieta na temat: czy Francya rozwljs się lub upads? Wspominalismy jus șego czasu, te odpewiedxi wJpsdły bardzo ogúlnikowo i optymistycrnio, i o tylo ankieta chybila colu. Zachęcils ona jodnat ludzi powolanych do rozpatrzenia sie $\pi$ stosunkach fraju i Fydak poirrednio plegkny owoe $\nabla$ dweoh trigitrach

Budapeszt 15. lipca. Na ankiecie celnej oświadczy! Enyedy, iž jest zwolennikiem osobnej taryfy celnej, zastrzrga się jednak przeciwko temu, jakoby Węgry dopuścily się naruszenia traktatu wobec Austrji. Węgry kieruja

kraju ankietę, oparta na zasięgnięciu opinii wladz politycznych, notaryuszów i sądów w sprawie zwyczajów spadkowych, podobnie jak to stalo się w ostatnich latach w Bawaryi i w Prusiech, a prócz tego należaloby oczywiście przeprowadzić ankietę $w$ gminach typowych na wzór tej, którą w bieżącym roku zarządzila czeska rada kultury krajowej.

\section{Ankieta colna wo Węgrzech.}

Od dnia 14 lipea ankieta, która roz 
Zubranych powital p. przewodniczacy i w krítkich a jędrnych słowach przedstawił cel ankiety i upraszał, by zebrani obmyślili środki, zdazające do podniesienıa krajowego sadownictwa. Ażeby dostarczyć ankiecie podstawy. polecił Wydział krajowy, doc. K. Szulcowi z Dublan opracowanie materyału klimatologicznego w Galicyi, a prof. dr. St. Pawlikowi przedstawienie handlu owocami w Galicyi.

\section{Gdy Wydzial krajowy pracowal nad} ułożeniem ordynacyi wyborczej dla 30 miąst i zaprosił ankiete w tym celu, aby zasiągnąć także jej zdania, przedstawiona hyła tej ankiecie ordynacya wyboreza, w ktćrej mieściły się postanowienia, iż członkowie Wydziału powiatowego nie moga być wy-

i angielskich. Pisma angielskie twierdzą, iż jasnowłose córy Albionu dzierżą prym pod względem czystości, prasa zaś amerykańska kruszy kopje o przyznanie palmy pierwszeństwa amerykankom. Złośliwi yankeesi ogłosili ankietę międzynarodową, $\mathrm{z}$ której okazało się, iż amerykanka kąpie się trzy razy na miesiąc, francuzka tylko raz, a angielka... dwa razy do roku. Szczęśliwi amerykanie!...

\section{Chiromancja I Brunetiére. Wspól, racownik} Figara, Bernard, urządzil oryginalną ankiete : odniósl sie do szeregu najwybitniejszych ludzi we Francji z zapytaniem, jaki byl ich ideal w 20-ym roku tycia i czy go doścignęll? Wielu odpowiedzialo obszernie, inni lakonicznie. Do ostatnicb należy slynny estetyk 


\section{P. Dr. Dworski. JE. p. Jaworski} w swojem przemówieniu utrzymywal, że kwestya zmiany §. 102 ust. gm. z r. 1889 była przedmiotem obrad ankiety i że już ankieta uznala, iż innego wyjścia niema tylko albo wykluczyć człónków magistratu od udziału w Radach powiatowych względnie w Wydziałach powiatowych lub też zmienić \$.

Ankieta ogrodnicza $w$ Wydziale krajowym. W niedzielę, dnia 25 września odbyła się w I sali komisyjnej Wydziałn krajowego ankieta ogrodnicza, celem ombwienia jednolitej akcyi na polu całego sadownictwa krajowego. W ankiecie, która się odbyła pod przewodnictwem p. St.Brykczyńskiego wzięli udział: Prof. dr. E. Janczewski, prezes krakowskiego Towarzystwa ogrodniczego, jako delegat krak.

W innych paragrafach poczyniono nieznaczne mniej wažne zmiany stylistyczne.

Ankieta doszla do \&. 27, ma zatem jeszcze 29 paragrafów do przedyskutowania.

0 gedz. 5 popoludniu rozpoczęla ankieta dalsze obrady. 
Marszałek krajowy w najbližszym czasie zw0ła ankietę wszystkich prezesśw rad powiatowych, celem naradzenia się nad sytuacyą w kraju, której wyrazem jest zaprowadzenie sądów doraźnych i stanu wyjątkowego.

wewnętrzną dumę, powinny zupelnie wyplenić w nas to, co osłabia organizm spoleczny. Wspoldziałanie i wspjłpracownictwo w dzielach, najpilniejszych dla każdego, że wspomnieć tu oświatę ludu, udzial w kazdej zwołanej ankiecic czy komisyi, udzial ludzi przygotowanych, większem jest dobrodziejstwem, niz wysubtelnione dyskusye polityczne na temat zamorskich bohaterow.

Wezoraj odbyla ankieta trzecie $z$ rzędu posiedzenie, które trwalo od godz. 11 do $21 \%$ po poludniu. Dluższa dyskusję wywolal § 19 projektu ustawy, traktujacy o materjale i odleglosci budowli.

Przedsiębiorców - jakkolwiek zaproszonych było wielu - stawiło się zaledwio 20 , zo sfor robotniczych zaś wzięlo udzial 189 kobiet i 59 mężczyzn. Ankieta miala wiele klopotu, zanim się dowiedziala od każdej z uczestniczek cokolwiek o stosunkach pracowni, w których byly zatrudnione. To jednak, co za pomoca krzyżowego ognia pytań wydobyto, bylo wielce pouczającem. Wiadomo, że w wielu 
- Walka z grużlica na Weggrzech. W celu obmyślenis środkow, za pomoç̨ których możnaby walezyé przeciwko szerzenin sie grużlicy wśród bydłr, zwołał węgierski mivister rolnictwa w b. m. snkietę do Pesztu. Ankiets orzekls, że w obecnej chwili najwięcej odpowiednim Grodkiem jest oddzielenie zdrowych zwierzat od uznsnych $z 8$ chore na podstawie szczepienis tuberkuliny, które ma się wykonać na koszt pá́stwa. Uzuano aastępuie za bardzo pożądane z\&kazanie przywozu $z$ zagranicy zwierzęt reagujß̨-

kow, za pomoca których możnaby walezyé przeciwko szerzenin sie grużlicy wśrod bydłı, zwołal węgierski minister roluictwa w b. m. snkietę do Pesztu. Ankieta orzekls, że w obeenej chwili najwięcej odpowiednim środkiem jest oddzielenie zdrowych zwierzat od uznsnych zs chore na podstawie szczepienis tuberkuliny, które ma się wykonać na koszt państwa. Uzuano nastẹpuie za bardzo pożądane zakazanie przywozn $z$ zagranicy zwierzęt reagują-

asunięcia, \& w szozególnośor domagrajųoe się. aby ciala antonomiczno sprawş tą się zajęly, znalazly oddżięk w calej prasie, Jeduo z pism krakowskich doniosla juź nawet, iz marszaỉok krajowy takq ankietę zwolá́ po. stanowil - o czem nam atoli do tej chwili jeszcze nic autentyoznogo nie wiadomo Nadeszly dziś do Lwowa Wieniec ks.

Tutaj dopiero, na ankiecie dowiedziałem się, co jest celem nauki greckiego języka. Dowiedziałem się, $\dot{z}$ e celem tym jest oddzielenie mlodzieży od swiata i jego prozaicznych dążeń, utworzenie arystokracyi ducha. Z tem się nie zgadzam, bo nie to jest zadaniem 
Kancelista sądow y w Nadwórnoj Józef Kutschera przy przejśsin w stan spoczynkn otrzymal tytal i charakter oficyala II klagy.!

Ankieta w kwestyl żydow gallcyjskich zwolaną zostala do Wiednia przez tamtejoze Stowarzy-

Ćwiklińs ki wnosi :

"Ankieta wyraża potrzebę reformy w kierunku udoskonalenia i ulepszenia ob e c n e g o systemu szkól srednich."

Rotter wnosi przeciw temu:

"Ankieta oswiadcza się za taką reforma systemu szkół srednich, ażeby w miejsce dzisiejszych gimnazyów i szkół realnych, zaprowadzono jednolita

jednak uwagę, że gdyby znáczna część członków usunęla się od pracy w komisyi, byłoby to dla samej rzeczy szkodliwe. Ale zresztą, gdy Wydzial krajowy będzie miał konkretne wnioski dla Sejmu przygotować, to zwola znowu ankietę fachowa.

Wobec tego oswiadezenia marszalka, $\mathrm{Cz}$ a rtoryski cofa swój wriosek.

\section{Krajowa Ankieta \\ dla reformy szkót średmich.}

Ankieta szkolna zgromadziła się na pierwsze posiedzenie bardzo licznie. W obecności trzydziestu i kilku członków ankiety marszalek hr. B adeni o godzinie $11^{1 / 4}$ zagail narady, dziękując za tak liczne zebranie się. 
Zaznacza dalej, że sprawa ta obudziła ogólne zajęcie zarówno w zawodowych kolach jak i w szerokich kołach spolecznych. Sądzi, że ankieta nie powinna się krępować kwestya kompetencyi - bo nietylko kraj dąży do rozszerzenia kompetencyi swojej w sprawach szkolnych - ale też $i \mathrm{w}$ dzisiejszych granicach kompetencyi Sejm ma głos poważny

Ciągle stan wyjątkowy. - Ankieta szkolua. - Sekcya szkolna i opinia publiczna. - Zwycięztwo demokratów. - Zmartwychwstanie Życia. - Wystswa chryzantemów. - Ogrodnictwo.

winna się krępować kwestya kompetencyi - bo nietylko kraj dąży do rozszerzenia kompetencyi swojej w sprawach szkolnych - ale też $i \mathrm{w}$ dzisiejszych granicach kompetencyi Sejm ma głos poważny i wplywowy a glos tak poważnego ciała, jak ankieta, nie może pozostać bez wplywu na Sejm. Zwraca uwagę, że w krytyce obecnych szkól srednich instynktownie opinia publiczna wskazuje jako na głowną przyczynę vjemnych stron na tę okolicznosć,

Rozpisanoby najpierw konkurs na program ogólny, zgodny z planem naukowym. Dopiero po przyjęciu programu przez ad hoc zwolaną ankietę, rozpisanoby drugi konkurs na książki.

\footnotetext{
Ze strony Wydzialu krajowego wezmą ndzial w ankiecie, Dr Józef Wereszczyński szef departamenta oraz sekretarz Wydziałn kraj. Jan Autoniewicz, referent spraw szkolnych. Jako delegat Rady szkolnej krajowej weźmie udzial Dr Ludomir German, krajuwy inspektor szkol średnich.
} 
Ankieta jest to zebranie ludzi gruntownie z jakąś sprawą obeznanych, dla dania o niej opinii, wypracowania projektu jej zalatwienia. Tak n. p. zwoływał Wydział Krajowy ankiety złożone:

1) Wydawea Nene Freie Presse, p. Benedict, w ankiecie walutowej austryackiej 1892.; S'en xyr. Berichte str. 21. Prof. K. Menger w swem przemówieniu w ankiecie bardzo dobrze to skrytykowal.

Sie mogli wziąc் udzialu tylko poslowie hr. Dzieduszycki, Wachnianin i Zajączkowski; zresztą zgromadzili siẹ wszyscy w liczbie $\mathbf{3}$.

Ankiecie przewodniczyl Marszalek krajowy J. E. dr. Stanislaw br. Baleni, a tylko przez bardzo krótki czas zastçpywal go czlonek Wydzialu Krajowego dr. Józef Wereszezyiski.

W przeciwieństwie do nich skrajnem stanẹli ci, którzy byli ustateczuym powodem zwolania ankiety, a żądają zupelnẹ reformy systemu szkól srednich, jaki $\mathrm{w}$ Austryi istnieje. Jeżeli dohrze zrozumieliśmy dążność przeciwników, a szc'zególnie wuinskodawcy w Sejmie krajowym posla Rottera, to idzie właściwie o to, ażeby usmnąc gimuazya i sıkoly realne i jeź- 
dowała jakiś czas komisya w Akademii Umiejętności krakowskiej, a gdy wynik jej narad ogloszono, ocenil je zmarly wlaśnie radca dworu dr. Zygmunt Samolewicz calkiem spokojnic i przedmiotowo i wykazal niefortunnoṡe pomyslu. Prawie równocześnie radzono w komisyi lwowskiej o szkole jerlnolitej, o czem p. dyrektor Gerstmann na ankiecie mówil, i obmyslono jej program. Rzecz jednak poszla w zapomnienie, ale znowu tu i owdzie pojawiały się w pismach i dysputach niekorzystne krytyki dzisiejszego systemu, podnoszace rzekomo wyższe zalety naszych wlasnych polskich szkól dawniejszych.

I znowu słyszeliśmy na ankiceie jeszeze i takie zdanie, że szkola nasza nie daje broni do walki z życiem!

Ciekawy jesten, co może dać czlowiekowi silniejsza broń do tej walki, jak właśnie zaznajomienie go z temi idealami, które wskazują, jakinı czlowiek byé powinien.

Na liczne inne zarzuty, ezynione na ankiecie, przeciw dzisiejszym gimnazyom w dhuich, nicraz patetyeznych przemówieniach, wystarczy odpowiedzieć krótko, że tyczyły siẹ

Bogaty w liczbę, ale nie pewnej wartości arsenal grawaminów na dzisiejsze gimnazya i ustrój szkół średnich, konczył się projektem zaprowadzenia szkoły jednolitej t. j. jednej dla wszystkich: teologów, prawników, lekarzy, filozofów, techników i t. d. Z dyskusyi na ankiecie zostalo wszelako wrażenie, że żaden z czlonków jej, dążących do reforny, nie obnyślil bliżej, jakby w rzeczywistości szkoła jednolita mo- 
a na dalszym planie, ażebyśmy siẹ doczekali wszẹdzie i zdrowotnych stosuuków we wszystkich budynkach, i lekarzy, którzyby w kaźdej szkole nad stanem higienieznym pilnie ezuwali.

$\mathrm{Z}$ tą ostatnią uwagą przebieglis̉my prawie wszystko, co było na ankiecie poruszone i co do istoty rzeczy należy, o ile nam to bylo możebne bez stenografieznych sprawozdań, a tylko na podstawie dorywezo schwyconych notatek. 0 zupełne wyczerpniẹcie wszystkiegro, eo mówiono, naturalnie kusić sị̣ nie można, może nawet nie jedno nie calkiem do-

Ankieta znaczy doskownie dochodzenie, a w dalszem znaczeniu komisye wybraną celem dochodzenia lub uregulowania, omówienia i urządzenia czegoś, tak n. p. ankieta kolejowa radzi nad sprawami kolei, ankieta przemyskowa nad sprawami przemysłu.

P. Rotter wnosi uchwalenie potrzeby refurmy szkoł średnich, ktoraby na podstawie szkoly wspol. nej, czy tez wprowadzenia sto80wnej bifurkacyi w szkolach wyzszych, ułatwila abituryentom szkoly średniej wybór kiernnkn technicznego lab uniwersyteckiego. Wydział krajowy powolać ma w porozumienin z Radą szkolną krajową ankietę, w celu ustanowienia plann stosownej reformy szkol érednich. Wreszcie Sejm wyrazic ma potrzebę wydania nstawy pahstwowej, określajg̨cej 
P. R otter wnosi ponownie uchwalenie potrzeby reformy szkól średnich, któraby na podstawie $8 \mathrm{z} \mathrm{k} \mathrm{oly} \mathrm{ws} \mathrm{pó} \mathrm{I} \mathrm{nej} \mathrm{(jednolitej)} \mathrm{ułatwi-}$ la abituryentom wybór kierunku technicznego, lub uniwersyteckiego. Wydzial krajowy ma powolać ankietę $\mathbf{w}$ celu ustanowienia plann stosownej reformy szkól średnich. Wreszcje Sejm wyrazić ma potrzebę wydania ustawy pahstwowej, określającej zasady organizacyi gimnazyów.

względu na zbyt szozuplë ich pensyë, wetei jnarze od raza ourzymali 10 range, a nie juk obeonie 11 i aby pewna "atala ioh częśc byla mianowans do 9 rangi.

Ankicta $w$ gprawle \&Jd6 w. P. Stapinaki oswiadozs $\mathrm{w}$ N. fr. Pressie, te nie wetmie udzialn w an :iecie $\mathbf{w}$ sprawie źydów galicyjskioh, albowiem tego rodzaju przedsięwzięoie uws że z góry \&a bezcelowe.

eznyeh.

Ankieta ta zająć się ma omówieniem zasad organizacyi krajowego biura taryfo-

polem prywatnych poszakiwań i weszka w program prac reprezentacyi narodu, gdzie łatwiej i gruntowniej możo być zbadana. Na wniosek Rottel'a postanowił sejm galicyjski przoprowadzic ankietę $w$ sprawie refurmy i zaprosił do udziału w niej reprezent: ntow wszystkich instytucyi i stanów, któlych spostrzézenia i uwagi mogs byé poży teczno, a więc cakonków obu uniwersvtetow krajowveh. to- 


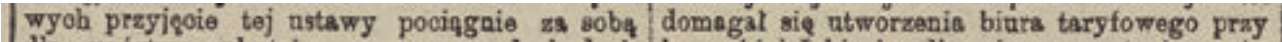
dle państws ubytek rooxny $w$ doohodaoh I wowakiej Izbio bandlowej $\mathrm{z}$ ewentualn sub. $1,400,000$ zlr.

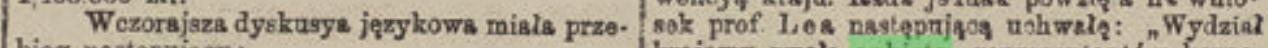
bieg nasteppujacy: Liberal Glo okner dlago rozwodzil się raoyj i Towarzystw ok onomioznyob krajowych

wiła sama pytanie doniosle: czy taki związek moze być uwazany za honorowy?

Ale niestety, ankieta moralnej strony szkoły galicyjskiej nio dotykała.

Cho.

\section{(Dokohczenie).}

Maurycy Pujo jest współpracownikiem pisma $L$ 'Art et la Vie; rozumio on krytyke na swój spos6b, jest to dla niego rodz $j$ ankiety 0 ideach moralnych naszego czssu; ankietę ową czyni Pujo, aby dojść przez szoreg liquidations do wlasnej liberation. W chaosio dążeń wybiora on najbardziej znaczące, aby osiągnąc wyrobienio ezłowiecze. Krytyks więc u M.

i jestem przekoneny, to tylko podobne środki pomoglyby ne dkumę moralnq; latwiej bowiem jest zapobiedz zaratenia, jak wyleozyć zarażo. nego. Mieczystaw Konopacki.

\section{Ankieta szkolna.}

Wezoraj o godz. 11 przed poludniem rozpoczęly się $\mathbf{g}$ gmaohu Wydzialu krajowego obrady ankiety szłolnej, na którq̨ Wydz:al kra. jowy zaprosil najwybitniejszyoh przedsta wioieli 
$\overline{6}$

KU:

KURJER PORANNY. - Warszawa, 9 grudnia 1898 r, piątek platufo nießê pomoc polołnicom, 59 lat wieku - wiẹc ma widoki zoacz- tywa z wystawieniem N. Saka - Ankiets micjska lwowska w nego jeszezo pongovebla obecuie o- w paszce, na iotebeje Arey

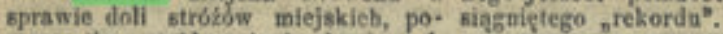
stanowilh zrewidowá micszkasik siró. Lów w ealym Lwowie. Rewizja od. bedzie się dzielnieamt $\mathbf{z}$ udzialem ko.

misarza magistratu 1 znawców.

Kalendarzyk tygodniowy Piatek. Leekadin i wal. ezci Niepokalanego Serca $\mathrm{A}$

Panny z od́spiewaniem litaj ceşą.

- Jutro o g. 7 r. w kosels Jacka, odprawiona będzie

strzeżenia i uwagi mog̨z byé pożyteczne, a więc członków obu uniwersytet $\delta$ w krajowych. towarzystw : politechnicznego i lekarskiogo, "związku rodzicislskiego", i wielkg̨ liczbę nauczycieli. Ankieta ma stwierdzic, jakie jest zadanio i cel szkoły średniej, czy colowi temu odpowiadają gimnazya, oraz szkoły realne, i które z tych zakładów większy przynoszą nońrtalt? Dalai iakia hrsai ndezuwaia nez.

stw0? Nareszcie, wzywa ankieta do podawania projektów reformy i stawia pomiędzy innemi pytanie, w jaki sposób naleźaloby uzupełnic plan nauk i sposób wychowania, aby szkoly realue i gimnazyalne czyniły zadosic potrzebom społeczeństwa.

Wynik poszukiwan moze byc tem aoaatniejszy, ż $\theta$ ankieta obraca się nie w ramach tooretyeznych, lecz staje na gruncie ezysto praktycznym, na gruncie potrzeb spoleczeństwa. Poznawszy to potrzeby, będzie można zastosować się do nich, przy wypracowaniu nowego systemu nauki. 
Nie czekając na materyał obu ankiet wspomnianych, galicyjskiej i wiedeńskiej, chcę tutaj przedstawic w zwięzłym zarysie położenie ludności żdowskiej w Galicyi, na podstawie materyału, jakim dziś mogę rozporządzac, i dostarczyé w ten sposób objektywnej podstawy do sądu o rozruchach i ich przyczynie, a następnie do sądu o przyszlym

ankra

. Ankier, Ankra, takìe kotew albo zwora, jest to żelazo skứżce do związania ze sobą części budynku n. p. belki z murem albo ściany ze ścianą. Zob. Zegar.

anteridium

reczek; z tych każda daje początek jednej parze plemników. Komórkę tak̨̧ zwiemy anteridium czyli plodnikiem. U innych gatunk6w Oedogonium nić, produkująca jajniki, nigdy nie wydaje plemników; te ostatnie wytwarzane bywaja przez nici tylko do tego celu przeznaczone. Widocznie, że już i tutaj mamy do czynienia $\mathrm{z}$ rozdziałem funkcyj pleiowych, charakterystycznym dla roslin

antipolski

Fiasko hakatystów Nie wszyscy Niemey zarażeni 8 ą chorobą antipolską, jak tego dowudzi zwo. rane przez hakatystów zebranie w mieście Kowalewie, w Prusach Zachodnich. Na zebraniu tem przemawial platny agitator dr. Bovenschen, aby zalo- 
arytmograf

\section{Rozwiazanie arytmografu urvieszczonego w N-rze ji.}
1) Kle.jnot
2) Ignomen
3) Bajgkit
4) Afing:r
5) Jjalbergia

Astor

król botelowych przedsiębiorstw, jak Flagler, król parceli budowlanych, jak Astor, król wagonów, jak Pullman, król prasy, jak Pulitzer, i wielu, wielu innych.

\#B

bakterjologiczny

re usiluje uosobnić za pomocą osobliwych figur eyrklowych, nadających artykułowi pozór rozprawy bakterjologicznej, autor usiłuje dać dokładny obraz widoków zamążpójścia kobiet wogóle, w szezególe zaś w stosunku do wiekn.

bez żółci

kol. Kurkiewicz. W przemowie swej zastrzegał się przeciw temu, aby właściciele aptek nie užyli swej przewagi wtedy, gdy opinie współpracowników będa przeciwne i aby ta dyskusya toczyła się na prawach równych bez obawy, ze który za śmielsze słowo može ucierpiec. W dalszym ciagn kol. M. Kulak przemawiał, aby kotedzy współpracownicy dyskutowali leez żółci, spokojnie, gdyż właścicielom aptek zarówno jak i współpracownikom jednako zaležeć powinno na utrwaleniu stanowiska $\mathrm{i}$ bytu zawodu. 
bifurkacya

Mamy odpowiedzieć na pytanie, czy dążyé do reformy szkók srednich - a nie wątpię, że wiclki większosć za reformą się oświadczy. Potem przychodzi pytanie o zupelnie jednolitą szkołę średnią oczywiście bez obowiązkowcj greki. Trzeba, żeby ankieta $w$ tej sprawie wypowiedziała calkiem stanowczo swoje zdanie. Gdyby to miało upaśc - przychodzi wniosek Reya o jednolitą szkołę $\mathrm{z}$ bifurkacyą i z szerszem uprawieniem co do uczęszczania jej maturzystów do wszelkich wyższych ząkładów nauko-

prąd materyalistyezny wymagałby raczéj wzmocnienia pierwiastku idealnego w kształcenin kultn ideałów, których źródło wieczuie tryskające i ożyweze świat starożytny pozostawił w spuściźnie całéj ludzkości.

Jak zawsze w takich razach bywa, skoúczyło się na uchwale pośrednią drogę zalecającéj. Ankieta uchwaliła wniosek hr. Reya, według którego należałoby zaprowadzić jednolitą szkołę średnią z bifurkacyą $^{n}$ (sic) w klasach wyższych, z których jeden oddział niałby odróżniać się od drugiego nauką helenizmu z nadobowiązkową nauką języka greckiego, a oba oddziały kwalifikowałyby potém zarówno do

biuro taryfowe

\begin{tabular}{|c|c|}
\hline 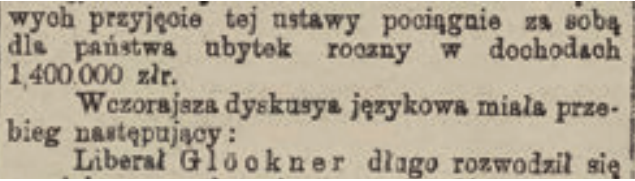 & 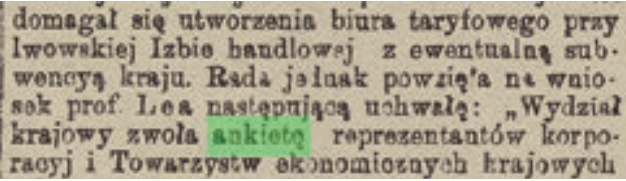 \\
\hline
\end{tabular}

biuro telegraficzne

Stary renomowany hotel familiny nowourzłdzony. 200 polkojów golicinnyes od 1 fiorena poczawszy, lącznie $z$ usługą i swiattem. $\mathrm{C}$. K. hiuro tolegraficzne i telefonow nam.ejs n. Eorzystne polozonie dla zwiedzających vystawe fulleuszow?. Ceny niepodwyiszone. Jworce kolejowe i przystanki parowców w najbliz. szem sasiedztwie. Tramwaje $\mathbf{i}$ omnibusy hotelowe we ws ystkich kierukkach. Znako. mita restauracja, winda osobowa. F. M. MAYER W'asciciel. 
bladaczka

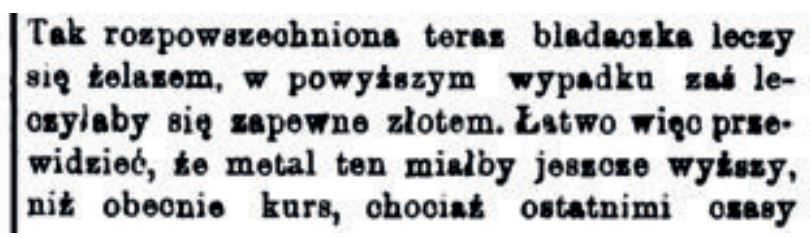

blankiet

Pani Walerya odzyskala glos, widząo to prezes ohoial naded oalomn zdarzenin oharkktor żarta.

- Czy mój mąz jest ozlowiekiem smiesznym? ozy mu nio wolno trzymad administracji? pisad́ na blankietach ? W Niemozech...

Prezes uchwycil iq za rękę i przerwal.

\section{mienie o tem, do kancelarji komisa-} rza generalnego, nie później jak do 12 grudnia r. b. Zawiadomienia powyższe naleźy przysyłać $\mathbf{w} 2$ egzemplarzach, na blankietach wysyłanych bezpłatnie przez kancelarje powyższą a mieszczących w sobie pytania, na które wystawca musi dać odpowiedź.

Warunki przedsiębiorstwa przejrzane byé
mogą w godzinach urzedowych w wymienionem
c. k. Starostwie, gdzie także w wyż o-
znaczonym dniu uajpóżniej do godz. 12 w po-
kudnie wnoszone byé mają oferty, sporządzone
na blankietach urzędowych, których Starostwo
bezplatnie udzieli, a zaopatrzone marką stem-
plową na 50 ct. i we wadyum wynosz̨ce $5 \%$
kwoty fiskalnej, z wyrażeniem opustu cen
jednostkowych nie tylko eyframi ale i literami. 
blankiet firmowy

Simutnym i pozałowania goduym faktem jest tèz to, że bardzo dużo takich mamy, co nie cheq szanować naszych pięknych nazwisk polskich, lecz je przekręcaja i kaleczą. Tak zdarzyło mi się juž up. na rachunkach, blankietach firmowych i szyldach spotykać nazwiska tak pokaleczone: Bieschky, Gursky, Nawrotzky, Woyezychowski, Schymansky itd.

blankiet wekslowy

Przedewszystkiem, co do weksli przypominamy, że z zaprowadzenia znaczków stemplowych kóronowych na blankietach wekslowych, wcale nie wynika obowiązek wystawiania weksli na walute koronową. Weksel bez wzglęảu na to, jaki jest na nim stempel, może być wystawiony w każdej legalnej walucie.

W roku 1897 to jest od 1 styeznia do 31 grudnia obrót tytoniowy wynosił $39075 \mathrm{z}$. 22 et., zysk $z$ drobnej sprzedaży wynosił $w$ tym ezasie 253 zł. 64 et., zaś obrót w stemplach, listach przewozowych i blankietach wekslowych wynosił 6512 zl. 91 et, od sprzedaży tych znaczków wartościowych będzie pobierał składownik pół procent.

bydło opasowe

- Ankieta w sprawie założenia rzeźni i targo wicy na bydlo opasowe w Podgórzu odbyla się w ostatnią érodę w podgơrskim Magistracie przy udziale posła Hermana Czecza, burmistrza p. Garbaczyńskie go, reprezentantów gminy oraz grona osób facliowych. 
\#C

cena jednostkowa

Warunki przedsiębiorstwa przejrzane być moga w godzinach urzędowych w wymienionem c. k. Starostwie, gdzie także w wyż 0znaczonym dniu rajpóźniej do godz. $12 \mathrm{w}$ poludnie wnoszone byé mają oferty, sporzq̨dzone na blankietach urzędowych, których Starostwo bezplatnie udzieli, a zaopatrzone marką stemplową na 50 et. i we wadyum wynoszące $5 \%$ kwoty fiskalnej, z wyrażeniem opustu cen jednostkowych nie tylko eyframi alo i literami.

centralny zakład ogrzewający

na listowrm papierze; pokoj w wfqq znie dịa pań przezusozany, lavotor itd. N Najprzyjerg: niej dziala na proybywajacego do hotelu roz:k08zne cieplo rozlewrjace si z po wazystkioh kątach hotelowyoh, a wysylane z centralneg ) zalkladu ogrzewajacego. Cieplo to odrazin ozy. ni hotel kałdemu milom, kto znqzony i wys ozerpany podrók przybywa. W eleganokiej jadsini, jedjnej $\mathbf{w} 8$ woim rodzaju, bc odw $\theta$

chromolitograficznie

WSZYSTKIE DZIAEY BOGATO

ILLUSTROWANE.

Premje gratisowe:

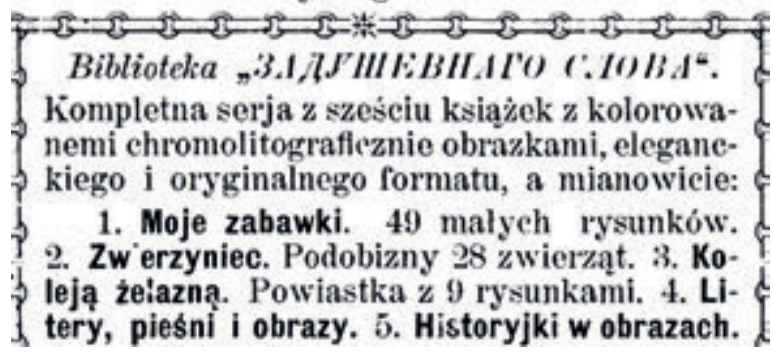


ciemno-różowy

\section{(Do artykutu 6 umow y).}

$\S 2$. Listy przewozowe międzynarodowe wygotowywać należy na blankietach, których wzór podaje załạcza $\left.2^{1}\right)$. Blankiety te powinny byé wydrukowane do posylek zwyczajnych na białym, do pospiesznych na eiemno-róz̀owym papierze, a zgodnośc ich $\mathrm{z}$ dotyeząeymi przepisami umowy niniejszej potwierdzona być ma wyciśnięciem

co gorsza

xure wlasnie studyowar.

wiód " ${ }^{n}$ Familijny wieczorek" kompletnie nie poności narzeczonego Loli, któremu ohoiano pokazad, te i dwór Jarowinieoki ma swojego poetę. Towerzystwo bylo w kwaśnym humorze, jedna tylko Lola nie wiedzikla dobrze 0 co chodzi. XT: $\mathbf{r}$

człowiek dobrej woli

stów ze swej strony również dołożyé cegielkię, które wrięte razem przy szezerych ehęciach ludzi dobrej woli, być może wkrótce, utworza fundament nowego gmachu jednej z najsympatyezniejszych instytueyj naszego miasta. Vivat sequens!

\section{czynić zadość czemuś}

stwo? Nareszcie, wzywa ankieta do podawania projektów reformy i stawia pomiędzy innemi pytanie, w jaki sposób naleźałoby uzupełnic plan nauk i sposób wychowania, aby szkoly realne i gimnazyalne czynily zadose potrzebom społeczeństwa. 
\#D

dawać początek czemuś

zaś różnica między niemi a zoosporami polega na tem, że, będąc odosobnionemi, nigdy nie daja początku nowym niciom Oedogonium, lecz powoli giną. Pochodzenie tych elementów męskich czyli plemników nie $\mathrm{u}$ wszystkich przedstawicieli rodzaju bywa jednakie. U jednych taż sama nić, ktorej komórki utworzyly jajniki, wydaje w pewnych miejscach rząd krótkich komó-

dentystyka

III. Nanka lekarska: 1) Anatomia. 2) F'izyolugia. 3) Psycho-fizyologia. 4) Patologia : a) ogólna, b) szczegółowa. 5) Środki farmaceutyczne. 6) Seroterapia i serodiagnostyka, organoterapia. 7) Narzędzia chirurgiczne (ginekologia, oknlistyka, laryngologia, dentystyka etc.). 8) Elektroterapia i elektrodiagnoza (Roentgen).

dezynfekcyjny

p. Józefa Polkowskiego chemika, wraściciela kamery dezynfekcyjnej. Zmarły $n$ byl synem przed niedawnym czasem $t$ zmarłego malarza-jubilata, b, nauczy- 1 ciela gimnazjum s. p. Józefa Polkow- k skiego. Na trumnie zlożono 2 wieńce, $\mathrm{z}$ tych jeden od rodziny, drugi z na- $\mathrm{c}$ pisem: .Swemu koledze-chor .Brat- $v$ 
diagnostyka

zainteresowanie wzbudzi miedzy innemí także przedstawienie dalekowidza (teletroskopu) przez wynalazeę samego p. Jana Szczepani$\mathrm{ka}$, oraz kilka wykładów o zastosowaniu promieni Roentgena do diagnostyki z przedstawieniem przyrządu samego.

$\mathrm{Na}$ dnie 25 do 27 czerwea zapowiedzianą została rzadka uroczystość pólwiekowego jubileuszu Towarzystwa przemyslo-

drogą czegoś

jeszcze, nieprzechodząo w stan spoczynku, jaki zwykle nastẹpuje po każdym podziale komórki. Dopiero produkty ostatniego podzialu, t. zw. spermatydy, przetwarzajæ się we wlasoiwe plemniki droga zmian, zachodzących w samem ich ciele.

drogman

0 istnieniu tego pomnika wiedza chyba tylko parafianio kościoła, dojrzeć go bowiem z ulicy niepodobna, przewodnicy zaś hotelowi i drogmani nic o nim nie wiedza.

Kilkakrotnie bywalem w Smirnie i nie podejrzewalem nawet istnienia pamiątki, jaka jest mauzoleum, poświęcone pamięci rodaka. Gdyby nie

\section{dworzec kolejowy}

Stary renomowany hotel familisy nowourzadzony, 200 pokojów gobinnyox od I florena poczawszy, lęcznie $z$ ushuga i swiattem. C. K. biuro telegraficzne i telefonów na mejs n. Korzystne polozenio dla zwiedzających wystawę jultieu. szow?. Ceny niepodwyźszone. sworce koiejowe i przystanki parowców w najbliz. szem sasiedztwie. Tramwaje $\mathbf{f}$ omnibusy hotelowe we ws ystkich kiernnkach. Znakomita restauraja, winda osobowa. F, M. MAYER Whasciciol.

\section{口LA ZAKKAQÓW KĄPELOWYCH i QLA LETMHKÓW,}

Lawn-Tenn s, Krokiety, Badminton, Cricket, Boccig, Gra to Zabs, Rakioty, Wolanty,_Kregle 
dzieciński

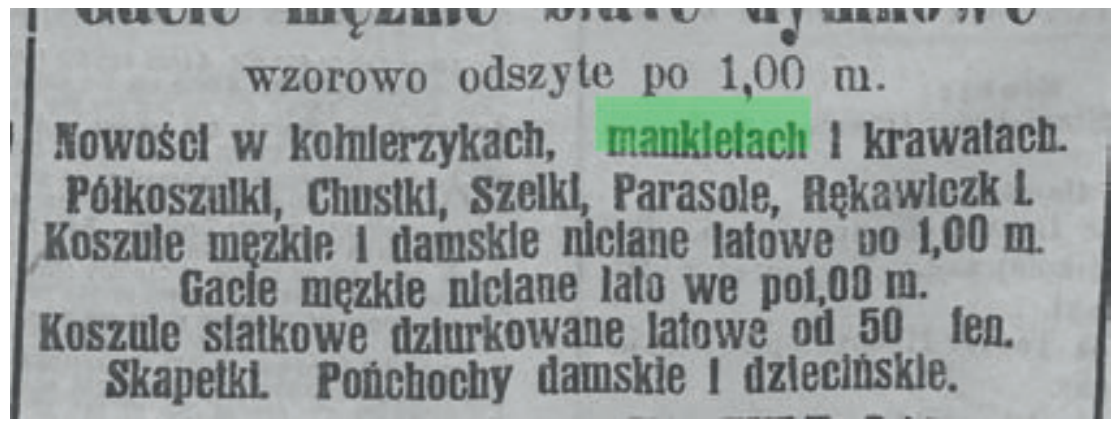

\#E

ektodermiczny

Fig. 5. Samiec w chwili wydalenis nasienia przez rozpad ektodermiczny ckt; $s p$ plemniki, $m$ mięśnie.

elektrodiagnoza

III. Nanka lekarska: 1) Anatomia. 2) Fizyologia. 3) Psycho-fizyologia. 4) Patologia : a) ogólna, b) szczegółowa. 5) Środki farmaceutyczne. 6) Seroterapia i serodiagnostyka, organoterapia. 7) Narzędzia chirurgiczne (ginekologia, oknlistyka, laryngologia, dentystyka etc.). 8) Elektroterapia i elektrodiagnoza (Roentgen).

elektro-techniczny

8. S̄pólkì eksploatujące wagony

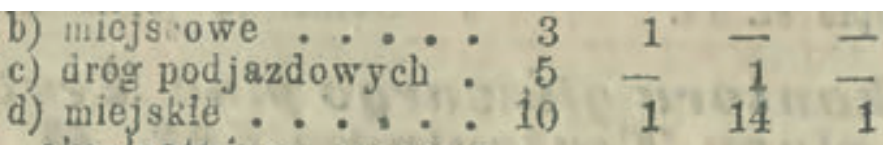
specjalno, ekwip. miej. i t. d. .

9. Sp. hotelowe, kapiol., pralnie : 6

0 . ekspl., domy, składy, elewat. 15

1. Tow. aseniz., wodoc. i gazowe. 15

2. $n$ elektro-techniczne ... 11

3. Sp. robót publ, (studnie artez., 
elektroterapia

6) Dezinfekcya. 7) Gimnastyka lecznicza i t. d. 8) Odzienie.

III. Nanka lekarska: 1) Anatomia. 2) Fizyologia. 3) Psycho-fizyologia. 4) Patologia : a) ogólna, b) szczegółowa. 5) Środki farmaceutyczne. 6) Seroterapia i serodiagnostyka, organoterapia. 7) Narzędzia chirurgiczne (ginekologia, oknlistyka, laryngologia, dentystyks etc.). 8) Elektroterapia i elektrodiagnoza (Roentgen).

IV. Środki spożywcze i odżywcze. 1) Przetwory mięsne. 2) Przetwory mleczne. 3) Przetwory mączne. 4) Konserwy. 5) Napoje alkoholiczne. 6) Napoje bez

en profil

En profil (mów: an profil) znaczy: $\mathrm{z}$ boku $-\mathrm{t}$. j. patrząc $\mathrm{z}$ boku n. p. wizerunek czyjś "en profil " oddaje tylko tę część twarzy, którą widzieć można $\mathrm{z}$ boku.

\#F

familijny wieczorek

xtora wlaśnie studyowar.

wiódl ${ }^{n}$ Fię, \& co gorsza fissko nastapilo w nósoi narzeczonego Loli, któremu ohoiano po* karad, te i dwór Jarowinieoki ma swojego poөtę. Towarzystwo bylo w kwaśnym humorze, jedna tylko Lola nie wiedziala dobrze o co ohodzi. XT: 
farbiarsko-mydlarski

- Panów Przedsiębiorców budowlanych o zajęcie przy odbiorze wapna, eegły i innych materjakow do budowy potrz ${ }^{\circ}$ bnych. Oferty laskawe proszę złożyć Senatorska Nr. 29, sklep farbiarsko-mydlarski dla „Bonasventury ${ }^{\prime}$. 3404 Osoba pojedynicza lat średnich z kaucją, poszukuje filji pieczywa, obeznana z tym fachem odpowiednio. Wiadomość ulica Podwal Nr. 40, filja. $3: 8$ )

farmaceutyczny

organ Galicyjskieso Tow. farmacentycznego „Jnitas" w Krakowie.

$\rightarrow++$ Wychodzi każdego $15^{\circ}$ w miesiącu. ...

Cztonkowie Tow. farmaceutyczego „Unitas* otrzymują Kronike farmacentyeznq bezpłatnie.

Adresı Galicyjskie Tow. farmaceutyezne „Unitas" w Krakowie „Redakeya”.

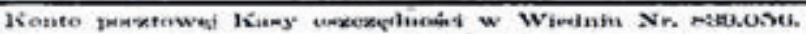

fiasco

Fiasco (czytaj fiasko), $\mathrm{z}$ włoskiego, znaczy zupelne niepowodzenie, spelznięcie powziętego zamiaru na niczem, poraźka.

fiasko

acyi, ludność uspokoiła się, a nawet zawodowi krzykacze spuścili z tonu. Nawet wielki meeting, zorganizowany przez Deroulède'a w maneżu przy Avenue de la grande armée, w gruncie rzeczy zrobil fiasko, a manifestacyjne zebrania senatorów i deputowanych, nieprzychylnych rewizyi, wprost wzbudzaja politowanie: uczestniczyło w nich po jakie dwadzieścia nsób. 
xtora wlaśnie studyowar.

Familijny wieczorek" kompletnie nie powiódl się, a co gorsza fissko nastąpilo w obeonośoi narzeczonego Loli, któremu ohoiano pokazad, te i dwór Jarowinieoki ma swojego poete. Towarzystwo bylo w kwaśnym humorze, jedna tylko Lola nie wiedziala dobrze o co chodzi.

XT: _ ...:

du. W lutym bo $i$ lat innych przypominamy sobio tu ciepla, wobec których letni paltot nawet wydawal się zbytecznym; żeby jednak i w styczniu na letnim tylko módz poprzestawaé, tego nie pamiętają i zasiedziali tu obywatele. Zupelnege fiaska doznaly wobec tego tutejsze ślizgawki, które nie oglądały do tej pcry cienia lodu i nie będą go już chyba oglądnc. To też zapaleni Kýzwiarze tutejsi odbywają za lodem wycieczki w góry, na zd̉radliwo jeziora

Flagler

król hotelowych przedsiębiorstw, jak Flagler, król parceli budowlanych, jak Astor, król wagonów, jak Pullman, król prasy, jak Pulitzer, i wielu, wielu innych.

formalny

Kwestye powyższe przedstawił prof. Janczewski w formalnych wnioskach, ktoce zostały przez ankietę przyjęte jednomyślnie. Przem6wienie dr. Szyszyłowicza spowodowało ostateczne zalatwier: sprawy zajmującej ankietę - a mianowicie przez wybór komisyi z groza znanych pomolog $6 \mathrm{w}$ dla każdej strefy klimatycznej, celem doboru 0 wocó w najlepiej odpowiadających warunkom naszego kraju. W skład takich komisyj ve- 


\section{\#G}

giełda pieniężna

sprawiedliwości przeprowadzoua begdzie ankieta dla reformy ustawodastwa akcyjnego. Odpowiodnie kwestyonaryusze, które majos byé w przecig̨gu dwóch miesięcy zwró́cone ministeryum, zostały juž przeslane zurıgrom gield pieniegznych $i$ towaro-

\section{gimnastyka lecznicza}

6) Dezinfekeya. 7) Gimnastyka lecznicza i t. d. 8) Odzienie.

III. Nanka lekarska: 1) Anatomia. 2) Fizyologia. 3) Psycho-fizyologia. 4) Patologia : a) ogólna, b) szczegółowa. 5) Środki farmaceutyczne. 6) Seroterapia i serodiagnostyka, organoterapia. 7) Narzędzia chirurgiczne (ginekologia, oknlistyka, laryngologia, dentystyks etc.). 8) Elektroterapia i elektrodiagnoza (Roentgen).

IV. Środki spożywcze i odżywcze. 1) Przetwory mięsne. 2) Przetwory mleczne. 3) Przetwory mączne. 4) Konserwy. 5) Napoje alkoholiczne. 6) Napoje bez

\section{gimnazyalny}

Cheąe wstạpić do apteki naleźy przedewszystkiem wykazać się șwiadeetwem $z$ ukoniczonej $\mathrm{z}$ dobrym postępem 6 klasy gimnazyalnej i potrzeba mieć jaki taki majạteczek. Praktyka w aptece trwa przez 3 lata, w którym to czasie otrzymuje uczeń wikt i pomieszkanie, lub odpowiednie za to wynagrodzenie. Po skończonej 3-letniej praktyce składa on egzamin z chemii, nauk przyrodniczych, towaroznawstwa, znajomości receptury i laboratoryum, poczem zostaje asystentem (podaptekarzem). Na mocy tego egzaminu ma asystent prawo do jednorocznej stužby wojskowej i zobowiązany jest zapisaé się z nadchodzącym pażdziernikiem na 2-letni kurs farmacyi na wszechnicy, jeżeli ehce wogóle zostać kiedys samoistnym aptekarzem, lub tylko zarzạdeą albo dzierżaweą apteki. 
gospodarstwo rolne

Uregulowanie sadownictwa. Piszę nam ze Lwowa: Wystawa ogrodniczo-pszczelnicza poruszyła waźng̨ kwestye uregulowania sadownictwa w Galicyi, które dziš w upadku staćby się mogło znakomitą pomocs dla gospodarstw rolnych. W tym celn zgromadzila się ankieta, zwolana staraniem prof. J. Szyszylowicza.

\section{\#H}

hausknecht

Bylo to 0 godzinie dwunastej w nocy.

W hotelu pod ,zlotym lwem" w X. panowala cisza grobowa. Tylko na ganku slyszano jeszcze leniwe stąpanie. Był to sluga hotelowy czyli jak go najnowszą polszczyzną nazywają hausknecht, Stach, który chodzil ode drzwi do drzwi, aby zbierać buty i buciki, wyczekujące czyszezącej jego ręki.

Do polowy spelnil juź missyę swoją i nic nadzwyczajnego w tym czasie się nie wydarzyło.

hegar

Trituratio hydrarizyri eum Innolino an part. aequales, kilo 3 zkr. 90 et.

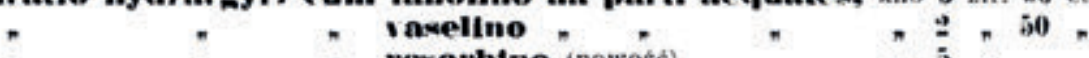

- $n$ remorbine (nowosé)

Utrzymuje na składzie ważniejsze materyały apteezne, hegary blaszane i szklane, szkło apteczne, termometry maksymalne, kąpielowe i ścienne, flaszeczki-kroplomierze, zakraplacze, p̧̧zelki, pęzle do gardła, worki na lód, wstrzykawki szklane eałe, lub w oprawach eynowych albo kauezukowych, alkoholometry, lampki spirytusowe, knlbki szklane $i$ wiele innych utensyliów zawartych w cennlku. 
hemoroidalny

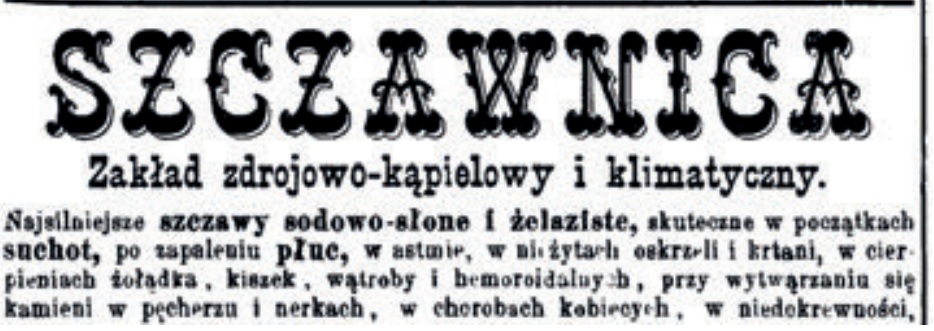

historyjka w obrazach

WSZYSTKIB DZIAEY BOGATO

ILLUSTROWANE.

Premje gratisowe:

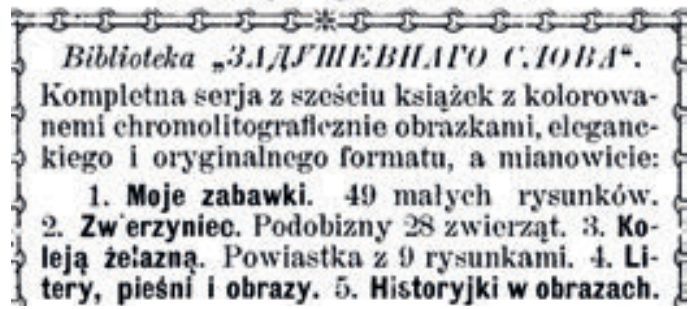

hotelier

pie na jedn̨ zloţ̨ sztukę. W dniu, w którym się mlodzieniec ulotnil z hotelu na zawsze, kazal gobie w dodatku hotelierowi zmienió falszywa sztukę na drobne.

hotelowy

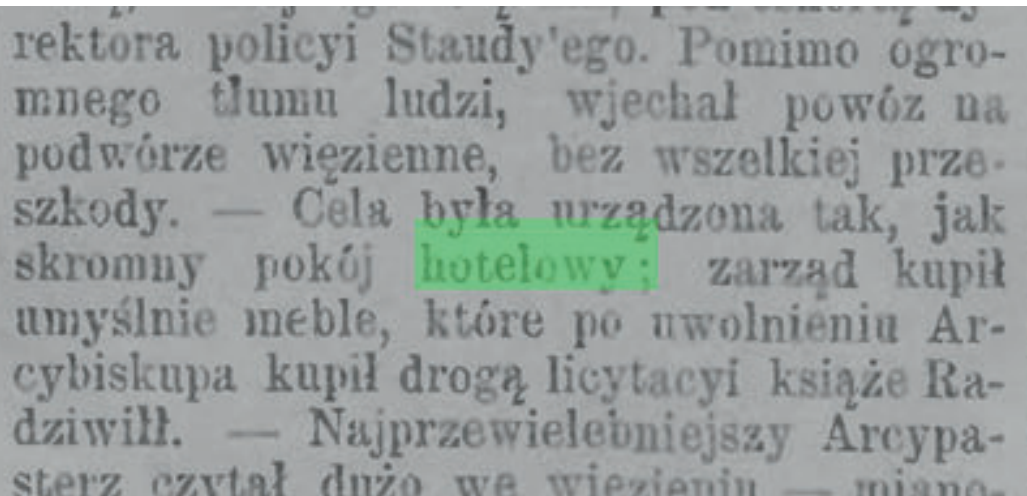


ge do Paryża. Zawiadomienie glosilo, iz̀ rabusiem byl czlowiek mlody, elegancko ubrany, mówiący dobrze po frapcusku, te wreszcie napastowany ukasil go $\mathrm{w}$ ręke $\mathrm{w}$ czasie walki, rtóra się wywiązala w pokoju hotelowym. W poniedzialor, o godzinie $9^{1 / 2}$ z rana, po przyjściu pociagu pospieaznego z Nizzy, z wagonu wysiadl podróźny, którego powierzchowność zgadzala się z nadeslanym rysopisem. Inspektor

trag) kodeksú terezyañskiego (III. 19 n. 100.). Przeciwnie SCHEY str. 397 twierdzi, że przy przyjęciu podróżnego przychodzi do skutku rzeczywisty, a więc nie domniemany kontrakt składu. Gdyby tak bỵło, przepis §. 970 . u. c. byłby najzupełniej zbytecznym.

${ }^{7)}$ Rozwinięte życie hotelowe daje tysiączne pod tym względem wskazówki. Rzeczy więc muszą byé poczytane za "oddane", jeśli - jak to się dzieje - fnnkcyonaryusz gospodarza już na dworcu kolejowym odbiera od podróźnego pakunek a nawel jeśli w celu odebrania rzeczy od kolei, odbiera kwitek

- Chocby najpilniej mi bylo. . Bardzo mnie to interesuje.

Szli trotuarem powoli, noga za nogă, i Iiirycz zacząl swoje opowiadanie:

- Muszę panu naprzód jeden szezegól potrzebny powiedziec. Moj koncert chcialem zaprezentowac Niemiaszkom sam, osobiście. Licho nadało, ze mi akurat pierwszego dnia pobytu w Berlinie, w kurytarzu hotelowym zawiało ramię; głupstwo, ale zawsze dolegliwośc, i grać nie sposobb. Kto wie, czy nie stało się to za sprawą Opatrzności, czuwającej widocznie nade mną w ostatnich czasach laskawiej nieco, bo dali mi fortepianistę Niemca, takiego szelmę artysı̨̨, że jak mi mój koncert wyrzng̨l, aż sam się ździwiłem, iż to takie piękne miejscami. Na razie 
0 istnieniu tego pomnika wiedzą chyba tylko parafianio kościoła, dojrzeć go bowiem z ulicy niepodobna, przewodnicy zaś hotelowi i drogmani nic o nim nie wiedza.

Kilkakrotnie bywałem w Smirnie i nie podejrzewalem nawet istnienia pamiątki, jaką jest mauzoleum, poświęcone pamięci rodaka. Gdyby nie

Pospolity trum zlodziejski npracuje" wedle jednego i tego samego szablonu, przy czem nie rzadko miewajq̨ do pomocy i вpólki kobiety nderzającej piękności. Osobną kategoryę hotelowych zlodziei, stanowią tacy, co na zasadzie falszywych swiadectw dostają się między sluzbę hotelow̨̧ jako czý́ciciele lamp, stajenni itd. Tego rodzoju specyaliści, miewają zozwyczaj wapólników w mieście i wyrzuçją im przez okno wazystko to, co u pasażerów pokradą̧. Sku-

Rzecz cała wyjaśniła się w ten sposób, że przemyślny kelner wyprzątnąć kazał dla nadliczbowych gości lazienkę hotelową, ustawił łóżka w miejsce wanien, ale zaponınial odjąć sznury otwierające natryski. Pani młoda pociągnęla za sznur, sprowadzający silną tuszę, pan mlody zaś odsunął nad sobą sito deszczowe i tak obojgu wydarzyla się pamiętna awantura, której nie kaźda mloda para podróżująca zażyje.

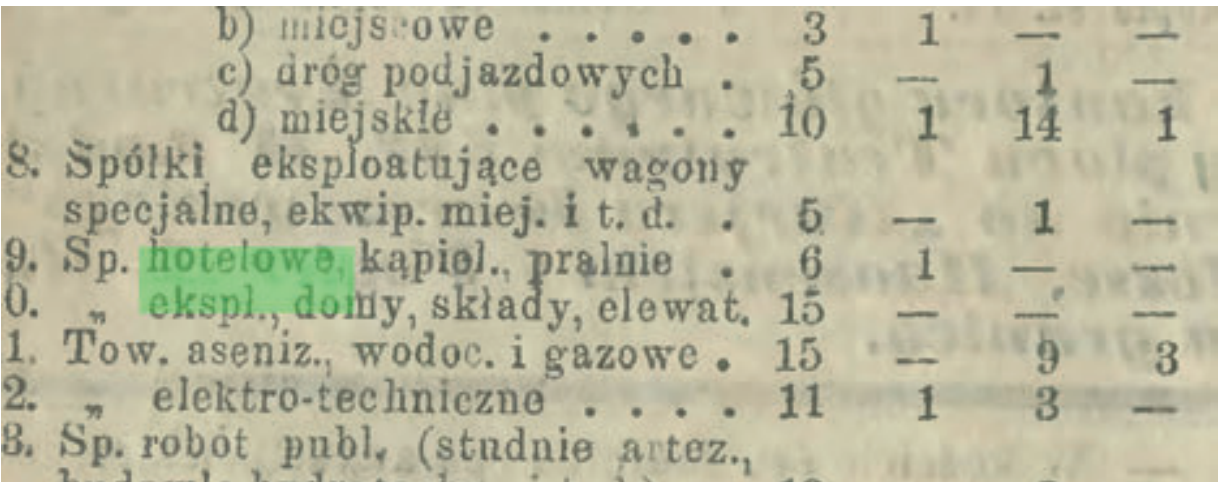


Stary renomowany hotel familisy nowourzadzony. 200 pokojów gobeinnye) od 1 florena poczawbzy, kęcznie $z$ ushuga i swiattem. C. K. biuro telegraficzne i telefonów na mejs u. Korzystne polozenie dla zwiedzających wystawę jutuleuszowi. Ceny niepodwyższone. J worce koiejowe i przystanki parowców w najbliz. szom rasiedztwie. Tramwaje $\mathbf{f}$ omnibusy hotelowo wo ws ystkich kiernnkach. Znakomita restauracja, winda osobowa. F. M. MAYER Wiaściciel.

\section{GLA ZAKLARÓW KAPPELOWYCH i DLA LETWHKÓW,}

Lawn-Tenn s, Krokiety. Badminton, Cricket, Boccis, Gra ro Zabs, Rakioty, Wolanty,_Kregle

Bylo to 0 godzinie dwunastej $\mathrm{w}$ nocy.

W hotelu pod „zlotym lwem" w X. panowala cisza grobowa. Tylko na ganku slyszano jeszcze leniwe stąpanie. Był to sluga hotelowy czyli jak go najnowszą polszczyzną nazywają hauslinecht, Stach, ktory chodzil ode drzwi do drzwi, aby zbieraé buty i buciki, wyczekujące czyszczącej jego ręki.

Do polowy spelnil juz missyę swoją i nic nadzwyczajnego w tym czasie się nie wydarzyło.

nerwy, to teź opowiadanie tego straszliwego zajścia nie zmieniło wcale jego twarzy, chociaź serce żywiej zakołatało. Oświadczył, że gotów jest pójść na policyą, co obie damy wraz z kelnerem $\mathrm{z}$ wdzięcznością przyjęly.

Wtem, gdy portyer już chciał odchodzić, uslyszal gwaltowne dzwonienie a bramy hotelowej. Pobiegl więc spiesznie na dót.

Ale gdy bramę otworzył odskoczył przeražony, bo dwaj żandarmi weszli do domu, a Stach za nimi.

\begin{tabular}{|c|c|c|}
\hline $\begin{array}{l}\text { ataoyes, } \\
\text { yt Mont } \\
\text { urwisty } \\
\text { i oót oi } \\
\text { goh nad }\end{array}$ & 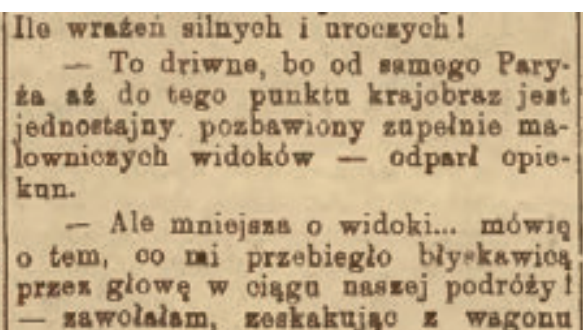 & 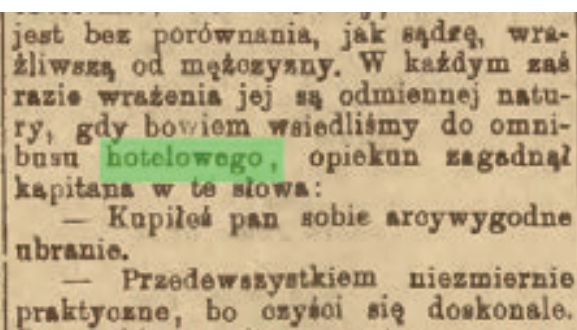 \\
\hline
\end{tabular}


wami oświetlono jak najrzęsiściej. Pod wplywem wesolego obiadu i dobrego powietrza obrazek ten wydał się wszystkim ponętnym. Podobał się i pani Elizie:

- Pamiętasz, Henryku, ogródek hotelowy w Kairze?

- A tak, masz racyę, - a muie to jeszeze przypomina jeden obrazek z Louvre'u - szkola francuska-koniec przeszlego wieku-nie pamiętam już ezyj...

szeze dokladal. Jaka to szkoda, rzekł Weigel, ze Matejko nie umie ani po francusku, ani po niemiecku; na wiosnę bylem \% nim razem we Wiedniu; jak go tam przyjmowali? ma on u ministra wielkie znaezenie, a u innyeh w Wiedniu wielkie poważanie; gdyśmy stanęli w jednym hotelu, to hotelowy odźwierny, widząe mię idącego z Matejka, zapytal się, ezy to jest Matejko? powiedzialem mu, tak

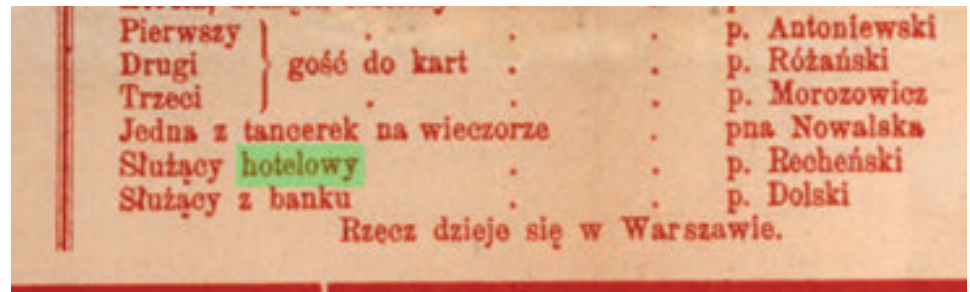

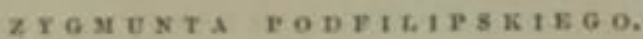

Pocieszaliśny się temi przypuszezeniami, ale wesolose gasla. Fred przestal graé na fortepianie.

Okolo ósmej słuźący hotelowy wprowadził starego posłańca w ezerwonej czapce, który oświadezył, że mu kazali ,oddaé ten list do rąk własnych jaśnie hrabiego Nadfilipskiego".

- Dawaj, ośle!-zawołal pan Zygmunt, wyrywająe mu list z rąk. 
który ubrak się $w$ insygnia kościelne $w$ parterowym pokoju hotelu, poczem w asystencyi kleru, w którego gronie znajdowal się ślepy i sędziwy k8. Dufresnc, adal się do pokoju, w którym spoczywaja zwloki cesarzowej. Ruch hotelowy nie ustal ani na chwilę, a podezas modłów nad zwlokami odzywaly się dzwonki z pokojow i sluzba przebiegala przez korytarze.

\section{- Komisga kolonizaeyjma kapila
dobra Turuowo za 627 tysiecy urak od pana
Yekelburga. \\ - W Jablonowle okradt zlodzioj wo ínice hotelowego i ukradi mu catery pary obu wia, srobrny segarek i láncussek.}

król hotelowyeh przedsiębiorstw, jak Flagłer, król parceli budowlanych, jak Astor, król wagonów, jak Pullman, król prasy, jak Pulitzer, i wielu, wielu innych.

Po wyjścin z kościoła zaszły do restauracji hotelowej na obiad, poczem panna Chatelain wyprawiła do pani Lagarde depeszę $\mathrm{z}$ zawiadomieniem - rychłym przyjeździe.

- No, to i ja także - odrzekłem, przekonany.

Zastaliśmy ją samą w pokoju hotelowym, otoczoną kuframi, jak na długạ podróż. Byla ubrana czarno, co dodawało blasku jej bladej twarzy i jasnym włosom, uwydatniało też piękne linie wynioslej postaci. Oczy, zwykle nie- 


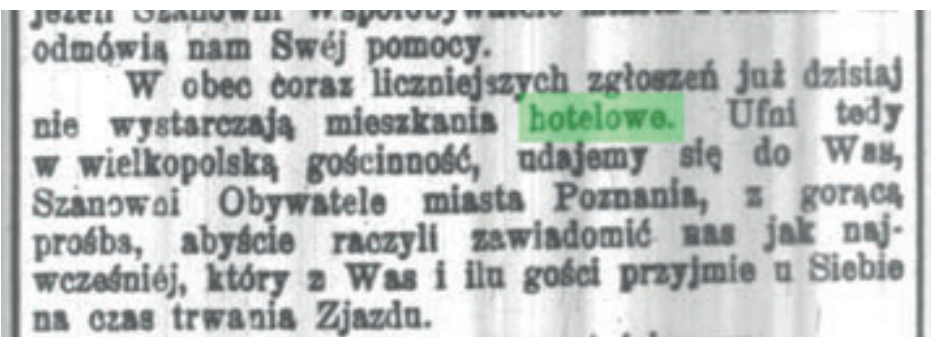

\section{sam, jako amator, brał udział w takiej walce. \\ Próes tego w swoin hotelu usłyszałem dźwięk mowy polskieis to themacz hotelowy (trzvmany do iezyków}

\section{\#I}

iść ręka w rękę z kimś

biuètn wynika, zo wszystko pozostac ma tak, jak bylo dotąd Dalej widocznem jest, ze w sprawie ugody istnieje wiele punktów, co do których iść moźna ręka w rękę ze stronnictwami, opierającemi się na prawno-państwowej podstawie i to nie tylko co do prowizorynm, ale takze co do definitywnego uregulowania sprawy. W kaźdym zaś razie moźliwem było zabezpieczenie normslnego toku obrad. Wszystko to moźna było aczynič bez narażenia liberalnego programu.

\section{izba handlowa}

\begin{tabular}{|c|c|}
\hline 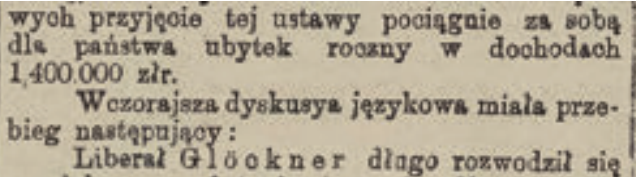 & 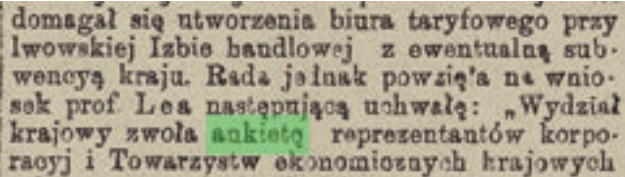 \\
\hline
\end{tabular}

publiczne, liezące w swem gronie ludzi, naleźycie z wymaganiami i stosunkami lesnietwa krajowego obeznanych. Należaloby więe postaraé się o takich przedstawicieli w państwowej Radzie kolejowej (w krajowej Radzie kolejowej nasze Towarzystwo lesne ma w mysl ustawy swego reprezentanta) w towarzystwach gospodarezych, w izbach handlowych, w wydzialach gieldowych, w specyalnych ankietach i zjazdach, ogólnej polityki handlowej dotyczących, a nawet dążyc, na wzór niemieckiej Rzeszy, do ustanowienia technikow leśnych przy zagranieznych reprezentacyach naszej monarchii jako referentów w sprawach lesnietwa $\mathrm{i}$ handlu drzewnego. 
\# J

jarowiniecki

xtore wlasnie studyowas.

Priódl "Familijny wieczorek" kompletnie nie ponósoi się, a co gorsza fiasko nastąpilo w obeorazed marzeczonego Loli, któr ote. Towsrzystwo bylo w kwaśnym humorze, jedna tylko Lola nie wiedziala dobrze 0 co ohodzi.

jednoroczna służba wojskowa

Cheñc wstąpić do apteki naležy przedewszystkiem wykazać się §swiadectwem $z$ ukończonej $z$ dobrym postępem 6 klasy gimnazyalnej i potrzeba mieć jaki taki mająteczek. Praktyka w aptece trwa przez 3 lata, w którym to czasie otrzymuje uczeń wikt i pomieszkanie, lub odpowiednie za to wynagrodzenie. Po skoniczonej 3-letniej praktyce składa on egzamin z chemii, nauk przyrodniczych, towaroznawstwa, znajomości reecptury i laboratoryum, poczem zostaje asystentem (podaptekarzem). Na mocy tego egzaminu ma asystent prawo do jednorocznej słužby wojskowej i zobowiązany jest zapisaé się z nadchodzącym pażdziernikiem na 2-letni kurs farmacyi na wszechnicy, jeżeli ehce wogóle zostać kiedys samoistnym aptekarzem, lub tylko zarzạdeą albo dzierżaweą apteki.

jedyny w swoim rodzaju

prass bawarska. Z okazyi otwaroia w Monaohinm wystawy maszyn odbywale się uroczystódé z pochodami przez miasto na oześć księoia rejents. Uroozystośd ta zrobila poniekqd fissko. Upamiętnil ją przytem epizod jedyny $w$ swoim rodzsju. Oddzielne trybunę przestrons i okszals, z pulpitami do pisanis itd. wrniesiono dle dziennikarzy. Otóz kiedy dziennikarze zajęli miejsos, jakis ozlonek ko-? 
język urzędowy

Oba powinny byé językami urzędowemi we wszystkich władzach i arzędach krajowych w Czechach, a urzędnicy krajowi $\mathrm{i}$ państwowi musza w jednakim stopnin władać niemi. Wszystkie publiczne nazwy, napisy i pieezęcie powinny być ezeskie i niemieckie, a równouprawnienic jęykowe ma byé tak przeprowadzone, aby zarówno państwowe jak $\mathrm{i}$ autonomiczue władze załatwiały sprawy i wydawały orzeezenia w tym języku, w jakim daną sprawę do tych władz wniesiono.

\section{\#K}

kakao w proszku

Kakao I czekolada firmy Riese \& Piotrowski w Warszawie, nadestane przez Zarząd Wystawie Hygienieznej, przy rozbiorze chemieznym daly wyniki nastẹpujące:
A) Kakao w proszku.

kamień szlachetny

najtwardszym mineralem. Niektóre kamienie szlachetne są zabarwionym korundem, i tak korund niebieski nazywa się szafirem; korund pięknie czerwony $\mathrm{rubine} \mathrm{m}$. Nieczysty korund nazywa się szmirglem i w stanie proszku lub ziarnek używa się do szlifowania i polerowania kamieni, metali i t. p.

kancelista

Kancelista sądow $\mathrm{y}$ w Nadwórnej Jozef Kutschera przy przejściu w stan spoczynku otrzymal tytul i charakter oficyala II klagy. Ankiøta w kwestyl żydów gallcyjskich zwolaną zostala do Wiednia przez tamtejeze Stowarzy- 
kasa chorych

\section{Kasa chorych}

dla współpracowníków aptekarkich prey Galiegj. Tow. farmac. „Unitas" Krakowie jedyna instytucya samopomocy koleżeńskiej w razie choroby; zatwierdzona przez Wys. c. k. Mlinisterstwo i zostajn̨ca pod kontrolą Wys. Władz ulbezpiecza swych ezłonków pod warunkami korzystniejszymi, jak wszelkie inne tego rodzaju zakłady.

kasa pożyczkowa

\section{W sprawie kas Reiffeisena odbyła się} w Tow. Kółek rolniczyeh ankieta na ktorej wyrażono opinię, iż te kasy są wielce pożądane dla włościan 1 że Wydział kraj. wraz z Radami powiat. powinien je jaknajsilniej popierać równolegle z kasami pożyczkwemi-

kasa Reiffeisena

\section{W sprawie kas Reiffeisena odbyła się} w Tow. Kółek rolniezyeh ankieta na ktorej wyrażono opinię, iż te kasy są wielce pożądane dla włościan 1 że Wydział kraj. wraz z Radami powiat. powinien je jaknajsilniej popierać równolegle z kasami pożyczkwemi-

kodeks terezyański

trag) kodeksu terezyañskiego (III. 19 n. 100.). Przeciwnie SCHEY str. 397 twierdzi, że przy przyjęciu podróżnego przychodzi do skutku rzeczywisty, a więc nie domniemany kontrakt składu. Gdyby tak bỵto, przepis \$. 970 . u. c. byłby najzupełniej zbytecznym. 
koleje lokalne

lejnictwa, dla ułożenia projektu ustawy

o kolejach lokalnych czyli niższo-rzędnych, (zob. koleje lokalne). Do ankiety powoluje się tylko ludzi fachowych. Różnica między ankietą a komisyą leży w tem, iz̀ do komisyi powoluje jakieś ciało, (n. p. Sejm, Rada gminna), ludzi wchodzących w skład te goz̀ ciała (więc Sejm posłów, Rada

kolej żelazna

WSZYSTKIE DZIAŁY BOGATO ILLUSTROWANE.

Premje gratisowe:

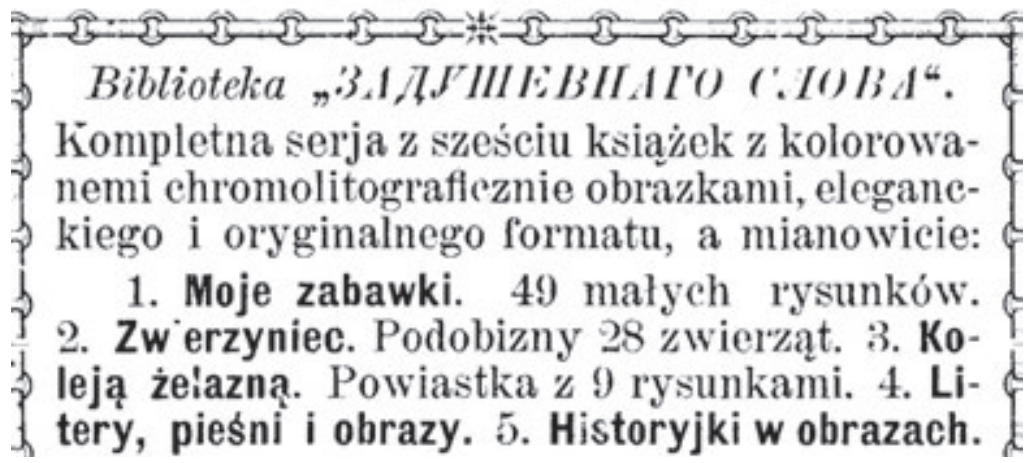

kortezy

Kortezy albo Cortes. Tak nazywa się w Hiszpanii i w Portugalii parlament czyli sejm, składający się $\mathrm{z}$ dwóch Izb. Dawniej były kortezy zgromadzeniem stanów na dworze (scorte znaczy dwór). 
korund

Studya teoretyczno-doświadczalne przeprowadzone niedawno przez referen'a wykazaly, że glinka z nadzwyczajną latwoścį̧, wydziela się ze stopów krzemionkowych w postaci krystalicznej korundu, jeżeli ilość jej w stopie jest więk. szą od wyrażonej w stosunku $\left(\mathrm{Na}_{2} \mathrm{O}+\mathrm{K}_{2} \mathrm{O}\right.$ + (aO) : $\mathrm{Al}_{2} \mathrm{O}_{3}=1$. Nadmiar glinki przeistacza się w korund, a pozostala jej część tworzy z zasadami i krzemionką zwiß̨zki glinowo.krze-

wiające domieszki. Jest po dyamencie najtwardszym mineralem. Niektóre kamienie szlachetne są zabarwionym korundem, i tak korund niebieski nazywa się szafirem; korund pięknie czerwony $\mathrm{rubine} \mathrm{m}$. Nieczysty korund nazywa się szmirglem i w stanie proszku lub ziarnek używa się do szlifowania i polerowania kamieni, metali i t. p.

Ḱorund, kamień czyli minerał, będący skrystalizowanym tlenkiem glinowym, często zawierającym inne zabarwiające domieszki. Jest po dyamencie najtwardszym minerałem. Niektóre ka- 
korundowo-feldspatowy

glinkowe, varazo do korunau zbizone co do samego powstawania i skłndu. Między innymi p. J. M. osobiście zebral na Uralu i opisal skaly korundowo-feldspatowe, wystepujace tam w wiel. kich masach. Należą iu : 1) skała anortytowokorundowa, nazwana przez referenta kysztymitem, 2) ortoklazowo-korundowa, wyróżniona jako pegmatyt korundowy, wreszcie 3) syenit korundowy, będący mieszaniną ortoklazu, korundu i miki.

korundowy

ka skal wybuohowych nie wyznaczyla dotąd -miejsca dla skal korundowych, p. J. M. proponuje poddzial skal wybuchowych, a właściwie t. zw. magm, czyli roztworów krzemionkowych ognisto-plynnych, przez których krystalizacyą powstaja owe skaly, na trzy wielkie gromady :

1. Protokul posiedzenia poprzedniego zostal odezytany i przyjety.

2) Pan J. Morozewicz znkomunikowal referat: ${ }_{n} 0$ skalach korundowych".

Studya teoretyczno-doświadezalne przeprowadzone niedawno przez referenta wykazaly, że glinka z nadzwyczajną latwością, wydziela siẹ ze stopów krzemionkowych w postaci krystalicz- 


\section{korupcyjny}

menci dawnego funduszu gadzinowego znowuby się atawili; nie ulega watpliwości, że juź dziś wietrza żer. Tego rodzaju fundusze dysponycyjne, mające slużyé celom politycznej walki, zmieniają sie czasem zbyt latwo w fundusze korupcyjne. Pojednawezo taka polityka nigdy nie bedzie oddziaływała - a przeciez rzad popisuje sie pojednawczością, przecinnie naostrzać będzie róźnice aż do ostateczności. Sadzimy. że wszrstkie za-

szkodanal" dalej od slów: "Albo jak mamy" do: "Wolcnlows" nastepnio od stón: "Trudno sie jednakże" do: npanama cbjetych", c. "Galicyjska panama" od slow: "Wasze to korupeyjne rządy" do końca, zawierają zna-

\section{koryfeusz}

lepiej siq̨ oplaca. Specyalistów mamy obocnie $\mathrm{w}$ każdej galęzi pracy ludzkiej - mamy ich téz w cechu rzezimieszków. Do najwybitniejszych koryfeuszy cechn zlodziejskiego należą bezsprzecznie rzezimieszki hotelowi i im to zawdzięcza cala korporacys wię-

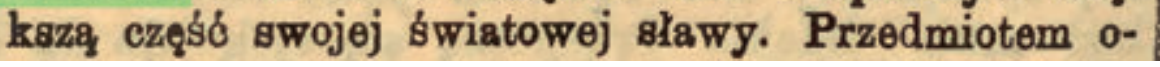

kostjum wyścigowy

zasłużył na drugą nagrodę. Jeden zaś ze znanych wyścigoweów wpadł na niezbyt odpowiedni leez dosyé oryginalny pomyst: kostjum miał wyścigowy, maszynę okręconą różnokolorową materja a nad kierownikiem łuk, z przodu którego był napis „amator“ $z$ drugiej zaś strony ..bierze tylko pieniądze“, które mialy initować powieszone rozmaitej wielkości woreczki; w ramie widnial napis: "patent na amatora“. 
kroplomierz

Trituratio hydrarizyri eum Ianolino an part. aequales, kilo 3 zkr. $90 \mathrm{ct}$

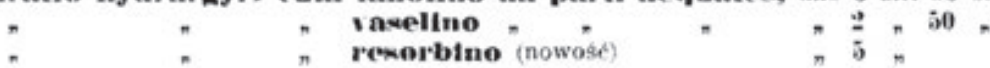

Utrzymuje na składzie wazniejsze materyaly apteczne, hegary blaszane i szklane, szkło apteczne, termometry maksymalne, kąpielowe i ścienne, flaszeczki-kroplomierze, zakraplacze, p̧̧zelki, pęzle do gardla, worki na lód, wstrzykawki szklane całe, lub w oprawach cynowych albo kauczukowyeh, alkoholometry, lampki spirytusowe, knlbki szklane $i$ wiele innych utensyliów zawartych w cennlku.

krzyżowy ogień pytań

Przedsiębiorców - jakkolwiek zaproszonych było wielu - stawiło się zalodwio 20 , zo sfor robotniczych zaś wzięlo udzial 189 kobiat i 59 mężczyzn. Ankieta miala wiele klopotu, zanim się dowiedziala od każdej z uczestniczek cokolwiek o stosunkach pracowni, w których byly zatrudnione. To jednak, co za pomoca krzyżowogo ognia pytan wydobyto, bylo wielce pouczającem. Wiadomo, że w wielu

kwaśny humor

Wora wlasnie studyowas

${ }_{n}$ Familijny wieczorek" kompletnie nie po-

wiódl" się, a co gorsza fiasko nastąpilo w obeonósoi narzeczonego Loli, któremu ohciano pokazad, te i dwór Jarowinieoki ma swojego poete. Towarzystwo bylo w kwaśnym humorze, jedna tylko Lola nie wiedzila dobrze o co chodzi.

kysztymit

glinkowe, barazo do korunau zblizone co do samego powstawania i składu. Między innymi p. J. M. osobiście zebral na Uralu i opisal skaly korundowo-feldspatowe, występujące tam w wiel. kich masach. Należą tu: 1) skala anortytowokorundowa, nazwana przez referenta kysztymitem, 2) ortoklazowo-korundowa, wyróżniona jako pegmatyt korundowy, wreszcie 3) syenit korundowy, będący mieszaniną ortoklazu, korundu i miki. 
korundowy

1. Protokul posiedzenia poprzedniego zostal odczytany i przyjety.

2) Pan J. Morozewicz znkomunikowal referat: „0 skalach korundowych".

Studya teoretyczno-doświadczalne przeprowadzone niedawno przez referen'a wykazaly, że glinka $\mathrm{z}$ nadzwyczajną łatwością, wydziela się ze stopów krzemionkowych w postaci krystalicz-

Kreteńczyk

- W Kasei wguiali admiratowie pray końcu swych rzagdów odezwe do Kreloń izy. ków. W odezwio przyrzekraja sdmirał owie opie re dla tureckiego sztandarm $j$ docosza o nominayyi ksipois Jerzogo vadbomiaszem wyapy Kroty na trzy lats pod warankiem aząnin zwiorzshnokici sultaríkiej. Ta zwierzohnoso sułtadaka bedzio tylko imienns, gdyt W ninzam win hedria ain móol miaszad do moadk..

król prasy

król hotelowych przedsiębiorstw, jak Flagłer, król parceli budowlanych, jak Astor, król wagonów, jak Pullman, król prasy, jak Pulitzer, i wielu, wielu innych.

\section{król wagonów}

król hotelowyeh przedsiębiorstw, jak Flagler, król parceli budowlanych, jak Astor, król wagonów, jak Pullman, król prasy, jak Pulitzer, i wielu, wielu innych. 
krzemionkowy

2) Pan J. Morozewicz zakomunikowal referat: "0 skalach korundowych".

Studya teoretyczno-doświadczalne przeprowadzone niedawno przez referen'a wykazaly, że glinkn z nadzwyczajną latwością, wydziela się ze stopów krzemionkowych w postaci krystalicz-

księga hotelowa

szkali oni w jednym z hoteli przy ulicy Fryderykowskiej i poczynili ogromne zakupy, wymieniając w ten sposób papiery wartościowe na sumę 25,000 rub., skradzione w Sewastopolu. Papiery zatrzymano w bankach berlińskich. W księdze hotelowej złodzieje zapisali się jako Schwarzmann z Wilna i Feuer z Londynu.

kuć żelazo póki gorące

piewa, by kuć zelazo pólai gorace $i$ korzystać z czasu od lat 20 do 30 . Co sie tyczy wdów, to statystyka wykazuje zadziwiajacy wynik, iż widôki ich zamążpójscia wogóle znacznie przewyższaja widoki panien. Jedynie w wieka od lat 25 do 30 ostatnie muja riawielkie "for," suto jednak wrrórnane we wszystkich in- 
kysztymit

glinkowe, bardzo do korunau zbizone co do samego powstawania i sklndu. Miegdzy innymi p. J. M. osobiście zebral na Uralu i opisal skaly korundowo-feldspatowe, wystepujace tam w wielkich masach. Należą tu: 1) skała anortytowokorundowa, nazwana przez referenta kysztymitem, 2) ortoklazowo-korundowa, wyróżniona jako pegmatyt korundowy, wreszcie 3) syenit korundowy, będący mieszaniną ortoklazu, korundu i miki.

\#L

laboratoryum

Chenge wstąpić do apteki należy przedewszystkiem wykazać się șwiadectwem $\mathrm{z}$ ukoniczonej $\mathrm{z}$ dobrym postępem 6 klasy gimnazyalnej $\mathrm{i}$ potrzeba mieć jaki taki mająteczek. Praktyka w aptece trwa przez 3 lata, w którym to czasie otrzymuje uczeń wikt $\mathrm{i}$ pomieszkanie, lub odpowiednie za to wynagrodzenie. Po skoniczonej 3-letniej praktyce składa on egzamin z chemii, nauk przyrodniczych, towaroznawstwa, znajomości receptury i laboratoryum, poczem zostaje asystentem (podaptekarzem). Na mocy tego egzaminu ma asystent prawo do jednorocznej słužby wojskowej i zobowiązany jest zapisać się $\mathrm{z}$ nadchodzącym pażdziernikiem na 2-letni kurs farmacyi na wszechnicy, jeżeli ehce wogóle zostać kiedys samoistnym aptekarzem, lub tylko zarzạdcą albo dzierżaweą apteki.

lampka spirytusowa

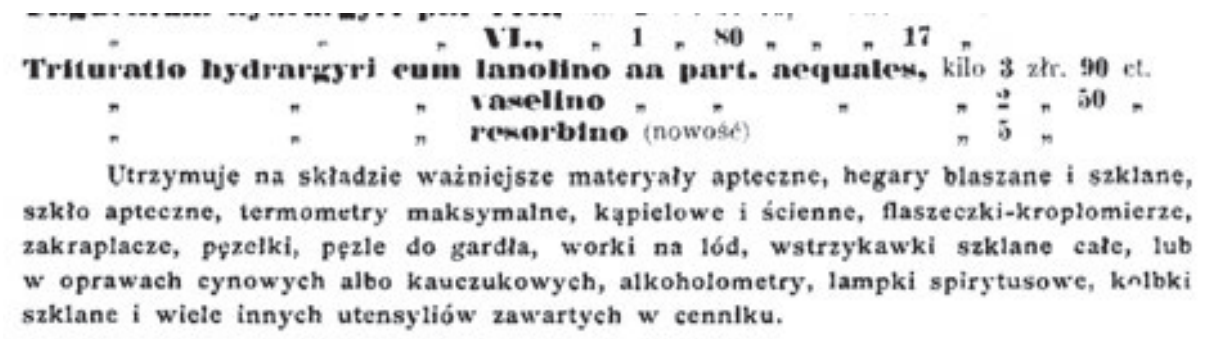


libération

\section{(Dokohczenie).}

Maurycy Pujo jest współpracownikiem pisma $L$ 'Art et la Vie; rozumie on krytykę na swój sposób, jest to dla niego rodz j ankiety 0 ideach moralnych naszego czssu; ankietę ows czyni Pujo, sby dojéć przez szereg liquidations do wlasnej liberation. W chaosio dz̨żeń wybiora on najbardziej znaczące, aby osiągnąc wyrobienio ezlowiecze. Krytyks więc u $\mathbf{M}$.

list przewozowy

W roku 1897 to jest od 1 styeznia do 31 grudnia obrót tytoniowy wynosiz $39075 \mathrm{z}$. 22 et., zysk $z$ drobnej sprzedaży wynosił w tym czasie 253 zł. 64 ct., zaś obrót w stemplach, listach przewozowych i blankietach wekslowych wynosil $6512 \mathrm{zl} .91$ et, od sprzedaży tych znaczków wartościowych będzie pobierał składownik pół procent.

list przewozowy międzynarodowy

$$
\text { (Do artykutu } 6 \text { umow y). }
$$

§ 2. Listy przewozowe międzynarodowe wygotowywać należy na blankietach, których wzór podaje załączka $2^{1}$ ). Blankiety te powinny byé wydrukowane do posylek zwyezajnych na białym, do pospiesznych na ciemno-róz̀owym papierze, a zgodnośc ich $\mathbf{z}$ dotyezącymi przepisami umowy niniejszej potwierdzona być ma wyciśnięciem 
literatura gwiazdkowa

Grudzień. Literatura gwiazdkowa.-Ankiets p. Kowalskiego co do stanu zdrowis studentów uniwersytetu warszawskdego. -

Lola

xcora wlasnie studyowas.

nFamilijny wieczorek" kompletnie nie powiód r się, a co gorsza fiasko nastąpilo $w$ obeohośi narzeczonego Loli, któremu ohoiano po* Łarad, te $\mathrm{i}$ dwór Jarowinieoki ma swojego poetę. Towsrzystwo bylo w kwaśnym humorze, jedna tylko Lola nie wiedziala dobrze 0 co chodzi.

loterya fantowa

Wielka loterya fantowa na dochód Towarzystwa wzajemnej pnmocy ręzodzielników i przemysłowców $w$ Krakowie, odbędzie się $w$ niedzielę

\#M

magistrat

Gdy Wydziad krajowy pracowad nad ułożeniem ordynacyi wyborczej dla 30 miast i zaprosił ankiete w tym celu, aby zasiągnąé także jej zdania, przedstawiona hyła tej ankiecie ordynacya wyboreza, w ktćrej mieściły się postanowienia, iż członkowie Wydziału powiatowego nie moga być wybruni na czlonków magistratu, (a zatem to, czego dotad nie było, chciano w ten sposób 


\section{mająteczek}

Cheąc wstąpić do apteki naleźy przedewszystkiem wykazać się świadectwem $\mathrm{z}$ ukoniczonej $\mathrm{z}$ dobrym postępem 6 klasy gimnazyalnej i potrzeba mieć jaki taki mająteczek. Praktyka w aptece trwa przez 3 lata, w którym to ezasie otrzymuje uczen wikt $\mathrm{i}$ pomieszkanie, lub odpowiednie za to wynagrodzenie. Po skoniczonej 3-letniej praktyce składa on egzamin z chemii, nauk przyrodniczych, towaroznawstwa, znajomości receptury i laboratoryum, poczem zostaje asystentem (podaptekarzem). Na mocy tego egzaminu ma asystent prawo do jednorocznej słužby wojskowej i zobowiązany jest zapisać się z nadchodzącym pażdziernikiem na 2-letni kurs farmacyi na wszechnicy, jeżeli chce wogóle zostać kiedy§ samoistnym aptekarzem, lub tylko zarzạdea albo dzierżaweą apteki.

\section{Matejko}

szeze dokladal. Jaka to szkoda, rzekl Weigel, że Matejko nie umie ani po franeusku, ani po niemiecku; na wiosnę bylem z nim razem we Wiedniu; jak go tam przyjmowali? ma on u ministra wielkie znaczenie, a u innych w Wiedniu wielkie poważanie; gdyśmy stanẹli w jednym hotelu, to hotelowy odżwierny, widząc mię idącego z. Matejkạ, zapytal się, exy to jest Matejko? powiedziałem mu, tak

\section{maturzysta}

miotem względnie obowiązującym. "Przystęp do uniwersytetu przysłużać będzie
maturzystom obydwóch kierunków."

\section{mączka kartoflana}

dróży stanowi niezwyłkla ilość: đólawi, ezapli, dzikich kaczek i imnego ptactwa wodnego brodzącego pojedynezo lub ealemi stadami zrywającego się co cinwila.

Do Annopola przyplynęliśmy o godzinie 10 z rama. Statek dobił do brzegu w miejseu gdzie wznosi sie spora fabryka parowa mączki kartoflanej i gdzie zwoża drzewo buduleowe z lasów okolieznych do splawu po Wiśle. 
minister rolnictwa

- Walka z grủ̇licą na Węgrzech. W celu obmyślenis árodkow, za pomocą któryeh możnaby walezyé przeciwko szerzenin sie grużlicy wśrod bydlı, zwołal węgierski minister rolnictwa w b. m. snkietę do Pesztu. Ankiets orzekls, że w obecnej chwili najwięcej odpowiednim f́rodkiem jest oddzielenie zdrowych zwierzạt od uznsaych za chore na podatawie szezepienis tuberkuliny, które ms się wykonać ns koszt pá́stwa. Uznano aastępuie za bardzo pożądane zakazanie przywozu $z$ zagranicy zwierz̨̧t reagują-

minister sprawiedliwości

\section{Telegraficzne i telefoniezne wiadomości "Nowej Reformy",}

Wiedeh, 3 marca. Wiener Ztg. ogłasza: Minister sprawiedliwości przeniósł radcę sądowego i naczelnika sąu powiatowego Aleksandra $\mathrm{Z}_{\mathrm{g}} \mathrm{O}^{-}$ de -Fijalkiewicza w Zatorze do Kęt i zamianowal sędziami powiatowymi: sekretarza sqdowego $w$ Tyczynie Romana R g barkiegol

ministerstwo spraw wewnętrznch

- 'Specyfiki lecznicze. Ministerstwo spráw wewnętrznycl rozporządzeniom z d. 22 lipca b. r. zabroniło handlu rozmaitymi specyfikami leczniczymi, którym fabrykanci przypisuja iście eudowne własności, oraz krzykliwego, często przesadnego reklamowania artykulów, posiadającyeh pewien dodatni skutek leczniczy. Ministerstwo rozporzadziło, by micjscowe władze polityezne przekraczajłcyclı ów zakaz pociagały do odpowiedzialności sqdowo-karnej.

ministeryalny

wą dżnmy w Wiedniu, wezmą jăko réprezentanci rzşdu udzial: szef sekcyjny Stummer i radca mi nisteryalny Dr Kusy. 
moje dziecko

mnio! Zosta w mnie, ciocia! zamęozasz

- Tak, rozumiem, cierpisz teraz wiele, mnje dziecko, i masz zal do mnie, - za to póḱniej wdzięczną mi będziesz.

- Jestem nieszczęśliwą na cale kycie przez ciebie, ciocia! - wybuchnq. la Simona.

\section{\#N}

nadać czemuś charakter żartu

Pani Walerya odzyskala glos, widzago te prezes choial nadé oalemn zlarzenin oharerter tiarta.

- Czy mój mąz jest czlowiekiem smieeznym? ozy mu nie wolno trzymad administracji? pisad na blankietzoh ? W Niemozech...

Prezes uchwycil is za rękę $\mathrm{i}$ przerwal.

nadkomisarz

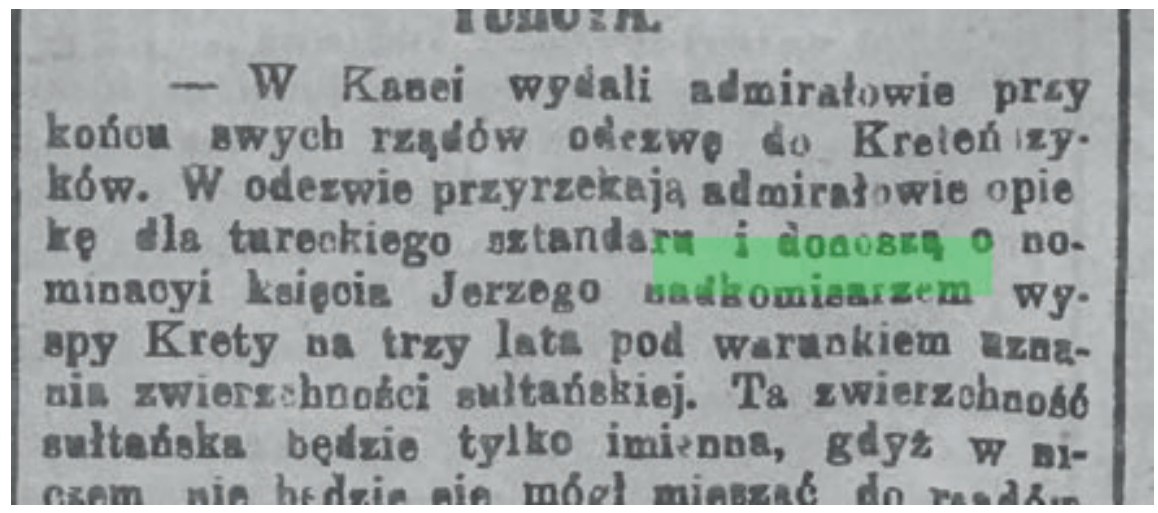




\section{FUiGith.}

- Jak wczorajsze telegramy donosity ma niebswem ksiaze Jerzy, nowozamianuwsny nadkomiserz Krecy, z wieika okusałorcis udá eie na wyspe. Piszą takze, iz kaiq̨ze Jerzy zobowiazal się uznać zwierzchnośc turecka nad Kreta i skoro tylko tam przybedicie, zapiadoo

Krakków, 26 lipca. Dziśs o godz. 6 rano prze-
jechal przez Kraków pociąg, wiozący króla rumuń-
skiego Karola z następca, tronu. Na dworcu stawili
się wyżsi urzędnicy kolejowi z Wiednia, z Krakowa
zas nadkomisarz Swolkien, zastępujący dyrektora po-
licyi. Prezydent ministrów s $\mathrm{t}$ o u r d z a wysiadł
z wagonu i przez kilka minut rozmawiał z Swolkie-
nem, wspominając mile Kraków, znany mu z lat
młodocianych.

napój alkoholiczny

6) Dezinfekcya. 7) Gimnastyka lecznicza i t. d. 8) Odzienie.

III. Nanka lekarska: 1) Anatomia. 2) Fizyolugia. 3) Psycho-fizyologia. 4) Patologia : a) ogólna, b) szczegółowa. 5) Środki farmaceutyczne. 6) Seroterapia i serodiagnostyka, organoterapia. 7) Narzędzia chirurgiczne (ginekologia, oknlistyka, laryngologia, dentystyks etc.). 8) Elektroterapia i elektrodiagnoza (Roentgen).

IV. Środki spożywcze i odżywcze. 1) Przetwory mięsne. 2) Przetwory mleczne. 3) Przetwory mączne. 4) Konserwy. 5) Napoje alkoholiczne. 6) Napoje bez 
natrysk

Rzecz cała wyjaśniła się w ten sposób, że przemyślny kelner wyprzątnąć kazał dla nadliczbowych gości łazienkę hoteluwą, ustawił łóźka w miejsce wanien, ale zaponınial odjąć sznury otwierające natryski. Pani młoda pociągnęla za sznur, sprowadzający silną tuszę, pan mlody zaś odsunął nad sobą sito deszczowe i tak obojgu wydarzyla się pamiętna awantura, której nie każda mloda para podróżująca zażyje.

nauka lekarska

III. Nanka lekarska: 1) Anatomia. 2) F'izyologia. 3) Psycho-fizyologia. 4) Patologia : a) ogólna, b) szczegółowa. 5) Środki farmaceutyczne. 6) Seroterapia i serodiagnostyka, organoterapia. 7) Narzędzia chirurgiczne (ginekologia, oknlistyka, laryngologia, dentystyka etc.). 8) Elektroterapia i elektrodiagnoza (Roentgen).

na wypadek $c z e g o s ́$

W obaonej wojnie tedy nie grozi nieberpieczehutwo zniszozeris kablu, oo $\mathrm{W}$ innyoh wojnsoh morskioh s8w8ze sie dzieje. Wlaboiwe nieberpie ozehatwo nietylko $w$ tym wypedka, sle $i$ ne wypedek dalszyoh międzyne-

nekrologia

- Nekrologia. Stefania z Herbstów Windaki ewiczowa, wdowa po starszym kontrolorze poczt i telegrafow, zmarła wczoraj w Krakowie w 60 roku 
nie dać najmniejszego znaku życia

Od czasu wyścigów międzynarodowych t. j. od września r. p., Ł. T. C. nie dało najmniejszego znaku życia tak wewnętrznego jak i zewnętrznego. Zima tegoroczna, niedopisując salonowi lodowemu _. kazało

niemiłosierdzie

igreysik!"

Gromady ludzkio powinny wspólnio bawió siq, cieszyó, podziwiad, nawet plakaó; sq to bowiom wrrassenia szleohetne. Ale biads narodom, w których masy wspólnie ucza się nienawiści, niomikosierdzia, pogardy i t. d. aczuó, które prowadzą do driczenia Morder stwa $\mathbf{w}$ reymskioh oyrkach, palenie kacrey w Hiszpanii, rozmaito juden - i polenbece, nie tylko dla tego są zle, ze robily lab robiz

niewspółmiernie

Nietylko inteligenoya, alo i prostacy, nie-l tylko bogaci ale i mniej samokni, niotylko ohrresoijanie, looz i niechrzesoijanie powiuni: rosrastad się, doskonalió się i uszlachetniad. Inacroj polecsenstwo będzie rozwijalo się niewspólmiernie, czyli - będzie chorem...

Ale kto to wesystko ma srobió ? Kto jest powoleny do pracy nad szozęściem spoleozen 
niżej podpisany

Wiesci o nieurodzaju kartofli zatrwożyły miesekańców Łodzi i jej okolic, przejmując obawa, czy niearodzaj kartofli nie sprowadzi klęski glodowej, i potegujac z tej przyczyny zainteresowanie się tutaj ankietą, podjętą przez Kurjer warszawski.

Na szczesscie pokazało się, ze klęska tutaj nie zagraża.

Niżej podpisany opóźnił się $\mathrm{z}$ odpowiedzia na kwestjonarjusz Kurjera; pragnąc bowiem zgromadzić wiadomości żródłowe i wszechstronne i odwo-

niższo-rzędny

lejnictwa, dla ułożenia projektu ustawy

o kolejach lokalnych czyli niższo-rzędnych, (zob. koleje. lokalne). Do ankiety powołuje się tylko ludzi fachowych.' Różnica między ankietą a komisyą leży w tem, iz̀ do komisyi powoluje jakieś ciało; (n. p. Sejm, Rada gminna), ludzi wchodzących w skład tegoz̀ ciała (więc Sejm posłów, Rada

\section{nowo-mianowany}

cję akwarelli i gwaszu, doskonały w pomyśle, tonie i kolorycie, jest dziełem zmanego artysty rysownika p. M. Roszkowskiego.

Pan Antoni Fertner imieniem delegacji prosił nowo-mianowanego ezłonka by zecheiał zaszezyeić swą obecnością zabawę, jaka w tymże dniu wieczorem odbyé się miała na Dynasach $\mathrm{z}$ okazji przypadającej roczniev założenia .. Koła śniewaczego" War. 
\#O

odpowiedzialność sądowo-karna

- 'Specyfiki lecźnicze. Ministerstwo spráw wewnętrznych rozporządzeniem z d. 22 lipca b. r. zabroniło handlu rozmaitymi specyfikami leczniczymi, którym fabrykanci przypisują iście cudowne własności, oraz krzykliwego, ezęsto przesadnego reklamowania artykułów, posiadających pewien dodatni skutek leczniczy. Ministerstwo rozporzadziło, by micjscowe władze polityczne przekraczających ow zakaz pociągaly do odpowiedzialności sądowo-karuej.

ogrodniczo-pszczelniczy

Uregulowanie sadownictwa. Piszß̨ nam ze Lwowa:

Wystawa ogrodniczo-pszczelnicza poruszyla waźng̨ kwestye uregulowania sadownictwa w Galicyi, które dziśs w upadku staćby się mogło znakomitą pomocs dla gospodarstw rolnych. W tym celn zgromadzila się ankieta, zwolana staraniem prof. wiele J. Szyszylowicza.

W obradach wzięli udzial : dyr. wystawy p. Tynie- wano.

ordynacya wyborcza

Gdy Wydzial krajowy pracowal nad ułożeniem ordynacyi wyborczej dla 30 miast i zaprosił ankietę $\mathrm{w}$ tym celu, aby zasiągnąć także jej zdania, przedstawiona hyła tej ankiecie ordynacya wyboreza, w ktćrej mieściły się postanowienia, iż członkowie Wydziału powiatowego nie moga być wybrani na czlonkọ́w magistratu, (a zatem to, czego dotąd nie było, chciano w ten sposób

organoterapia

III. Nanka lekarska: 1) Anatomia. 2) Fizyolugia. 3) Psycho-fizyologia. 4) Patologia : a) ogólna, b) szczegółowa. 5) Srodki farmaceutyczne. 6) Seroterapia i serodisgnostyka, organoterapia. 7) Narzędzia chirurgiczne (ginekologia, oknlistyka, laryngologia, dentystyka etc.). 8) Elektroterapia i elektrodiagnoza (Roentgen). 
ortoklazowo-korundowy

glinkowe, barazo do korunau zblizone co do samego powstawania i składu. Miegdzy innymi p. J. M. osobiście zebral na Uralu i opisal skaly korundowo-feldspatowe, występujące tam w wielkich masach. Należą tu : 1) skała anortytowokorundowa, nazwana przez referenta kysztymi. tem, 2) ortoklazowo-korundowa, wyróżniona jako pegmatyt korundowy, wreszcie 3) syenit korundowy, będący mieszaniną ortoklazu, korundu i miki.

\section{\#P}

pagórkowatość

- Nawet dla spożyeia śniadania niechętnie schodziłem do kajuty.

Sandomierz dzięki pagórkowatości terenu, na którym się wznosi, ze statku przedstawia się bardzo wspaniale i większym o wiele aniżeli jest w rzeczywistości. Za-

pan młody

Rzecz cała wyjaśniła się w ten sposób, że przemyślny kelner wyprzątnąć kazał dla nadliczbowych gości łazienkę hoteluwą, ustawił łóżka w miejsce wanien, ale zaponınial odjąć sznury otwierające natryski. Pani młoda pociągnęla za sznur, sprowadzający silną tuszę, pan mlody zaś odsunął nad sobą sito deszczowe i tak obojgu wydarzyla się pamiętna awantura, której nie każda mloda para podróżująca zażyje. 
papier listowy

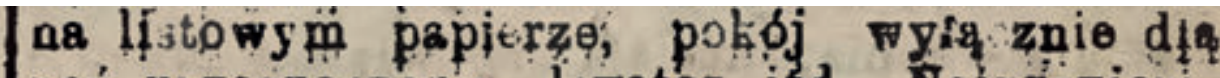
pań przezusozany, lavstor ifd. Najprzyjorg: deielo no vronhowaiusame de hntaln wno

parcela budowlana

król hotelowych przedsiębiorstw, jak Flagler, król parceli budowlanych, jak Astor, król wagonów, jak Pullman, król prasy, jak Pulitzer, i wielu, wielu innych.

parowóz

rs. 624. - zaplacono, akcje Banku rosyjskiego dla haudl! zewnelmnego rs. 419.50 zaplacono, akcje Bankn handlowego w Warszawie rs. 515. - zapłac., akcje Banku hand!ovego : Rydze rs. 544.zapłacon", akeje Bankn rosyjsko-chińskiego ts. 283 kop. - raplacono, akcje Towarzystwa aleksandrowskiego rs. 360 kop. - zaplacons, akeje Towarzystwa n'Bouhey" (rosyjskie Towarzystwo budowy parowozów) rs. 279 kop. - zapłacono, akeje rosyjsko-bel-

patologia ogólna

III. Nanka lekarska: 1) Anatomia. 2) F'izyolugia. 3) Psycho-fizyologia. 4) Patologia : a) ogólna, b) szczegółowa. 5) Środki farmaceutyczne. 6) Seroterapia i serodiagnostyka, organoterapia. 7) Narzędzia chirurgiczne (ginekologia, oknlistyka, laryngologia, dentystyka etc.). 8) Elektroterapia i elektrodiagnoza (Roentgen). 
patologia szczegółowa

III. Nanka lekarska: 1) Anatomia. 2) F'izyologia. 3) Psycho-fizyologia. 4) Patologia : a) ogólna, b) szczegółowa. 5) Środki farmaceutyczne. 6) Seroterapia i serodiagnostyka, organoterapia. 7) Narzędzia chirurgiczne (ginekologia, oknlistyka, laryngologia, dentystyka etc.). 8) Elektroterapia i elektrodiagnoza (Roentgen).

piąte przez dziesiąte

W kierunku umysłowym, panowała u adeptów cisza nieprzerwana przez ciąg praktyki, aź dopiero przy końcu 3-go roku, zaczęto ich nạpẹdzać „do książki ${ }^{\star}$. Uczyli się oni wiẹc "piąte przez dziesiąte", nie wiedząc właściwie czego się maja uczyc, i tak niedokształceni zdawali egzamina "na podaptekarzy* coram komisyi egzaminacyjnej, która ut aliquid fecisse videatur funkcyonowała. - Kształcenie ich odbywało się nie podług pewnych jednolitych reguł obowiązujących wszystkich aptekarzy, lecz podług upodobania czy przekonania pojedyńczych wychowawców tak, że adept otrzymywał

plamka zarodkowa

nasienne. Bezpośrednim rezultatem takiego polączenia się bywa wydzielenie na po. wierzchni jajka cienkiej błonki, która zabezpiecza je od niepotrzebnej nowej ilości plemników. Wkrótce bezbarwna "plamka zarodkowa" znika, zielony kolor jajka przechodzi w mniej więcej brunatny, czasami ciemno-czerwony, a blonka silnie grubieje, zmieniając się na trwałą, bądź gładką, bądz też wzorami tkaną powłokę. 
plemnik

zaś różnica między niemi a zoosporami polega na tem, że, będąc odosobnionemi, nigdy nie daja początku nowym niciom Oedogonium, lecz powoli gin̨. Pochodzenie tych elementów męskich czyli plemników nie u wszystkich przedstawicieli rodzaju bywa jednakie. U jednych taż sama nić, któ-

\section{Plemnie, plemniki zob. Mchy.}

Ten ostatni w niektórych razach różoicuje się w błonę falującą, pomocną przy ruchach plemnika, lub teź czasem redukuje się (np. u robaków oblych) do niewyraźnie skonturowanej brylki plazmatycznej, zdolnej do wykonywania ruchów pełzakowatych.

zaś różnica między niemi a zoosporami polega na tem, że, będąc odosobnionemi, nigdy nie daja początku nowym niciom Oedogonium, lecz powoli ginģ. Pochodzenie tych elementów męskich czyli plemników nie u wszystkich przedstawicieli rodzaju bywa jednakie. U jednych taż sama nic, kt6rej komórki utworzyly jajniki, wydaje w pewnych miejscach rząd krótkich komó- 
plenarny

Plenarny znaczy pelny, n. p. plenarne zebranie tyle co pełne zebranie,

plenipotencya

\section{Plenipotencya znaczy lo samo co}

pełnomocnictwo (zob.); plenipotent - pelnomocnik.

płodnik

reczek; a tych każda daje początek jednej parze plemników. Komórkę taką zwiemy anteridium czyli płodnikiem. U innych gatunków Oedogonium nić, produkująca jajniki, nigdy nie wydaje plemników; te ostatnie wytwarzane bywaja przez nici tylko do tego

pociag kurjerski

I Alleluja!

if = raejazd.

Pociągiem kurjerskim kolei Warszawsko-Petersburskiej wczoraj o $\mathrm{g}$. $10 \mathrm{~m}, 23 \mathrm{r}$. przybył na stacje Warszawa general-feldmarszałek Jego Cesarska Wysokośc Wielki Książę Michał Mikolajewicz. 
podaptekarz

Cheạe wstapié do apteki naleźy przedewszystkiem wykazać się șiadeetwem $\mathrm{z}$ ukoniczonej $\mathrm{z}$ dobrym postẹpem 6 klasy gimnazyalnej i potrzeba mieć jaki taki mająteezek. Praktyka w aptece trwa przez 3 lata, w którym to czasie otrzymuje uczeń wikt i pomieszkanie, lub odpowiednie za to wynagrodzenie. Po skoniczonej 3-letniej praktyce składa on egzamin z chemii, nauk przyrodniczych, towaroznawstwa, znajomości receptury i laboratoryum, poczem zostaje asystentem (podaptekarzem). Na mocy tego egzaminu ma asystent prawo do jednoroeznej słužby wojskowej i zobowiązany jest zapisać się z nadchodzącym pażdziernikiem na 2-letni kurs farmacyi na wszechnicy, jeżeli chce wogóle zostać kiedył samoistnym aptekarzem, lub tylko zarzạdeą albo dzierżawen apteki.

podbiegunowy

Gęsto się 0 nich prawi przy toastach, ale w rzeczywistości oddawna już nie robi się nic i ezlonek nieustosunkowany, któryby się zapuścił na zabawę towarzyską do klubu, znajdzie tam podbiegunowa atmosferę, która mu na zawsze odbierze ochotę do podobnych zachcianek. Dla tego też sprawo-

podgórski

- Ankieta w sprawie załoźenia rzeźni i targo wicy na bydlo opasowe w Podgórzu odbyla się w ostatnią środę w podgỏrskim Magistracie przy udziale posła Hermana Czecza, burmistrza p. Garbaczyńskie go, reprezentantów gminy oraz grona $080 \delta$ b faclıowych.

pojedyńczy

Osoba pojedyńcza lat srednich z kaucją, poszukuje filji pieczywa, obeznana z tym fachem odpowiednio. Wiadomośc ulica Podwal Nr. 40 , filja. 
pomiędzy innemi

stwo? Nareszcie, wzywa ankieta do podawania projektów reformy i stawia pomiędzy innemi pytanie, w jaki sposób należaloby uzupełnic plan nauk i sposób wychowania, aby szkoly realne i gimnazyalne czyniły zadosí potrzebom społeczeństwa.

\section{pomolog}

Kwestye powyższe przedstawil prof. Janczewski $w$ formalnych wnioskach, kt6ce zostały przez ankietę przyjęte jednomyślnie. Przemówienie dr. Szyszyłowicza spowodowalo ostateczne zalatwier: sprawy zajmującej ankietę - a mianowicie przez wybór komisyi z grosa znanych pomolog $\delta$ w dls każdej strefy klimatycznej, celem doboru 0 woców najlepiej odpowiadających warunkom naszego kraju. W skład takich komisyj ve-

popełniać fiasko

Arbeiter Zeitung twierdzi, ze Thun popelnia jedno fiasko za drugiem i widocznie sam siebie chce ludzić, aby się tylko dlużej módz utrzymać przy sterze. Dalej zarztica Thunowi, ie lekceważy konatytucje, gdyz odroczenie rady paḱstwa nie zostalo ogloszone w Wiener Ztg.

\section{posadomania}

cyi, o szkole francuskiej, o francuskiej posadomanii, o braku inicyatywy, o zbytniej przewadze ukeztalcenia teoretycznego nad praktycznem - to wszystko da się w pewnej mierze do nas zastusowac. I cala książka, a idziałalnośc Desmolins'a jest wzorem dla naszych wlasnych prac, którego po ankietach w rodzajn ankiety p. Kowalskiego powinno by podjąc okulo siebie spoleczeństwo. 
posyłka pospieszna

\section{(Do artykutu 6 umow y).}

§ 2. Listy przewozowe międzynarodowe wygotowywać należy na blankietach, których wzór podaje załączka $\left.2^{1}\right)$. Blankiety te powinny byé wydrukowane do posyłek zwyezajnych na białym, do pospiesznych na eiemno-różowym papierze, a zgodność ich $\mathrm{z}$ dotyezącymi przepisami umowy niniejszej potwierdzona być ma wyciśniẹciem

posyłka zwyczajna

(Do artykutu 6 umow y).

§ 2. Listy przewozowe międzynarodowe wygotowywać należy na blankietach, których wzór podaje załączka $2^{1}$ ). Blankiely te powinny byé wydrukowane do posylek zwyczajnych na bialym, do pospiesznych na eiemno-róz̀owym papierze, a zgodność ich $\mathrm{z}$ dotyezącymi przepisami umowy niniejszej potwierdzona być ma wyciśnięciem

poszpitalny

Wybór miejsca padnie, jak się zdaje, na jeden z
placów poszpitalnych od strony placu Wareckiego,
jaktrolwiek w tej mierze zadoej nchwały stanow-
czej jeszcze nie powzięto. Projekt ma byé nie-
bawem zlozony general-gubernatorowi warszaw-
skiemu.

powziąć jaką́s $s_{1}$ uchwałę w jakiejśs mierze

Wybór miejsca padnie, jak się zdaje, na jeden z placów poszpitalnych od strony placn Wareckiego, jakkolwiet w tej mierze zadoej uchwaly stanow. czej jeszcze nie powzięto. Projekt ma byé niebawem zloziony general-gubernatorowi warszawskiemn. 
powziąć zamiar

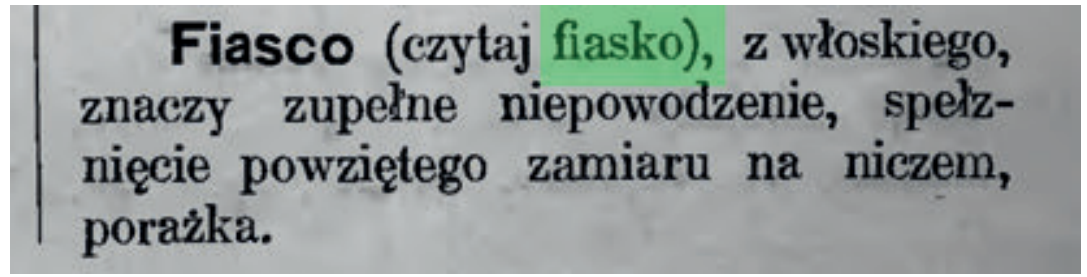

\section{prawo spadkowe}

Poniewaź coraz to jaśniej okazuje się potrzeba zmiany obecnego prawa spadkowego, przeto byloby pożąanem, gdyby przeprowadzono na obszarze calego kraju ankiete, opartą na zasięgnięciu opinii wladz politycznych, notaryuszów i sądów w sprawie zwyczajów spadkowych, podobnie jak to stalo sie w ostatnich latach w Bawaryi i w Prusiech, a prócz tego należaloby oczywiście przeprowadzić ankietę w gminach typowych na

Wprawdzie w ankiecie zwolanej wskutek polecenia Sejmu dolno-austryackiego, a obradować mającej nad projektem zmiany prawa spadkowego i tworzenia zagród (geschlossene Höfe) bral udzial z ramienia tamtejszego Namiestnictwa referent dla spraw rolniczych (Landesculturreferent),

2) Nr. 91 ex 1898 . Dz. p. p. iu. 8.

przetwory mięsne

6) Dezinfekcya. 7) Gimnastyka lecznicza i t. d. 8) Odzienie.

III. Nanka lekarska: 1) Anatomia. 2) Fizyologia. 3) Psycho-fizyologia. 4) Patologia : a) ogólna, b) szczegółowa. 5) Środki farmaceutyczne. 6) Seroterapia i serodiagnostyka, organoterapia. 7) Narzędzia chirurgiczne (ginekologia, oknlistyka, laryngologia, den. tystyka etc.). 8) Elektroterapia i elektrodiagnoza (Roentgen).

IV. Środki spożywcze i odżywcze. 1) Przetwory mięsne. 2) Przetwory mleczne. 3) Przetwory mączne. 4) Konserwy. 5) Napoje alkoholiczne. 6) Napoje bez 
przetwory mleczne

IV. Srodki spożywcze i odżywcze. 1) Przetwory mięsne. 2) Przetwory mleczne. 3) Przetwory mączne. 4) Konserwy. 5) Napoje alkoholiczne. 6) Napoje bez

\section{przędzalniczy}

do obróbki wszelkich metali, trwalsze 4 do 5 razy od szmerglowych lub korundowych i działajace kilka razy szybciej i dokładniej oraz Plótno, Papier, Proszek, Oselki, Tasmę do tre rd przęzalniczych i inne wyroby z Karborundum. przewrższaia-

przy czyichś szczerych chęciach

stów ze swej strony również dołożyć cegielkię, które wrięte razem przy szczerych chęciach ludzi dobrej woli, byé może wkrótce, utworza fundament nowego gmachu jednej $z$ najsympatyezniejşzych instytucyj naszego miasta. Vivat sequens!

\section{psycho-fizyologia}

III. Nanka lekarska: 1) Anatomia. 2) Fizyologia. 3) Psycho-fizyologia. 4) Patologia : a) ogólna, b) szczegółowa. 5) Środki farmaceutyczne. 6) Seroterapia i serodiagnostyka, organoterapia. 7) Narzędzia chirurgiczne (ginekologia, oknlistyka, laryngologis, dentystyka etc.). 8) Elektroterapia i elektrodiagnoza (Roentgen).

IV. Środki spoźywcze i odżywcze. 1) Przetwory mięsne. 2) Przetwory mleczne. 3) Przetwory ms̨czne. 4) Konserwy. 5) Napoje alkoholiczne. 6) Napoje bez

\section{Pullman}

król hotelowych przedsiębiorstw, jak Flagler, król parceli budowlanych, jak Astor, król wagonów, jak Pullman, król prasy, jak Pulitzer, i wielu, wielu innych. 
\#R

radca sądowy

\section{Telegraficzn日 i teleffoniczne wiadomości „Nowej Reformy",}

Wiedeh, 3 marca. Wiener Ztg. ogłasza: Minister sprawiedliwości przeniósł radce sądowego i naczelnika sadu powiatowego Aleksandra $\mathrm{Z}_{\mathrm{g}} \mathrm{O}^{-}$ de -Fijalkiewicza w Zatorze do Kęt i zamianowal sędziami powiatowymi: sekretarza sqdowego w Tyczynie Romana R y barkiegol

rażąca niesprawiedliwość

wszyscy odežuli wo korespondenejach rażącą niesprawiedliwość, powtóre, że nasi współobywatele wyznania ewangelickiego tu się porodzili i tu ich sympatje wiąża, sa to nasi dobrzy towarzysze w stowarzysze-

receptura

Cheąc wstạpić do apteki naleźy przedewszystkiem wykazać się șwiadectwem $\mathrm{z}$ ukoniezonej $\mathrm{z}$ dobrym postępem 6 klasy gimnazyalnej i potrzeba mieć jaki taki mająteczek. Praktyka w aptece trwa przez 3 lata, w którym to ezasie otrzymuje uczeń wikt $\mathrm{i}$ pomieszkanie, lub odpowiednie za to wynagrodzenie. Po skoniczonej 3-letniej praktyce składa on egzamin z chemii, nauk przyrodniczych, towaroznawstwa, znajomości receptury i laboratoryum, poczem zostaje asystentem (podaptekarzem). Na mocy tego egzaminu ma asystent prawo do jednorocznej służby wojskowej i zobowiązany jest zapisać się $\mathrm{z}$ nadchodzącym pażdziernikiem na 2-letni kurs farmacyi na wszechnicy, jeżeli chce wogóle zostać kiedys samoistnym aptekarzem, lub tylko zarzạdeą albo dzierżaweą apteki. 
w krązeniu, tem samem działamy i na poszezególne objawy $\mathrm{i}$ je usuwamy. Przechodząe kolejno wszystkie objawy i podająe na to środki, mimowolnie autor masi siẹ powtarzać, a tego do zalet książi policzyć nie mozna. Zwłaszeza co do receptury musze zrobić zarzut, ze jej jest za wielo i to recept mało różniących się od siebie, a zapełniających niepotrzebnie całe stronice książki. Teź same recepty pouvtarzają sie przy rozmaitych objawach sercowych i niemal przy ka. zdym objawie zmajdujemy powtarmajace się recepty juz to

- To mnie dziwi, - zauwazył Krystyn, - przecię farmacya jest tak ciekawa.

- Naturalnie! potwierdził Sommer, jakkolwiek nie da się zaprzeczyć, ze sama receptira jest nieco monotonną, a ze w dxisiejszych aptekach przewaznie tylko recepty się odrabiają, więc taka jednostajna maszynowa praca rychło męczy i aptekarz w koricu znienawidza swoje zajęcie.

W ten sposób Krystyn prędko posiadł wszystkie tajniki receptury, Gdy juz miał rok skończony praktyki, Sommer zapytal go pewnego dnia:

- Czy , stary* nie mówił panu jeszcze, ze wkrólce zacznie razem z panem w laboratoryum pracować?

- Owszem, właśnie niedawno wspominał coś o tem, - odparł Krystyn.

\section{referat}

kol. Kurkiewicz. W przemowie swej zastrzegał się przeciw temu, aby właściciele aptek nie użyli swej przewagi wtedy, gdy opinie współpracowników będą przeciwne i aby ta dyskusya toczyła się na prawach równych bez obawy, ze który za śmielsze słowo może ucierpieć. W dalszym ciągı kol. M. Kulak przemawiał, aby kołedzy współpracownicy dyskutowali hez zúłei, spokojnie. golyz właścicielom aptek zarówno jak i współpracownikom jednako zależeć powinno na utrwaleniu stanowiska i bytu zawodu.

Poniewaź do pozylywnej pracy na pierwszem posiclzeniu przystapić nie moz̀na było, przelo po dość ożywionej dyskusyi nad kwestyami drobniejszego znaczenia, przystapiono do rozebrania referatów. Postanowiono, ahy każdy referat mial dwóch

robak obły

Ten ostatni w niektórych razach róžnicuje się w błonę falującą, pomocną przy ruchach plemnika, lub teź czasem redukuje się (np. u robaków obłych) do niewyraźnie skonturowanej brylki plazmatycznej, zdolnej do wykonywania ruchów pełzakowatych. 


\section{rozbiór chemiczny}

Nagrodzone zostaly zlotym medalem na Warzzawskiej Wystawie Hygienieznej 1896 r., a rozbiór tychże chemiezno-lekarski, dokonany w laboratorjum Szpitali Warszawskich za Nr. 1435 przez pana Doktora Medyeyny, Leona Nenckiego, wykazat nastepujący rezultat, ktory w doslownem brzmieniu poniżej zamieszczamy :

Kakao i czekolada firmy Riese \& Piotrowski w Warszawie, nalesłane przez Zarząd Wystawie Hygienieznej, przy rozbiorze chemieznym daly wyniki nastẹpujące:

\section{A) Kakao w proszku.}

rozpisać konkurs na coś

Rozpisanoby najpierw konkurs na program ogólny, zgodny z planem naukowym. Dopiero po przyjęcia programu przez ad hoc zwolaną ankietę, rozpisanoby drugi konkurs na książki.

\section{rumak stalowy}

polină nie malo wymagato zręezności,-dojeżdźa się do Annopola pierwsze lwie wiorsty po drodze polnej bardzo cięzkiej i piasczystej, a dalej dopiero szosą drugor\%ęuną, rozpoczynającą się w otwartem polu.

Wypoczęci należycie, po opatızeniu maszyn, gdy znaleźliśmy się znowu na grzbietach a właściwie siodelkach swych rumatków stalowych, z prawdziwą rozkosza, ra-

\section{\#S}

\section{samopomoc koleżeńska}

\section{Kasa chorych}

dla wspólpracownikow aptekarskich prey Galicyj. Tow. farmac. „Unitas" w Krakowie jedyna instytucya samopomocy koleżeńskiej w razie choroby; zatwierdzona przez Wys. c. k. Ministerstwo i zostaj̧̨ca pod kontrolą Wys. Władz ubezpiecza swych ezłonków pod warunkami korzystniejszymi, jak wszelkie inne tego rodzaju zakłady.

Przy tej sposolnności zwraca się uwage WP. Członków, iž należy dokładnie przestrzegać formalnosci statuten okresjonych. allowiem wspomniana Kasa nie jest zakładem zapomogo. wym, ale oprarta na zasadzie ustawy paústwowej ma zobowiązania li tylko w razie udowodnio. nej (swiadectwem lekarskiem) oblozinej choroby lub zupelnej niezdolnosci zarobkowania. 
sąd doraźny

Marszalek krajowy w najbližszym czasie zwoła ankietę wszystkich prezesów rad powiatowych, celem naradzenia się nad sytuacyą w kraju, której wyrazem jest zaprowadzenie sądów doraźnych i stanu wyjątkowego.

sekcyjny

wą dźny w Wiedniu, wezmą jăko réprezentanci rzg̨du udzial: szef sekcyjny Stummer i radca mi nisteryalny Dr Kasy.

serodiagnostyka

6) Dezinfekcya. 7) Gimnastyka lecznicza i t. d. 8) Odzienie.

III. Nanka lekarska: 1) Anatomia. 2) Fizyologia. 3) Psycho-fizyologia. 4) Patologia : a) ogólna, b) szczegółowa. 5) Środki farmaceutyczne. 6) Seroterapia i serodiagnostyka, organoterapia. 7) Narzędzia chirurgiczne (ginekologia, oknlistyka, laryngologia, dentystyks etc.). 8) Elektroterapia i elektrodiagnoza (Roentgen).

IV. Środki spožywcze i odżywcze. 1) Przetwory mięsne. 2) Przetwory mleczne. 3) Przetwory mączne. 4) Konserwy. 5) Napoje alkoholiczne. 6) Napoje bez

składownik

W roku 1897 to jest od 1 styeznia do 31 gruania obrót tytoniowy wynosia $39075 \mathrm{z}$. 22 et., zysk $\mathrm{z}$ drobnej sprzedaży wynosil $\mathrm{w}$ tym ezasie 253 zł. 64 et., zaś obrót w stemplach, listach przewozowych i blankietach wekslowych wynosil $6512 \mathrm{zl} .91$ et, od sprzedaży tych znaczków wartościowych będzie pobieral składownik pół procent. 
służba wojskowa

Cheąc wstąpic do apteki naleźy przedewszystkiem wykazać się șwiadectwem $\mathrm{z}$ ukoniczonej $\mathrm{z}$ dobrym postępem 6 klasy gimnazyalnej i potrzeba mieć jaki taki mająteczek. Praktyka w aptece trwa przez 3 lata, w którym to czasie otrzymuje uczeń wikt i pomieszkanie, lub odpowiednie za to wynagrodzenie. Po skoniczonej 3-letniej praktyce składa on egzamin z chemii, nauk przyrodniczych, towaroznawstwa, znajomości receptury i laboratoryum, poczem zostaje asystentem (podaptekarzem). Na mocy tego egzaminu ma asystent prawo do jednorocznej słužby wojskowej $\mathrm{i}$ zobowiązany jest zapisać się z nadchodzącym pażdziernikiem na 2-letni kurs farmacyi na wszechnicy, jeżeli ehce wogóle zostać kiedy§ samoistnym aptekarzem, lub tylko zarzạdeą albo dzierżaweą apteki.

sodowo-słony

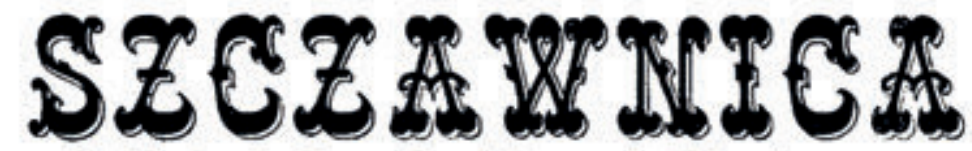

\section{Zakład zdrojowo-kąpiolowy i klimatyczny.}

Nsjgilniejsze szezswy sodowo-slone I zelaziste, skuteczne w poezątkach suchot, po zapaleniu plue, w astmir, w niı żytarh oskrzpli i krtani, w cierpieniach zołądka, kiszek, wątroby i bemoroidaluysb, przy wytwąrzanin się kamieni w peeherzu i nerkach, w chorobach kobieych, w niedekrewaosei,

spełznięcie czegoś na niczem

Fiasco (czytaj fiasko), z włoskiego, znaczy zupelne niepowodzenie, spelznięcie powziętego zamiaru na niczem, porażka.

stan spoczynku

Kanceliata sądow $\mathrm{y}$ w Nadwórnoj Jozef Kutschera przy przejściu w atan spoczynku otrzymal tytul i charakter oficyala II klagy.।

Ankieta w kwestyl żydów galleyjskich zwoYaną zostala do Wiednia przez tamtejezze Stowarzy- 
stan wyjątkowy

Ciągle stan wyjątkowy. - Ankieta szkolua. - Sekcya szkolna i opinia publiczna. - Zwycięztwo demokratów. - Zmartwychwstanie Życia. - Wystawa chryzantemów. - Ogrodnictwo.

stary kawaler

Jeżeli ankieta „starych kawalerów", jest już u-
kończoną, pozwól Szanowna Redakcjo w imię
sprawiedliwości i sluszności na ankietę zobiet,
byśsmy mogly zabrać glos w tej sprawie, gdyż
wiele a wiele rzeczy bylo tam dziwnie przed-

Marszałek krajowy w najblizszzym czasie zwola ankietę wszystkich prezesów rad powiatowych, celem naradzenis się nad sytuacyą w kraju, której wyrazem jest zaprowadzenie sądów doraźnych i stanu wyjątkowego. .

stawiać pytanie, ...

stwo? Nareszcie, wzywa ankieta do podawania projektów reformy i stawia pomiędzy innemi pytanie, w jaki sposób naleźaloby uzupełnic plan nauk i sposób wychowania, aby szkoly realne i gimnazyalne czynily zadose potrzebom społeczeństwa.

stopa procentowa

Bauk angielski podw yższyl stopę procentową ns 3 procent. 


\section{strefa klimatyczna}

Kwestye powyższe przedstawil prof. Janczewski $w$ formalnych wnioskach, ktoce zostały przez snkietę przyjęte jednomyślnie. Przemówienie dr. Szyszylowicza spowodowalo ostateczne zalstwierin sprawy zajmującej ankietę - a mianowicie przez wybór komisyi z grosa znanyeh pomolog $6 \mathrm{w}$ dls kazdej strefy klimatycznej, celem doboru 0 wocow najlepiej odpowiadających warunkom naszego kraju. W skład takich komisyj we-

\section{szkło apteczne}

Triturat o hydrarisyri euin Ianolino an part. aequales, kilo $3 \mathrm{zkr} .90 \mathrm{ct}$

Utrzymuje na składzie ważniejsze materyaly apteczne, hegary blaszane i szklane,
apteczne, termometry maksymalne, kąpielowe i ścienne, flaszeczki-kroplomierze,
lacze, pęzelki, pezle do gardla, worki na lód, wstrzykawki szklane cate, lub
awach cynowych albo kauczukowych, alkoholometry, lampki spirytusowe, knlbki
$i$ wiele innych utensyliów zawartych w cennlku.

\section{szkoła realna}

stw0? Nareszcie, wzywa ankieta do podawania projektów reformy i stawia pomiędzy innemi pytanie, w jaki sposób należaloby uzupełnic plan nauk i sposób wychowania, aby szkoly realue i gimnazyalne czyniły zadose potrzebom społeczeństwa.

szkoła średnia

P. Rotter wnosi uchwalenie potrzeby reformy szkó średnich, któraby na podstawie szkoly wspol nej, czy tez wprowadzenia stosownej bifurkacyi w szkolach wyzszych, ułatwila abitaryentom szkoly średniej wybör kiernnkn technicznego lub uniwersyteckiego. Wydział krajowy powolać ma w porozumienin z Radą szkolną krajows̨ ankietę, w celu ustanowienia plann stosownej reformy szkol érednich. Wreszcie Sejm wyrazic ma potrzebę wydania nstawy pahstwowej, określającej 
szkoła wyższa

P. Rotter wnosi uchwalenie potrzeby reformy szkol średnich, któraby na podstawie szkoly wspolnej, czy tez wprowadzenia stosownej bifurkacyi w szkolach wyzszych, ułatwila abituryentom szkoly średniej wybór kiernnkn technicznego lub uniwersyteckiego. Wydział krajowy powolać ma w porozumienin z Radą szkolną krajow̧̨ ankietę, w celu ustanowienia plann stosownej reformy szkol ́rednich. Wreszcie Sejm wyrazic ma potrzebę wydania nstawy pałstwowej, określającej

szmerglowy

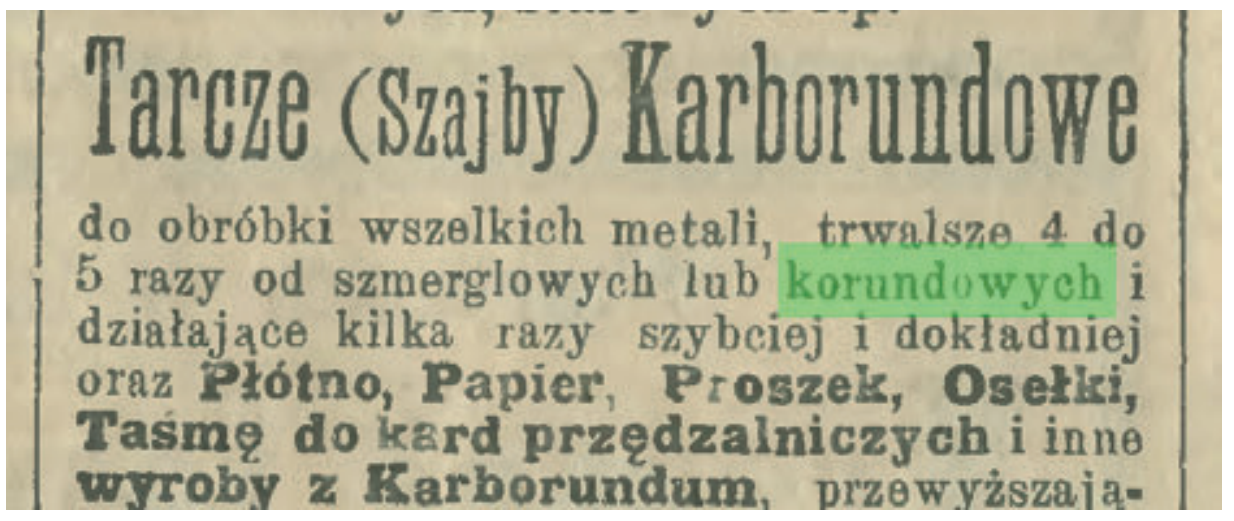

szmirgiel
wiające domieszki. Jest po dyamencie najtwardszym minerałem. Niektóre ka- mienie szlachetne są zabarwionym ko- rundem, i tak korund niebieski nazywa się szafirem; korund pięknie czer- wony $\mathrm{rubine} \mathrm{m}$. Nieczysty korund na- zywa się szmirglem i w stanie proszku lub ziarnek używa się do szli- fowania i polerowania kamieni, me- tali i t. p. 
\#Ś

środki farmaceutyczne

III. Nanka lekarska: 1) Anatomia. 2) Fizyologia. 3) Psycho-fizyologia. 4) Patologia : a) ogólna, b) szczegółowa. 5) Srodki farmaceutyczne. 6) Seroterapia i serodiagnostyka, organoterapia. 7) Narzędzia chirurgiczne (ginekologia, oknlistyka, laryngologia, dentystyka etc.). 8) Elektroterapia i elektrodiagnoza (Koentgen).

świadectwo lekarskie

\section{Kasa chorych}

dla współpracowników aptekarskich przy Galicyj. Tow. farmac. „Unitas" w Krakowie jedyna instytucya samopomocy koleżeńskiej w razie choroby; zatwierdzona przez Wys. c. k. Mlinisterstwo i zostajn̨ca pod kontrolą Wys. Władz ubezpiecza swych ezłonkỏw pod warunkami korzystniejszymi, jak wszelkie inne tego rodzaju zakłady.

Przy tej sposolnności zwraca się uwage WP. Członków, iz naležy dokładnie przestrzegać formalnosci statuten okreslonych. albowiem wspomniana Kasa uie jest zakładem zapomogo. wym, ale oparta na zasadzie ustawy paústwowej ma zobowiązania li tylko $w$ razie udowodnio. nej (swiadectwem lekarskiem) oblozinej choroby lub zupelnej niezdolnosci zarobkowania.

\# T

teoretyczno-doświadczalny

2) Pan J. Morozewicz znkomunikowal referat: ${ }_{n} 0$ skalach korundowych".

Studya teoretyczno-doświadczalne przeprowadzone niedawno przez referenta wykazaly, że glink̊ z nadzwyczajną latwością, wydziela się ze stopów krzemionkowych w postaci krystalicz- 
tkanka łączna
U tkankowców najniższych, jako to gąbek, polipów, wytwarzanie jaj i plemników nie jest przywiazzane do żadnego okreslonego organu: u gąbek powstają one w rozsianych komór- kach tkanki łącznej, wypelniających cały ustrój. U Hydroidow elementy plciowe mo-

tkankowiec
- U tkankowców najniższych, jako to gąbek, polipów, wytwarzanie jaj i plemników nie jest przywiazane do żadnego okreslonego organu: u gąbek powstaja one w rozsianych komór- kach tkanki łųcznej, wypelniających caly ustrój. U Hydroidow elementy plciowe mo-

\section{towaroznawstwo}

Cheạc wstạpić do apteki naleźy przedewszystkiem wykazać się șiadeetwem $\mathrm{z}$ ukoniczonej $\mathrm{z}$ dobrym postẹpem 6 klasy gimnazyalnej $\mathrm{i}$ potrzeba mieć jaki taki mająteczek. Praktyka w aptece trwa przez 3 lata, w którym to ezasie otrzymuje uczen wikt $\mathrm{i}$ pomieszkanie, lub odpowiednie za to wynagrodzenie. Po skoniczonej 3-letniej praktyce składa on egzamin z chemii, nauk przyrodniczych, towaroznawstwa, znajomości receptury i laboratoryum, poczem zostaje asystentem (podaptekarzem). Na mocy tego egzaminu ma asystent prawo do jednorocznej słužby wojskowej i zobowiązany jest zapisać się z nadchodzącym pażdziernikiem na 2-letni kurs farmacyi na wszechnicy, jeżeli chce wogóle zostać kiedys samoistnym aptekarzem, lub tylko zarzạdeą albo dzierżaweą apteki. 
tu i owdzie

dowała jakiś czas komisya w Akademii Umiejętności krakowskiej, a gdy wynik jej narad ogloszono, ocenil je zmarly właśnie radca dworu dr. Zygmunt Samolewicz calkiem spokojnic i przedmiotowo i wykazał niefortunnośc pomyslu. Prawie równocześnie radzono w komisyi lwowskiej o szkole jerlnolitej, o czem p. dyrektor Gerstmann na ankiecie mówil, i obmyślono jej program. Rzecz jednak poszla w zapomnienie, ale znowu tu i owdzie pojawiały się w pismach i dysputach niekorzystne krytyki dzisiejszego systemu, podnoszace rzekomo wyższe zalety naszych wlasnych polskich szkól dawniejszych.

\#U

uczestniczka

Przedsiębiorców - jakkolwiek zaproszonych było wielu - stawiło się zalodwio 20 , zo sfor robotniczych zaś wzięlo udzial 189 kobiøt i 59 mężczyzn. Ankieta miala wiele klopotu, zanim się dowiedziala od każdej $\mathrm{z}$ uczestniezek cokolwiek o stosunkach pracowni, w których byly zatrudnione. To jednak, co za pomoca krzyżowego ognia pytań wydobyto, bylo wielce pouczającem. Wiadomo, że w wielu

udar sercowy

Znakomity traglk wloski, Cezar Rossi, zmarl w Bari na udar sercowy w 68 r. życia. 


\section{\#W}

we

szcze dokladal. Jaka to szkoda, rzekł Weigel, że Matejko nie umie ani po francusku, ani po niemiecku; na wiosnę bylem \% nim razem we Wiedniu; jak go tam przyjmowali? ma on u ministra wielkie znaczenie, a u innyeh w Wiedniu wielkie poważanie; gdyśmy sta-

wikt i pomieszkanie

Cheąc wstąpié do apteki naleźy przedewszystkiem wykazać się łwiadeetwem $\mathrm{z}$ ukoniczonej $\mathrm{z}$ dobrym postẹpem 6 klasy gimnazyalnej i potrzeba mieć jaki taki mająteczek. Praktyka w aptece trwa przez 3 lata, w którym to czasie otrzymuje uczen wikt i pomieszkanie, lub odpowiednie za to wynagrodzenie. Po skoficzonej 3-letniej praktyce składa on egzamin z chemii, nauk przyrodniczych, towaroznawstwa, znajomosci receptury i laboratoryum, poczem zostaje asystentem (podaptekarzem). Na mocy tego egzaminu ma asystent prawo do jednorocznej służby wojskowej $\mathrm{i}$ zobowiązany jest zapisać się $\%$ nadchodzącym pażdziernikiem na 2-letni kurs farmacyi un wszechnicy, jeżeli ehce wogóle zostać kiedys samoistnym aptekarzem, lub tylko zarządeą albo dzierżawea apteki.

winda osobowa

Stary renomowany hotel fumiling nowouızadzony. 200 pokojów goficinnyes od 1 fiorena poezawszy, łącznie $z$ ushuga i swiattem. C. K. Biuro tolegraficzne i telefonow nam.ejs n. Eorzystne polozenie dla zwiedzających vystawe jutileuszowi. Ceny niepodwy sszone. Jworce koiejowe i przystanki parowcót w wajbliz. szem easiedztwie. Tramwaje $\mathrm{f}$ omnibusy hotelowe we ws ystkich kierunkach. Znakomita restaurauja, winda osobowa. F. M. MAYER Wlasciciol.

wotywa składkowa

+ Jutro, t. J. w sobote, d. 6 siorp-

nia, o g. 9 r., w kośolele Archlka. tedralnym Sw, Jana, ozprawiona

zostanie wotywa składkowa na intencje współpracowników fapryki W-go W. Gebethnera, -3357- 


\section{współpracownik}

kol. Kurkiewicz. W przemowie swej zastrzegal się przeciw temu, aby właściciele aptek nie użyli swej przewagi wtedy, gdy opinie współpracowników będą przeciwne i aby ta dyskusya toczyła się na prawach równych bez obawy, ze który za śmielsze słowo moze ucjerpiec. W dalszym ciagı kol. M. Kulak przemawiar, aby koledzy współpracownicy dyskntowali hez zółci, spokojnie. gulyz wiaścicielom aptek zaròwno jak i współpracownikom jednako zalełect powinno na utrwaleniu stanowiska i bytu zawodu.

\section{wstępniak}

Eis... Teodor Wolski, Hnfnagel, Dawid Klaczko, St. Wojno, II. Blnmensohn, B. i Z. Hanicey, Dr. Z. Kusociński, I. Agafonoff, Czeslaw Meduski, Antoni Majewski, St. Roland, K. Rykowski, bracis Ch. A. i Sz. Folman, Leopold Jarkowski, Stanisław Hempel, Tadeusz Oryng, R. Eywik, A. B. C., Leon Salcwasser, Wstepniak $\mathrm{z}$ gimnazum III-go, Antoni Korytyniski, Narcyz Wardynski, W. S. Konatkiewicz, Aleksanber König, I. Kowalewski, Stanisław Plater, Henryk Wal..., A. Szumski, student Jan B, A. Plerwocha, Juljan Lukree, Słranisław Hrvniewicz. J. Crnarski. Aleksander Ekerkunst,

wstrzykawka

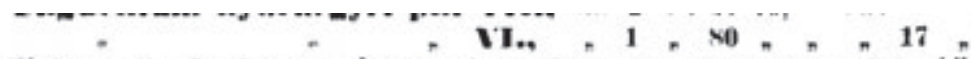

Trituratio hydrarygri cum Innolino an part. aequales, kilo 3 zkr. $90 \mathrm{et}$.

$n$

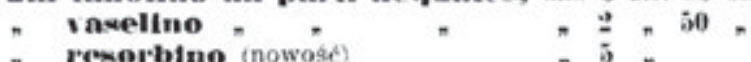

Utrzymuje na składzie ważiejsze materyaly apteczne, hegary blaszane i szklane, szk io apteczne, termometry maksymalne, kąpielowe i ścienne, flaszeczki-kroplomierze, zakraplacze, p̧̧zelki, pęzle do gardla, worki na lód, wstrzykawki szklane całe, lub w oprawach cynowych albo kauczukowych, alkoholometry, lampki spirytusowe, knlbki szklane $i$ wiele innych utensyliów zawartych w cennlku.

\section{wszechnica}

Cheąc wstąpić do apteki naleźy przedewszystkiem wykazać się swiadectwem $z$ ukończonej $\mathrm{z}$ dobrym postępem 6 klasy gimnazyalnej i potrzeba mieć jaki taki mająteczek. Praktyka w aptece trwa przez 3 lata, w którym to czasie otrzymuje uczeń wikt $\mathbf{i}$ pomieszkanie, lub odpowiednie za to wynagrodzenie. Po skoniczonej 3-letniej praktyce składa on egzamin z chemii, nauk przyrodniczych, towaroznawstwa, znajomości receptury i laboratoryum, poczem zostaje asystentem (podaptekarzem). Na mocy tego egzaminu ma asystent prawo do jednorocznej słužby wojskowej i zobowiązany jest zapisać się z nadchodzącym pażdziernikiem na 2-letni kurs farmacyi na wszechnicy, jeżeli ehce wogóle zostać kiedys samoistnym aptekarzem, lub tylko zarzạdcą albo dzierżaweą apteki. 
wyścigowiec

zaslużył na drugą nagrodę. Jeden zaś ze znanych wyścigoweów wpadł na niezbyt odpowiedni lecz dosyé oryginalny pomysł: kostjum miał wyścigowy, maszynę okręconą różnokolorową materją a nad kierownikiem łuk, z pizodu którego był napis „amator“ $\mathrm{z}$ drugiej zaś strony ... bierze tylko pieniądze", które mialy imitować powieszone rozmaitej wielkości woreezki; w ramie widnial napis: „patent na amatora“.

\section{\#Z}

zadać komuś-czemuś klęskę

natora Davisa, "przyjaciela Mac-Kin-

1)ya, ze Stapy Zjednoczone bedą roz. strzygajaca potega na Ocenie Spolsoj. i nym. Zdaje sie, że chea one zostac ta potęga rozstrzygajaca na oba see. anach. potychezas Europa musiala sie liczyé z Unija tylko pod względem handlowym. Spletalan amerykański zadal rolnictinu i przemysłowi euroneiskiemu iuż nieiedna Kleske.

zakład kąpielowy

Stary renomowany hotel familisy nowourzdzony. 200 pokojów gofeinnye) od 1 florena poczawbzy, kęcznie $z$ ushuga i swiattem. C. K. hiuro telegraficzne $i$ telefonów na miejs a. Korzystne polozenio dla zwiedxających wystave jubfleu. szowa. Ceny niepodwyiszone. Sworce koiejowe i przystanki parowców w najbliz. szom kasiedztwie. Tramwaje i omnibusy hotelowe we wsystkich kiernnkach. Znako. mita restauraja, winda osobowa. 2. M. MAYER Wiasciciol.

GLA ZAKKAQÓW KĄPELOWYEH i DLA LETMHKÓW, Lawn-Tenn s, Krokiety. Badminton, Cricket, Boccis, Gra to Zabs, Rakiets, Wolanty,_Kregle 


\section{zakład zapomogowy}

\section{Kasa chorych}

dla wspólpracowników aptekarskich przy Galicyj. Tow. farmac. „Unitas" w Krakowie jedyna instytucya samopomocy koleżeńskiej w razie choroby; zatwierdzona przez Wys, c. k. Hinisterstwo i zostaj̧̨ca pod kontrolą Wys. Władz ubezpiecza swych ezłonków pod warunkami korzystniejszymi, jak wszelkie inne tego rodzaju zakłady.

Przy tej sposolnności zwraca siẹ uwage WP. Członków, iž należy dokładnie przestrzegaé formalnosci statutem okreilonych. allowiem wspomniana Kasa uie jest zakładem zapomogowym, ale opauta na zasadzie ustawy paústwowej ma zobowiąania li tylko w razie udowodnio. nej (swiadectwem lekarskiem) oblozinej choroby lub zupetnej niezdolnosci zarobkowania.

\section{zakomunikować}

\section{2) Pan J. Morozewicz znkomunikowal refe-} rat: ${ }_{n} 0$ skalach korundowych".

Studya teoretyczno-doświadczalne przeprowadzone niedawno przez referen'a wykazaly, że glinkn z nadzwyczajną latwością, wydziela siẹ ze stopów krzemionkowych w postaci krystalicz-

\section{zakraplacz}

Trituratie hydrarkgri eum Innolino an part. aequales, kilo 3 atr. $90 \mathrm{ct}$

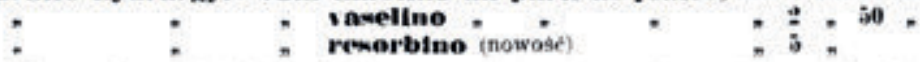

Utrzymuje na składzie ważniejsze materyaly apteczne, hegary blaszane i szklant, szklo apteezne, termometry maksymalne, kapielowe $\mathrm{i}$ Seienne, faszeexki-kroplomierze, zakraplacze, perzelki, pezle do gardla, worki na 16d, wstrzykawki szklane cale, lub w oprawach cynowyeh albo kauczukowych, alkoholometry, lampki spirytusowe, knlbki szklane $i$ wiele lanych utensyliów zawrartych w cennlku.

2 W Wielkim słowniku języka polskiego PAN w Krakowie, dostępnym (vidi 13.7.2020) na stronie internetowej www.wsjp.pl pod zakładką CHRONOLOGIZACJA znajdowała się następująca informacja:

SJPDun: zakommunikować

ISJP

PSWP

USJP

Pas

SIJPArct

SJPDor

SJPWar

Nie podajemy rozwiązania skrótów wyliczonych „w słupku” słowników; są one do natychmiastowego odczytania na tejże stronie www.wsjp.pl. Zwracamy jedynie uwagę, że „Pas” odsyła do słownika języka Jana Chryzostoma Paska (1636-ok.1701); autor ten nie znał ani wyrazu zakomunikować, ani wyrazu zakommunikować. Jeszcze jedno: „Słownik Dunaja” (na liście powyższych skrótów to „SJPDun”) nie ma hasła zakommunikować, lecz wyłącznie zakomunikować. 
załączka

\section{(Do artykutu 6 umow y).}

$\S 2$. Listy przewozowe międzynarodowe wygotowywać należy na blankietach, których wzór podaje załączka $2^{1}$ ). Blankiety te powinny być wydrukowane do posylek zwyezajnych na białym, do pospiesznych na eiemno-ró-

zapałki fosforowe

\section{Zakaz. Rząd szwajcarsti zakazal wyrobu za-} palek fosforowych.

zblazowany

Hotel "Bristol" stal "sį̨ osobliwością wiedeńskq godnq zwidzenis i nawet najbardziej zblazowani wojazerowie, przyzwyczajeni do najwspenialszyoh hotelow angielskioh i amerykańskich przyznaj

zdrojowo-kąpielowy

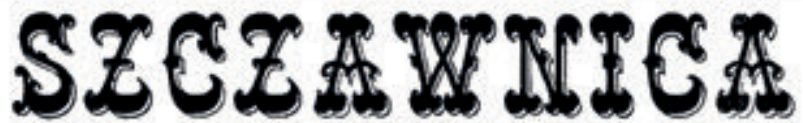

\section{Zakład zdrojowo-kąpielowy i blimatyczny.}

Najsilniejsue szezawy sodowo-slone 1 zelazlste, skuteczat w poesątkach suchot, po zapalebiu plue, w astmir, w ai zytarh oskrurli i krtani, w cier. pieniach tolądra, kiszek, wątroby i bemoroidslay b, przy wytwąrzanio się kamiesi w pęehrran i nerkach, w ehorobach kobieyeh, w niedekrewooded,

zegarek kieszonkowy

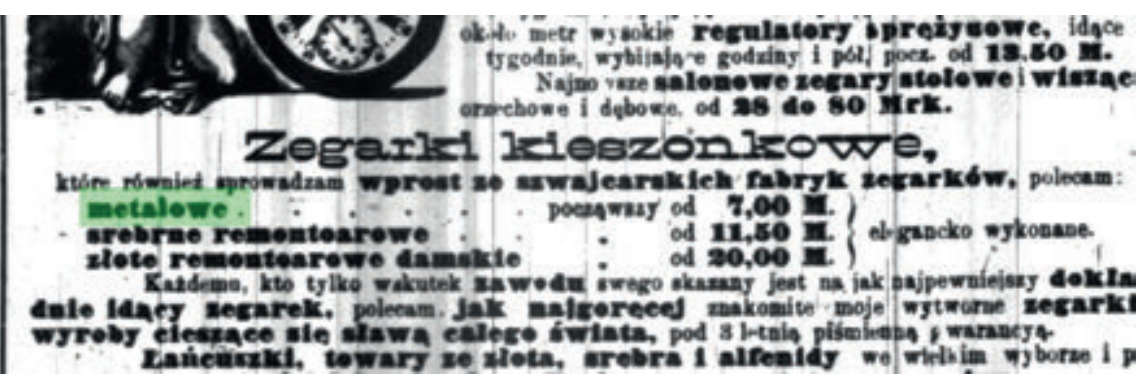


znaczek wartościowy

W roku 1897 to jest od 1 styeania do 31 grudnia obrót tytoniowy wynosid $39075 \mathrm{z}$. 22 et., zysk z drobnej sprzedaży wynosił w tym czasie 253 zł. 64 ct., zaś obrót w stemplach, listach przewozowych i blankietach wekslowych wynosil 6512 zl. 91 et, od sprzedaży tyeh znaczków wartościowyeh będzie pobieral składownik pól procent.

zrobić fiasko

prass bawarska. Z okazyi otwaroia $\mathbf{z}$ Monaohinm wystawy maszyn odbywale się uroczystódé z pochodami przez miasto ns oześć księoia rejents. Uroozystośd ta zrobila poniekqd fissko. Upamiętnil ją przytem epizod jedyny $w$ swoim rodzsju. Oddzielnq trybune przestrone i okszale, z pulpitami do pisanis itd. wrniesiono dle driennikarzy. Otó kiedy dziennikarze zajęli miejsos, jakis ozlonek ko-?

zwołać ankietę
asunięcia, a w szozególnośor domagajy̨o się. aby ciala antonomiczno sprawą t̨ి się zajęly, znalazły oddżwię $\mathbf{w}$ calej prasie, Jeduo z pism krakowskich doniosla już nawet, iz marszaīok krajowy taką ankietę zwolaó po. stanowil - o czem nam atoli do tej chwili jeszeze nic autentyoznogo nie wiadomo
Nadeszly dzis do Lwowa Wieniec ks. 
Przymiotniki ogromny, wielki nie są tu nadużyciem. Jeśli ktoś kliknie w sieciowym NFJP np. na hasło hotel czy hotelowy, to znajdzie tam tylko po jednym fotocytacie, tymczasem w zasobach niejawnych NFJP takich fotopoświadczeń na owe wyrazy mamy dziesiątki. W wypadku wielu innych haseł odnotowanych w sieciowym NFJP fotopoświadczeń zmagazynowanych, niedostępnych użytkownikom, są setki, a niekiedy wręcz nie setki, lecz setki tysięcy, a nawet miliony (tak!) fotocytatów. To dowód naszej mocy badawczej. Epoka ,bigdatowa” w leksykografii języka polskiego została otwarta.

Autorzy

[To praca] wybitnych polskich językoznawców, teoretyków i praktyków nowoczesnej leksykografii polskiej, korpusologów, twórców oryginalnych narzędzi, aparatu badawczego i terminologicznego w polskiej leksykografii ,globalnej”, chronologizacyjnej i fotokorpusologii, a przede wszystkim skrzętnych dokumentalistów zasobów polszczyzny, rejestratorów neoleksyki, dociekliwych weryfikatorów polskiego słownictwa i redaktorów jego źródłosłowów (w obrębie konkretnych i sprawdzonych już przez nich działań chronologizacyjnych). [...] Sylwetek tych językoznawców nie trzeba przedstawiać, bowiem ich dokonania są dobrze znane i spotykają się z wielkim uznaniem, również za granicą.

Z recenzji prof. Katarzyny Wojan

Monografia [...] dokumentuje przebieg prac nad przedsięwzięciem unikatowym nie tylko w skali kraju, a mianowicie nad Narodowym Fotokorpusem Języka Polskiego. Korpus ten gromadzi poświadczenia cytatowe dla 250 tys. haseł słownikowych obejmujących stulecie 1901-2000. Jan Wawrzyńczyk i Piotr Wierzchoń omówili stopień zaawansowania prac po upływie sześciu lat od ich podjęcia, klarownie przedstawiając cele swojej inicjatywy i metodologiczne podstawy projektu oraz dokonując wyczerpującego przeglądu dorobku ekscerpcyjnego dla polszczyzny XX wieku (w postaci kompletnego spisu bibliograficznego) ze wskazaniem na znaczenie nowych prac leksykograficznych dla dogłębnego poznawania polszczyzny. Autorzy przedstawili też strukturę tworzonego NFJP, poruszyli problem słownictwa obecnego w fotodokumentach, ale w hasłowniku Korpusu niewidocznego, [...] zaprezentowali część owej leksyki nazwanej latentną. Trzon recenzowanej książki stanowi wybór fotomateriałów z jednego tylko 1898 roku. [...] Monografia została napisana wzorcową polszczyzną, piękną, przebogatą, świeżą.

$\mathrm{Z}$ recenzji prof. Jolanty Mędelskiej-Guz 